\title{
ANÁLISE ECONÔMICA DE SISTEMAS ALTERNATIVOS DE PRODUÇÃO DE TILÁPIAS EM TANQUES REDE PARA DIFERENTES MERCADOS
}

\section{DANIEL YOKOYAMA SONODA}

\author{
Dissertação apresentada à Escola Superior de \\ Agricultura "Luiz de Queiroz", Universidade de São \\ Paulo, para obtenção do título de Mestre em Ciências, \\ Área de Concentração: Economia Aplicada.
}

P I R A C I C A B A

Estado de São Paulo - Brasil

Outubro - 2002 


\title{
ANÁLISE ECONÔMICA DE SISTEMAS ALTERNATIVOS DE PRODUÇÃO DE TILÁPIAS EM TANQUES REDE PARA DIFERENTES MERCADOS
}

\section{DANIEL YOKOYAMA SONODA}

\author{
Engenheiro Agrônomo
}

Orientador: Prof. Dr. RICARDO SHIROTA

\begin{abstract}
Dissertação apresentada à Escola Superior de Agricultura "Luiz de Queiroz", Universidade de São

Paulo, para obtenção do título de Mestre em Ciências, Área de Concentração: Economia Aplicada.
\end{abstract}

P I R A C I C A B A

Estado de São Paulo - Brasil

Outubro - 2002 


\section{Dados Internacionais de Catalogação na Publicação (CIP) DIVISÃO DE BIBLIOTECA E DOCUMENTAÇÃO - ESALQ/USP}

\section{Sonoda, Daniel Yokoyama}

Análise ec onômica de sistema s a ltema tivos de produção de tilá pias em tanques rede para diferentesmercados/ Da niel Yokoyama Sonoda. - Piracicaba, 2002.

$77 \mathrm{p}$.

Dissertação (mestrado) - - Escola Superior de Agricultura Luiz de Queiroz, 2002.

Bibliografia

1. Comérc io 2. Comérc io exterior 3. Indústria pesqueira 4. Mercado intemo 5. Produção (Economia) 6. Tilápia 7. Viabilida de econômica I. Título 
Aos meus pais Issamu e Mary e ao meu irmão

Gustavo que, em todos os momentos me deram

força para prosseguir sempre em frente

DEDICO 


\section{AGRADECIMENTOS}

Ao Professor e amigo Ricardo Shirota pela orientação durante a graduação e o curso de mestrado e ao exemplo de dedicação ao trabalho e preocupação com a formação de seus alunos.

Aos Professores José Eurico Possebon Cyrino, Evaristo Marzabal Neves e Pesquisador João Donato Scorvo Filho por toda a ajuda e apoio necessário para o desenvolvimento e divulgação da pesquisa.

À CAPES pelo auxílio financeiro concedido através de bolsa de estudo durante o curso de mestrado.

Ao corpo docente do Depto. de Economia Administração e Sociologia que propiciaram as condições necessárias para minha formação acadêmica.

Aos amigos Henrique M. Yuri, Vitor A. Ozaki, Roberto A. S. Lima, Rogério E. Freitas, Mauro Osaki e demais companheiros de turma que tornaram estes anos de dedicação ao estudo bastante agradáveis e divertidos.

Ao auxilio na pesquisa e à convivência durante o curso de mestrado agradeço a Luciane Conte, muito mais do que uma amiga, uma companheira em todos os momentos.

Aos funcionários do LES, especialmente à Maielle, Luciane e Ligiana, que sempre estiveram dispostos a nos auxiliar quando necessário. 


\section{SUMÁRIO}

Página

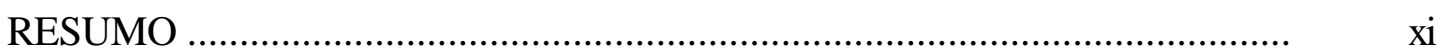

SUMMARY .....................................................................................

1 INTRODUÇÃ

2 SISTEMA AGROINDUSTRIAL (SAG) DO PESCADO NO BRASIL...... 4

2.1 Pesca Extrativa: ....................................................................... 4

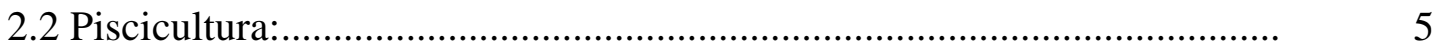

3. PRODUÇÃO DE PESCADOS ..........................................................

3.1 Situação dos Recursos Pesqueiros no Mundo ........................................... 7

3.2 Situação da Pesca no Brasil............................................................... 8

3.3 Evolução Recente da Economia Brasileira e seus Reflexos para o Setor de Pesca

3.4 Piscicultura na Região Sudeste e Sul ..................................................... 13

4 CARACTERIZAÇÃO DO MERCADO DE PESCADOS …........................ 15

4.1 Pesque-pagues no Estado de São Paulo ................................................ 15

4.2 Mercado de Peixes Filetados........................................................... 18

4.3 Mercado Atacadista de Peixes Frescos na CEAGESP ............................. 20

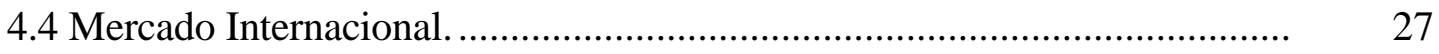

5 MATERIAL E MÉTODOS ................................................................ 30 


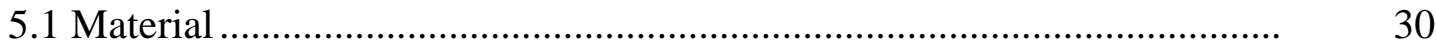

5.1.1 Espécie de Peixe Analisada ..................................................................... 30

5.1.2 Sistema Atual de Produção de Tilápia no Brasil........................................ 31

5.1.3 Caracterização do Sistema de Produção....................................................... 33

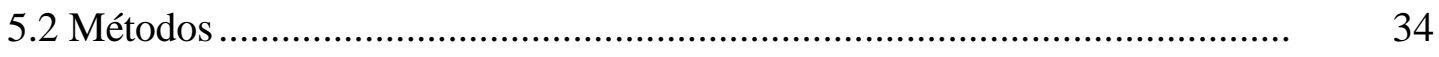

5.2.1 Fundamentos Teóricos ..........................................................................

5.2.1.1 Maximização de Lucro a partir de uma Função de Produção ................. 34

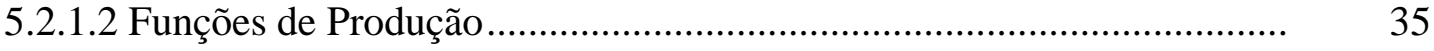

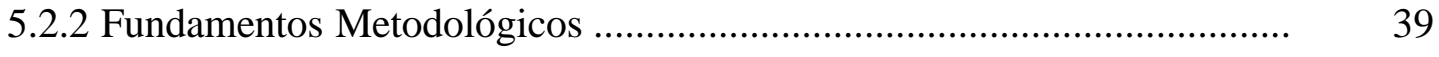

5.2.2.1 Funções de Regressão Utilizadas para Estimar as Curvas de

Produção ................................................................................................. 39

5.2.2.2 Análise da Viabilidade Econômica do Sistema de Produção................. 42

6 RESULTADOS E DISCUSSÃO ……………………………………....... 48

6.1 Determinação das Curvas de Produção ........................................................... 48

6.2 Determinação da Biomassa Econômica por Ciclo de Produção ………........ 55

6.3 Determinação da Rentabilidade do Sistema de Produção ................................ 57

6.4 Análise de Sensibilidade: Simulação de Monte Carlo. .................................. 65

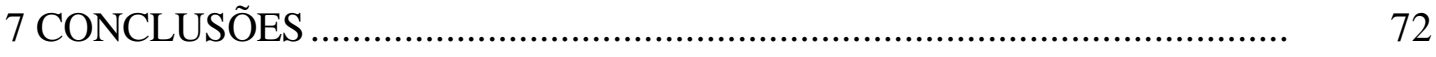

REFERÊNCIAS BIBLIOGRÁFICAS _........................................................... 


\section{LISTA DE FIGURAS}

Página

1 Representação Esquemática do Sistema Agroindustrial (SAG) do

Pescado

6

2 Evolução da produção mundial da pesca e da aqüicultura, 1950 a 1998,

em milhões de toneladas

3 Evolução da produção pesqueira marítima e interior no Brasil, 1978 a 1998, em toneladas.

4 Evolução da produção, da importação, da exportação e do consumo aparente de pescados no Brasil, 1978 a 2000, em toneladas.

5 Evolução da balança comercial brasileira de pescados, 1978 a 2000, em US\$ 1000

6 Valor das Importações de Filés de Merluza, 1996 a 2000, em US\$1000, toneladas, $\mathrm{U} \$ / \mathrm{kg}$ e $\mathrm{R} \$ / \mathrm{kg}$.

7 Quantidade total dos peixes provenientes de água doce e de água salgada comercializados na CEAGESP, 1980 a 1999.

8 Quantidade total de pescados comercializados na CEAGESP nas décadas de 80 e 90

9 Percentual da quantidade de pescados comercializados na CEAGESP nas décadas de 80 e 90 , por estrato de preço.

10 Médias mensais de quantidade e preço dos peixes provenientes de água salgada comercializados na CEAGESP, nas década de 80 e 90.

11 Médias mensais de quantidade e preço dos peixes provenientes de água doce comercializados na CEAGESP, nas década de 80 e 90 
12 Curva hipotética do crescimento da biomassa acumulada em função do consumo de ração.

13 Curva hipotética de crescimento para produção de determinada espécie de peixe em função do tempo

14 Número de ciclos produtivos em função do tempo

15 Representação da função logística.

16 Representação da função Mitscherlich.

17 Curva de peso unitário do peixe $(\mathrm{P})$ em gramas em função do tempo em dias.

18 Curva de biomassa acumulada (BA) em $\mathrm{kg} / \mathrm{m}^{3}$ em função do peso unitário do peixe $(\mathrm{P})$ em gramas

19 Curvas de biomassa acumulada (BA) e quantidade de ração (RA) consumida durante o ciclo de produção em função do tempo de duração do ciclo de produção.

20 Curva de biomassa acumulada (BA) em função da quantidade de ração (RA) consumida durante o ciclo de produção.

21 Comportamento dos diferentes custo de produção acumulados em função do tempo.

22 Comportamento da Receita total (RT), custo operacional total (CT) e custo do alevino/juvenil (CAJ) em função do tempo.

23 Comportamento do Custo do alevino/juvenil (CAJ) em $\mathrm{R} \$ / \mathrm{m}^{3}$ e $\mathrm{R} \$ / \mathrm{kg}$ em função de seu Peso Inicial (g).

24 Número de ciclos de produção por vida útil e tempo de duração de cada ciclo de produção em função do tamanho de entrada do alevino/juvenil.....

25 Comportamento da Margem bruta (MB) em função do Peso Inicial (g) do alevino/juvenil.

26 Valor liquido presente (VLP) em $\mathrm{R} \$ / \mathrm{m}^{3}$ em função do tamanho unitário de entrada do alevino/juvenil. 
27 Taxa interna de retorno (TIR) em \% em função do tamanho unitário de entrada do alevino/juvenil.

28 Distribuição de probabilidade da Taxa Interna de Retorno (TIR) e do Valor Líquido Presente (VLP) comparando duas médias distintas de peso final.

29 Distribuição de probabilidade da Taxa Interna de Retorno (TIR) e do Valor Líquido Presente (VLP) comparando duas médias distintas de Peso Inicial (PI e PI').

30 Distribuição de probabilidade da Taxa Interna de Retorno (TIR) para uma situação hipotética de venda dos peixes para um sistema de exportação de filés para o produtor. 


\section{LISTA DE QUADROS}

\section{Página}

1 Produção Brasileira de Pescados, 1979 a 1999, por Grandes Regiões do País.

2 Preços médios de peixes adultos vivos praticados pelos piscicultores, Estado de São Paulo, para o período de maio a junho de 1995 e o ano de

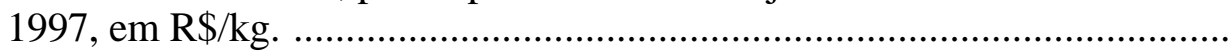

3 Valor percentual da quantidade de pescados comercializados na CEAGESP na década de 90 por espécie e por extrato de preço.

4 Os 10 maiores paises importadores e exportadores de pescados no ano de 1999 em 1000 US\$.

5 Variáveis e distribuições utilizadas para o processo de simulação de Monte Carlo. 


\title{
ANÁLISE ECONÔMICA DE SISTEMAS ALTERNATIVOS DE PRODUÇÃO DE TILÁPIAS EM TANQUES REDE PARA DIFERENTES MERCADOS
}

\author{
Autor: DANIEL YOKOYAMA SONODA \\ Orientador: Prof. RICARDO SHIROTA
}

\section{RESUMO}

Os dados referentes ao setor pesqueiro no Brasil e no mundo mostram que tal recurso natural está bem próximo do limite máximo de exploração. A produção mundial de peixes, no entanto, continua apresentando contínuo crescimento. Este aumento tem sido obtido graças ao crescimento da aqüicultura que vem se mostrando a melhor alternativa para suprir a estagnação da produção pesqueira de captura. No Brasil, o quadro é bastante semelhante, pois nos últimos 20 anos a produção pesqueira nacional reduz sensivelmente. A redução só não é maior, graças ao crescimento gradativo da aqüicultura no País. Atualmente ela é responsável por $19 \%$ da produção nacional de pescados. A Região Sul e o Estado de São Paulo respondem por $71 \%$ dessa produção. Nestes Estados a criação de peixes de água doce, desenvolveu-se em função de uma atividade de lazer relacionada à pesca esportiva denominada pesque pague. Nos últimos anos, porém, a concorrência entre os piscicultores tem trazido dificuldades na comercialização junto a estes estabelecimentos. Dentre as principais dificuldades estão a redução dos preços pagos aos peixes e excessiva demora na colocação do produto no 
mercado. Estes fatos estão fazendo com que os piscicultores busquem alternativas para a colocação de seus peixes. Uma alternativa de mercado para este caso seria o mercados de peixes para alimentação. Porém nesse mercado existe a concorrência com os peixes da pesca extrativa. Ele é predominantemente dominado pela pesca extrativa que além de possuir maior dimensão, possui um número muito maior de espécies e já possui mercado cativo. Assim, este trabalho tem como objetivo geral estudar a viabilidade econômica, do sistema atual de produção da tilápia, visando mercados alternativos à comercialização junto a pesque-pagues e de produtos processados. A partir dos resultados obtidos, são analisadas algumas alternativas tecnológicas no sistema de produção atual, buscando identificar aquela que proporciona maior rentabilidade. Além das adaptações dentro do sistema produtivo atual, o trabalho estuda o no sistema agroindustrial (SAG) da tilápia em um novo conceito de sistema de produção. Os resultados obtidos mostram que a biomassa econômica para a densidade de 236,3 peixes $/ \mathrm{m}^{3}$ foi de $173,66 \mathrm{~kg} / \mathrm{m}^{3}$ o que equivale a uma média de peso de 735 g/peixe. Observou-se também o peso inicial que maximiza a rentabilidade é de $280 \mathrm{~g}$ ao preço de $\mathrm{R} \$ 2,00 / \mathrm{kg}$. Em seguida foram feitas análises de risco para três situações distintas: venda de peixes com peso médio superior ao indicado pela biomassa econômica; pesos de alevinos/juvenis distintos; e, simulação de uma situação de exportação. No primeiro caso verificou-se que, ao se trabalhar com uma biomassa superior a da econômica, os riscos de insucesso do projeto se elevam mais do que quando se trabalha com uma biomassa inferior à econômica. No segundo, ao se iniciar o ciclo de produção com peixes de $280 \mathrm{~g}$, a probabilidade de se elevar a rentabilidade do projeto são superiores aos de se iniciar com peixes de $10 \mathrm{~g}$. Finalmente, o estudo indica que no mercado internacional os riscos de insucesso são bastante semelhantes ao do mercado interno. 


\title{
ECONOMIC ANALYSIS OF ALTERNATIVE SISTEMS OF TILAPIA PRODUCTION IN CAGE FOR DIFFERENTS MARKETS
}

\author{
Author: DANIEL YOKOYAMA SONODA \\ Adviser: Prof. RICARDO SHIROTA
}

\section{SUMMARY}

Recent data about the situation of fisheries in the World and in Brazil indicate some evidences that this resource is near to its maximum level of extraction capacity. However, the World fish production is in continuously increasing. Its growth has been supported by the increasing by aquaculture production, which seems to be the best alternative to the stagnation of fishery production. In Brazil, in the last 20 year, the situation has been very similar. The increase in aquaculture has compensated the reduction of fishery production, which is now responsible for $20 \%$ of the national fish production. The South Region and São Paulo State concentrate $71 \%$ of the national aquatic organisms production. The fresh water aquaculture in these States developed to attend the demand of live fish from the sportive fishing activity denominated "catchand-pay". Recently, the increase in production and the competition between the fish farmers created some commercial troubles. Low prices and lack of demand are some of them. These kinds of obstacles have motivated the fish farmer to look for other market alternatives. The first one is the food market. However, the competition here is very hard from commercial fishing industry. They have large volumes and number of species and 
the consumers are used to them. Thus, this studies objectives is to economically evaluate the production of tilápia for market alternatives like the "catch-and-pay" and the processing industry. Also, analyze it some technological alternatives to the actual system of tilapia production looking for one that gives the highest profit. The proposal of the study is to suggest news concepts of tilapias production systems. The results show that for the system that uses $236,3 \mathrm{fish} / \mathrm{m}^{3}$, the economic biomass was $176,66 \mathrm{~kg} / \mathrm{m}^{3}$, with a medium weight of $735 \mathrm{~g}$ per fish. After that, different sizes of fingerlings were analyzed. It was found that the size that maximized the profit is $280 \mathrm{~g}$ per fish. The risk was estimated for 3 different cases: production until the biomass higher than highest profit; start the production with different sizes of fingerlings; and finally tilapias for exportation. In the first case, if the production is kept until biomass becomes higher than the economic one, the risk of loses is higher than if the farmer sell the fish at biomass lower than the economic. The probability of obtain higher profits is greater if the production starts with larger fingerlings ( $280 \mathrm{~g}$ versus $10 \mathrm{~g}$ ). And, the probabilities of losses in the international market are similar to the domestic "catch-and-pay" market. 


\section{INTRODUÇÃO}

A piscicultura nacional passa por um momento delicado onde a maior preocupação é o mercado. Hoje, praticamente toda a produção da criação de pescado em confinamento é destinada para os pesque-pagues. Neste mercado, a produção da piscicultura não sofre concorrência da pesca extrativa, pois os peixes precisam chegar vivos aos pesque-pagues.

Além das alternativas de mercado, o desenvolvimento da piscicultura depende de adaptações nos diferentes sistemas de produção adotados atualmente. O setor produtivo precisa adaptar-se às restrições impostas pelo mercado, bem como analisar a viabilidade econômica alternativas de produção predominantes. Da mesma forma, é importante estudar o setor dentro de um contexto macroeconômico mais abrangente, visando antever os impactos e as oportunidades no futuro próximo.

Nos últimos 10 anos a produção mundial de pescados vem se mantendo constante, indicando que a exploração deste recurso já chegou (ou está bem próximo) do seu ponto máximo. O caso brasileiro parece ainda pior: a produção nacional apresentou uma sensível redução entre as décadas de 80 e 90. Como conseqüência, desde 1985, o consumo aparente de pescados é maior que a produção nacional. Este déficit está sendo suprido pelas importações. Por outro lado, aparentemente, a elasticidade renda da demanda por pescado é relativamente alta. Também há indícios de que com a elevação do nível de renda da população, a demanda por pescados também se eleve, como ocorreu em 1994 com a implantação do Plano Real.

O peixe é uma importante fonte de alimento. Sendo que em alguns paises, é a principal fonte de proteína da população. 
Nos últimos anos a preocupação com uma alimentação mais saudável e a precaução em se evitar alguns males como os causados pelas gorduras saturadas e pelo excesso de colesterol no sangue tem levado a uma maior procura por carnes branca principalmente a de peixes. Por este fato e acrescido do crescimento da população mundial, espera-se que a demanda por peixes, uma fonte de proteína de alto valor biológico, venha a ter cada vez mais peso no cardápio das pessoas. Por outro lado, ao que tudo indica, a oferta de pescados pela atividade pesqueira está no limite máximo de exploração. Uma forma de suprir esta demanda reprimida é a criação de peixes em confinamento, mais conhecida como piscicultura.

O grande potencial hídrico do território brasileiro, estimado em 5,3 milhões de hectares de água doce represada em grandes reservatórios naturais e artificiais, associado a condições climáticas adequadas e disponibilidade de alimentos completos para piscicultura intensiva, permite uma expansão quase ilimitada da piscicultura em tanquesrede no país.

O grande desafio é saber se a piscicultura é capaz de competir em preço e qualidade, com a pesca extrativa no mercado de alimentos.

A situação atual do câmbio no Brasil favorece produção de substitutos às importações no mercado interno, assim como, a exportação destes produtos. Porém, é necessário ter consciência de que o mercado externo é muito mais exigente que o interno, possuindo uma série de normas e certificações que precisam ser respeitadas para que o produto seja bem aceito.

Este trabalho tem como objetivo geral estudar a viabilidade econômica, incorporando uma análise de risco, do sistema atual de produção da tilápia, visando mercados alternativos à comercialização junto aos pesque-pagues. A partir dos resultados obtidos, analisar algumas alternativas tecnológicas no sistema de produção atual, buscando identificar àquela que proporciona maior rentabilidade. Além, das adaptações dentro do sistema produtivo atual, a proposta do trabalho é de estudar no Sistema Agroindustrial (SAG) da tilápia, um novo conceito de sistema de produção.

Dentre os objetivos específicos propostos estão: determinar as funções de produção de tilápia em tanques-rede; a determinação da biomassa que maximiza a 
rentabilidade do sistema; determinar o tamanho e o preço dos alevinos/juvenis para maximizar a rentabilidade dos sistemas em função do tempo; e analisar as vantagens e desvantagens que a adaptação do sistema para cada situação de mercado oferece. 


\section{SISTEMA AGROINDUSTRIAL (SAG) DO PESCADO NO BRASIL}

O Sistema Agroindustrial do Pescado é constituído pelos segmentos de insumos, produção, transformação, distribuição e consumo, e pode se subdividido em dois subgrupos, segundo a forma de obtenção do pescado: pesca extrativa e aqüicultura (Secretaria da Agricultura e Abastecimento, 1996).

\subsection{Pesca Extrativa}

A pesca extrativa, também chamada de captura, é aquela que retira o pescado do ambiente natural. Suportando esta atividade, existe toda uma infraestrutura ou cadeia colaborando para que o pescado capturado chegue até o consumidor final. Esta cadeia pode ser subdividida nos seguintes seguimentos:

- O primeiro segmento supre os fatores de produção e insumos necessários ao desenvolvimento da atividade como: embarcações, motores, equipamentos, apetrechos de pesca, eletricidade, mão de obra, combustível, gelo, máquinas, transporte e outros.

- O segmento produtivo é representado pela pesca propriamente dita. Ela está incluída entre as atividades econômicas do setor primário da economia. A atividade de produção do SAG do pescado apresenta características especiais em relação à produção dos outros tipos de carnes. Na maioria dos casos, a carne precisa ser produzida pela atividade de criação. Ao contrário, no caso do peixe, a atividade de produção é a própria pesca que extrai o organismo aquático do seu ambiente natural. 
- O segmento de transformação é composto pelas indústrias que processam o pescado, introduzindo alterações na forma de apresentação, na estrutura química e nas características físicas. Essas modificações visam atender às necessidades e desejos dos consumidores, proporcionando melhores condições de conservação e de qualidade ao produto.

- O segmento de distribuição abrange os entrepostos, intermediários, feiras livres, supermercados, peixarias e ambulantes. Este segmento é o que entra em contato com o consumidor final do peixe. Em alguns casos, os próprios produtores vendem o pescado diretamente para o consumidor final.

- O SAG do pescado encerra-se com o consumidor final (Figura 1).

\subsection{Piscicultura}

A piscicultura é a atividade de criação de peixes em confinamento. Atualmente, a piscicultura tem uma participação muito insipiente no mercado de peixes destinados à alimentação humana. Seu principal mercado é o de pesque-pagues.

A cadeia da piscicultura possui os seguintes segmentos:

- O primeiro segmento supre os fatores de produção e insumos necessários ao desenvolvimento da atividade, tais como mão de obra, máquinas e equipamentos, transporte, eletricidade, ração, tanques e outros.

- O segundo segmento é o setor produtivo propriamente dito. Ele é representado pela aqüicultura que é a criação de organismos aquáticos em ambientes naturais e artificiais, como lagoas, rios, açudes, represas, viveiros e tanques construídos para este fim. Deve-se destacar que esta atividade depende ainda de um fator natural renovável que é a água.

- O segmento seguinte é a distribuição. No caso da venda de peixes vivos, ele dividido em duas partes. Em primeiro lugar, o segmento é ocupado pelos intermediários ou transportadores de peixes que ligam as pisciculturas com os pesque-pagues. $\mathrm{E}$, em seguida, estes últimos encarregam-se de colocar o 
consumidor final em contato com o peixe. No segmento da distribuição existe ainda uma outra alternativa de escoamento da produção através dos canais de comercialização utilizados pela pesca extrativa. Neste caso, os segmentos de transformação, distribuição e consumo são semelhantes aos utilizados pela pesca extrativa e descritos acima.

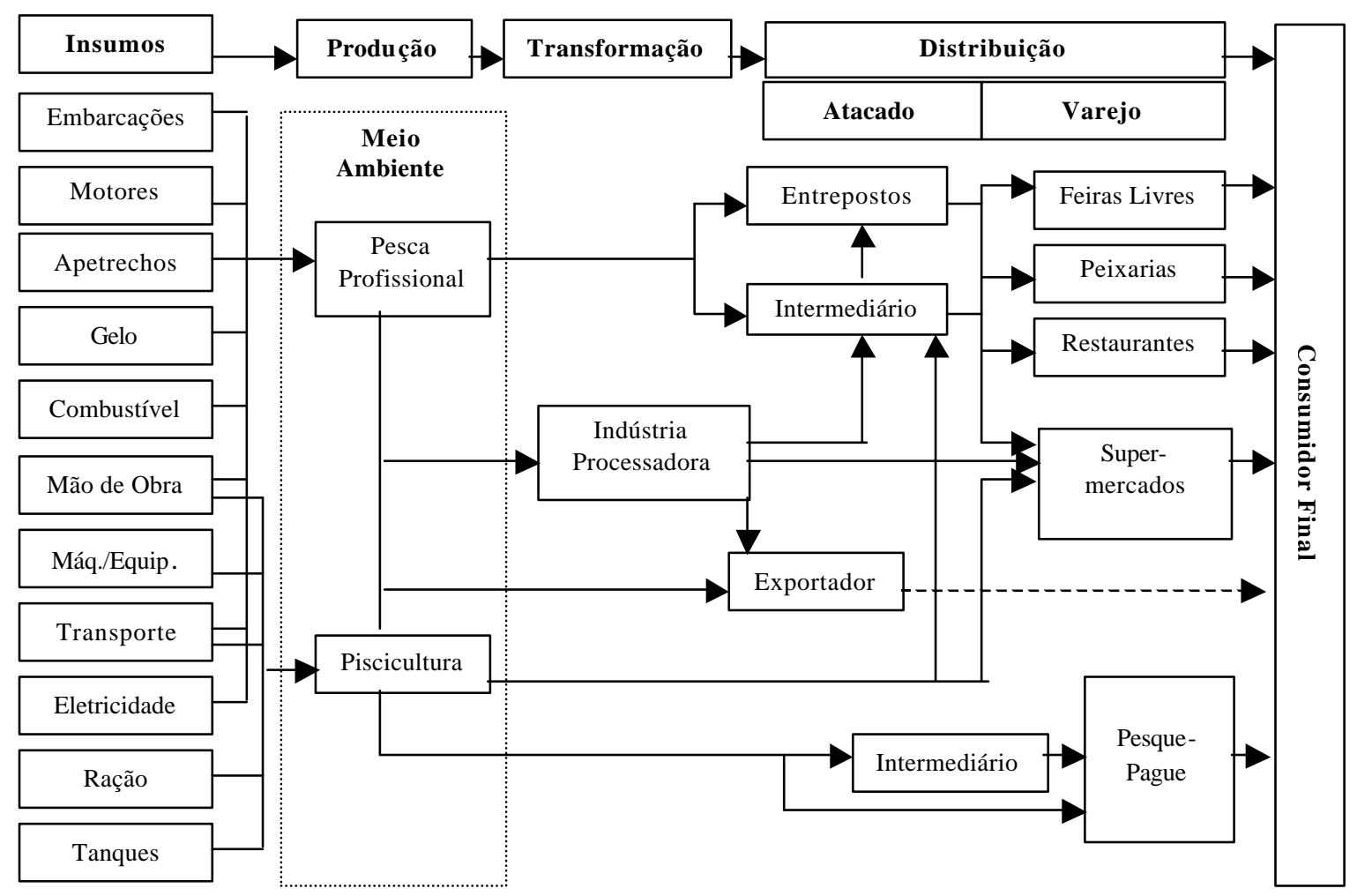

Figura 1 - Representação Esquemática do Sistema Agroindustrial (SAG) do Pescado.

Fonte: Adaptado de Secretaria da Agricultura e Abastecimento (1996) 


\section{PRODUÇÃO DE PESCADOS}

\subsection{Situação dos Recursos Pesqueiros no Mundo}

Por duas décadas a partir de 1950, a produção mundial da pesca marítima e em águas interiores cresceu a uma taxa de $6 \%$ ao ano (FAO, 2000). Nesse período, a pesca mundial triplicou de produção, passando de 18 milhões de toneladas em 1950 para 56 milhões de toneladas em 1969. Nas duas décadas seguintes, de 70 e 80, a taxa média de crescimento da produção caiu para $2 \%$ ao ano, chegando a quase zero na década de 90 ( Figura 2).

Essa tendência de redução do crescimento da captura de peixe está ocorrendo na maioria das áreas de pesca do mundo. Aparentemente, esse recurso atingiu o seu potencial máximo de produção, indicando que a maior parte dos estoques já estão sendo explorados em sua plenitude. Em contrapartida, o crescimento da produção da aquiicultura tem mostrado uma tendência oposta. Começando com valores insignificantes no início da década de 50, a produção da aqüicultura marítima e em águas interiores apresentou crescimento anual médio de cerca de 5\% a.a. até 1969. Essa taxa de crescimento aumentou para $8 \%$ a.a. nas décadas de 70 e 80, e desde 1990 vem crescendo a uma taxa superior a $10 \%$ a.a.

No mundo, atualmente, a China é o maior produtor mundial de pescados, respondendo por cerca de $32 \%$ da quantidade total capturada anualmente. Em ordem de importância, aparecem Japão, Índia, Estados Unidos, Rússia e Indonésia. 


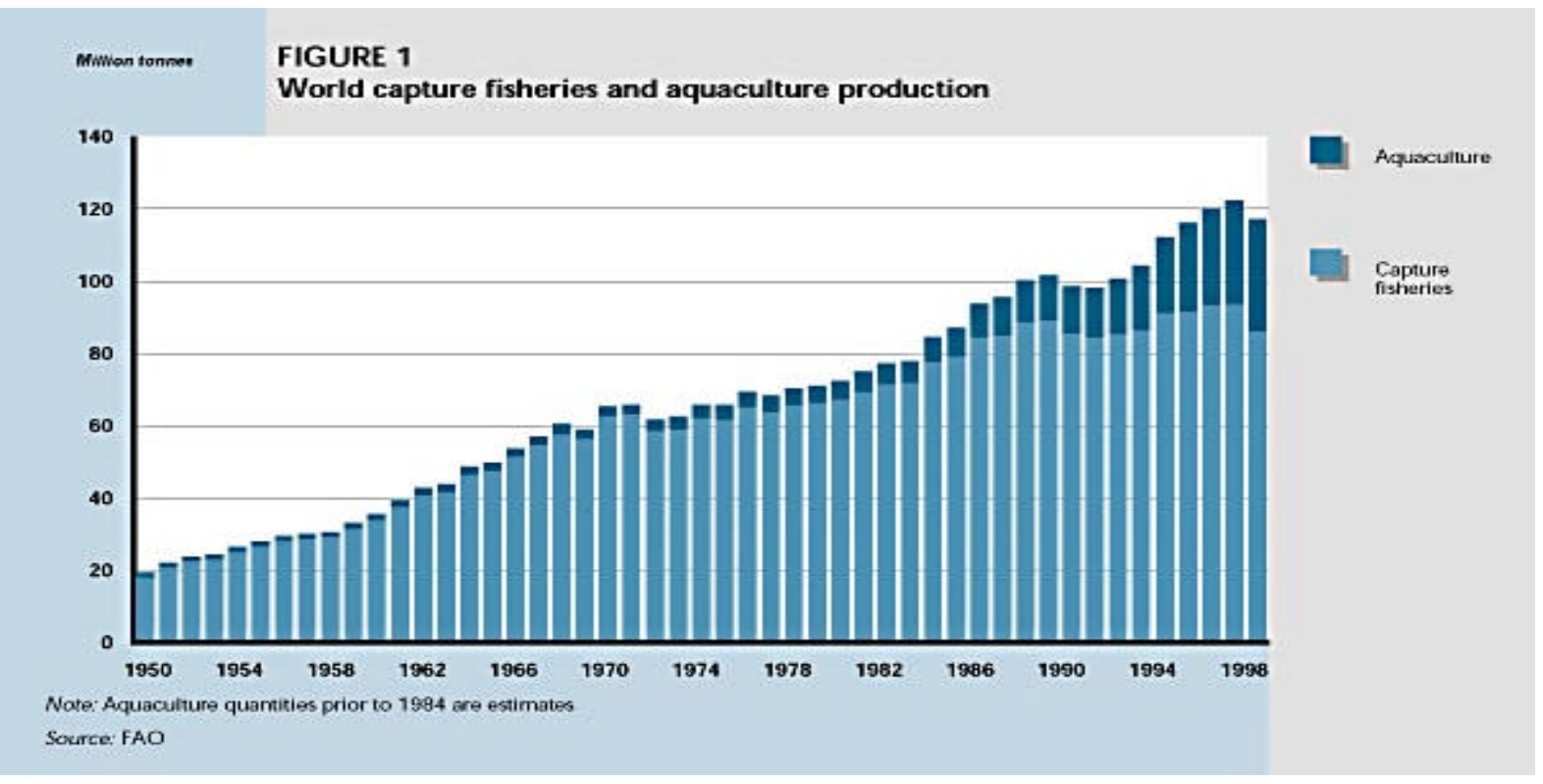

Figura 2 - Evolução da produção mundial da pesca e da aqüicultura, 1950 a 1998, em milhões de toneladas.

Fonte: Food and Agricultural Organization (2000)

\subsection{Situação da Pesca no Brasil}

Entre 1967 e 1986, o governo brasileiro criou um programa de incentivos para o setor que movimentou recursos da ordem de $\mathrm{R} \$ 1,9$ bilhões (deflacionados para janeiro de 2001). Isto proporcionou um aumento na produção pesqueira nacional que passou de 429 mil t/ano em 1967 para 941 mil t/ano em 1986 (Abdallah, 1998). Após este período observa-se uma queda acentuada na produção pesqueira, principalmente, da pesca marítima (Figura 3). 


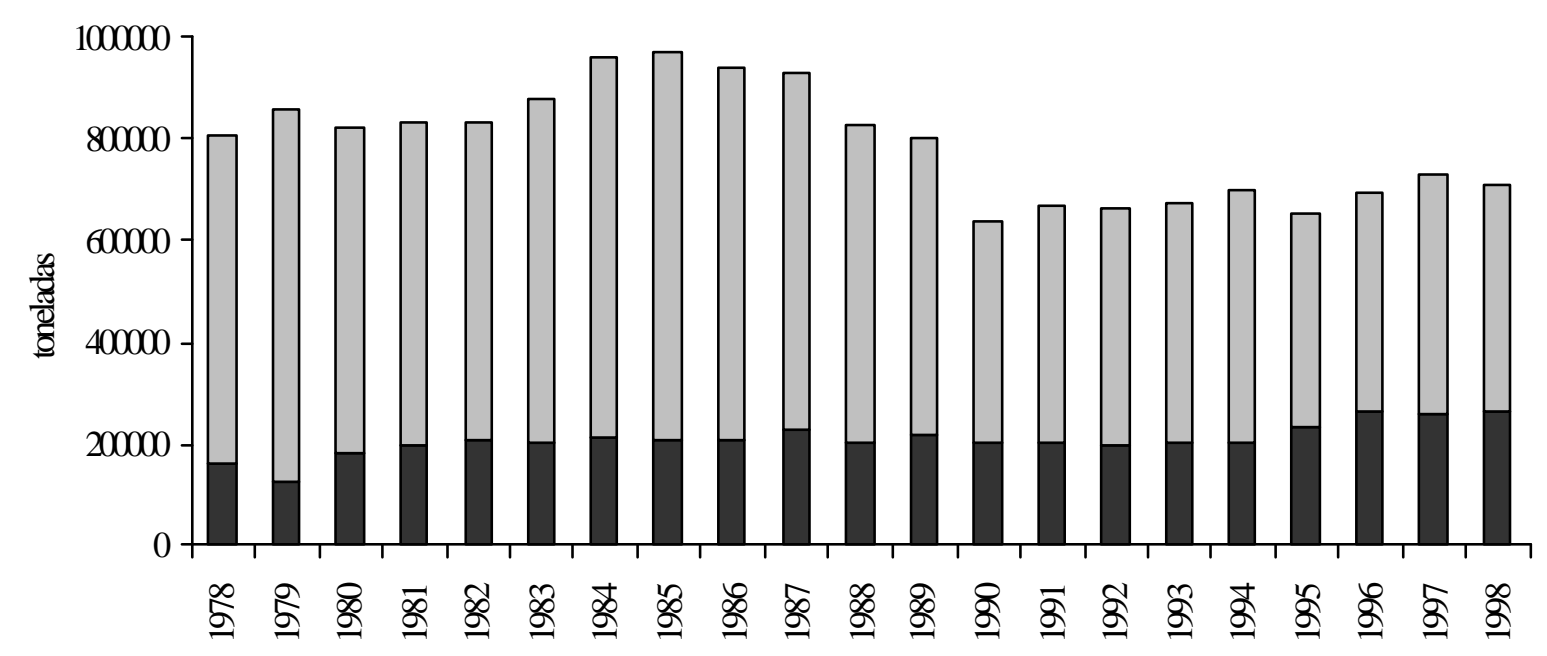

$\square$ interior $\square$ mantíma

Figura 3 - Evolução da produção pesqueira marítima e interior no Brasil, 1978 a 1998, em toneladas.

Fonte: Adaptado de Abdallah (1998)

Nota: Dados de produção pesqueira de 1998 retirados de IBAMA (2000)

A maior parte destes incentivos (98,79\%), foi destinada às regiões Sul e Sudeste $(77,52 \%)$ e Nordeste $(15,27 \%)$. E, grande parte dele foi investido no setor industrial e de captura.

Em termos de produção as regiões Sul e Sudeste eram as que respondem pela maior quantidade de pescados. Porém, a maior parte dela era de baixo valor unitário e atendem, principalmente, o mercado interno. A região Nordeste, ao contrário, produz pescados finos, de alto valor unitário médio. A sua produção é direcionada, em grande parte, para a exportação.

No setor de processamento, a produção de pescados congelados está concentrada nos estados do Rio Grande do Sul e Santa Catarina. Os estados do Rio de Janeiro e São Paulo abrigam a maior parte da produção de conservas de sardinha, atum, camarão, bonito, entre outras espécies. O Estado do Ceará destaca-se pela produção de lagostas. Os outros Estados da Região Nordeste e Norte destacam-se a pesca do camarão, piramutaba, pargo etc. 
Deve-se destacar, ainda, a ocorrência de uma significativa mudança no panorama regional da pesca nos últimos 20 anos (Abdallah, 1998). Nesse período, ocorre uma substancial redistribuição da pesca entre as diferentes Regiões do País. Em 1979, as Regiões Sul e Sudeste respondiam pela maior parte da produção nacional. Porém, em 1999, as Regiões Norte e Nordeste passam a ser as regiões de produção mais significativas (Quadro 1).

Uma outra mudança que merece destaque é o aumento da produção oriunda da aqüicultura. Estima-se que, em 1979, ela tenha produzido 343 t. Vinte anos depois, em 1999, a sua produção cresceu para 140.657 t, representando cerca de $19 \%$ da produção nacional de pescados. Dessa produção, cerca de $81 \%$ provém da água doce. E, na aqüicultura de água doce, os principais estados produtores são Rio Grande do Sul (27\%), Paraná (18\%), Santa Catarina (14\%) e São Paulo (12\%).

\begin{tabular}{|cccc|}
\hline Região & Produção 1979 $(\mathrm{t})$ & Produção 1999 $(\mathrm{t})$ & Variação $(\%)$ \\
\hline Norte & 90.869 & 206.822 & 127 \\
Nordeste & 164.095 & 200.854 & 22 \\
Sudeste & 280.966 & 123.671 & -56 \\
Sul & 317.501 & 188.266 & -41 \\
Centro Oeste & 4.752 & 24.986 & 426 \\
\hline Total & 858.183 & 744.599 & -13 \\
\hline
\end{tabular}

Quadro 1 - Produção Brasileira de Pescados, 1979 a 1999, por Grandes Regiões do País. Fonte: IBAMA (2000)

\subsection{Evolução Recente da Economia Brasileira e seus Reflexos para o Setor de Pesca}

Nas últimas três décadas, o padrão de consumo familiar de bens e serviços no Brasil apresentou clara segmentação como consequiência do perfil de distribuição da renda nacional (BNDES, 1996). A população de renda mais elevada sustentou a expansão da indústria de bens duráveis, enquanto as faixas de menor poder aquisitivo foram responsáveis pela maior parte das despesas em bens não duráveis. 
O período entre 1986 e 1993 foi marcado por recessão econômica e alta taxa de inflação, movimentos stop-and-go, incertezas políticas e sucessivas tentativas fracassadas de estabilização. Além disso, este período foi caracterizado pelo crescimento do desemprego, diminuição do salário médio, distorções de preços relativos e erosão do poder de compra dos consumidores. As conseqüências foram negativas sobre a demanda e houve queda expressiva nas vendas do varejo brasileiro.

Nos anos de 1990 e 1994, ocorreram o inicio da abertura da economia e a estabilização econômica com a implantação do Real, respectivamente. A estabilidade da moeda e o aumento do poder aquisitivo da população, especialmente a de mais baixa renda, resultou em crescimento do consumo, principalmente, de alimentos.

Estes fatos estão relacionados com a recente evolução do setor de pesca no Brasil. Por um lado, a queda na demanda causada pelas crises econômicas no período entre 1986 e 1993 afetou a demanda por pescados. Por outro lado, a oferta foi negativamente afetada pelo final dos programas de incentivos fiscais voltados para o setor. Para agravar o problema, existem evidências de que a crise da pesca foi também causada pela redução dos cardumes, principalmente, de sardinha e camarão no litoral de São Paulo e estados vizinhos. Somados, esses fatores contribuíram para a redução do consumo aparente no período (Figura 4). O começo do processo de abertura da economia brasileira, em 1990, não trouxe consequiências drásticas à balança comercial brasileira de pescados. No entanto, com a implantação do Real observou-se um nítido aumento no déficit da balança comercial de pescados. Isso foi causado pela combinação de três efeitos. Em primeiro lugar, conforme já mencionado, o Plano Real resultou em um aumento significativo da demanda por alimentos, inclusive a de pescado. Porém, em segundo lugar, como a produção nacional de peixes encontra-se estagnada desde 1990, a diferença entre a demanda e a oferta doméstica foi suprida pela importação. E, em terceiro lugar, a valorização cambial, observada nos anos iniciais do Plano Real, tornou a importação ainda mais interessante. (Figura 5).

Nesse período, a maior parte das importações de pescado eram de peixes de baixo valor provenientes, principalmente, da Argentina (marítima - pescada e merluza e 
fluvial - curimbatá e piapara) e do Uruguai (fluvial - curimbatá e piapara). Mas, o País importa, também, peixes de alto valor como o salmão proveniente do Chile.

Num período mais recentemente, a partir de 1999, com a desvalorização do Real, observa-se uma nítida redução no déficit da balança comercial de pescados.

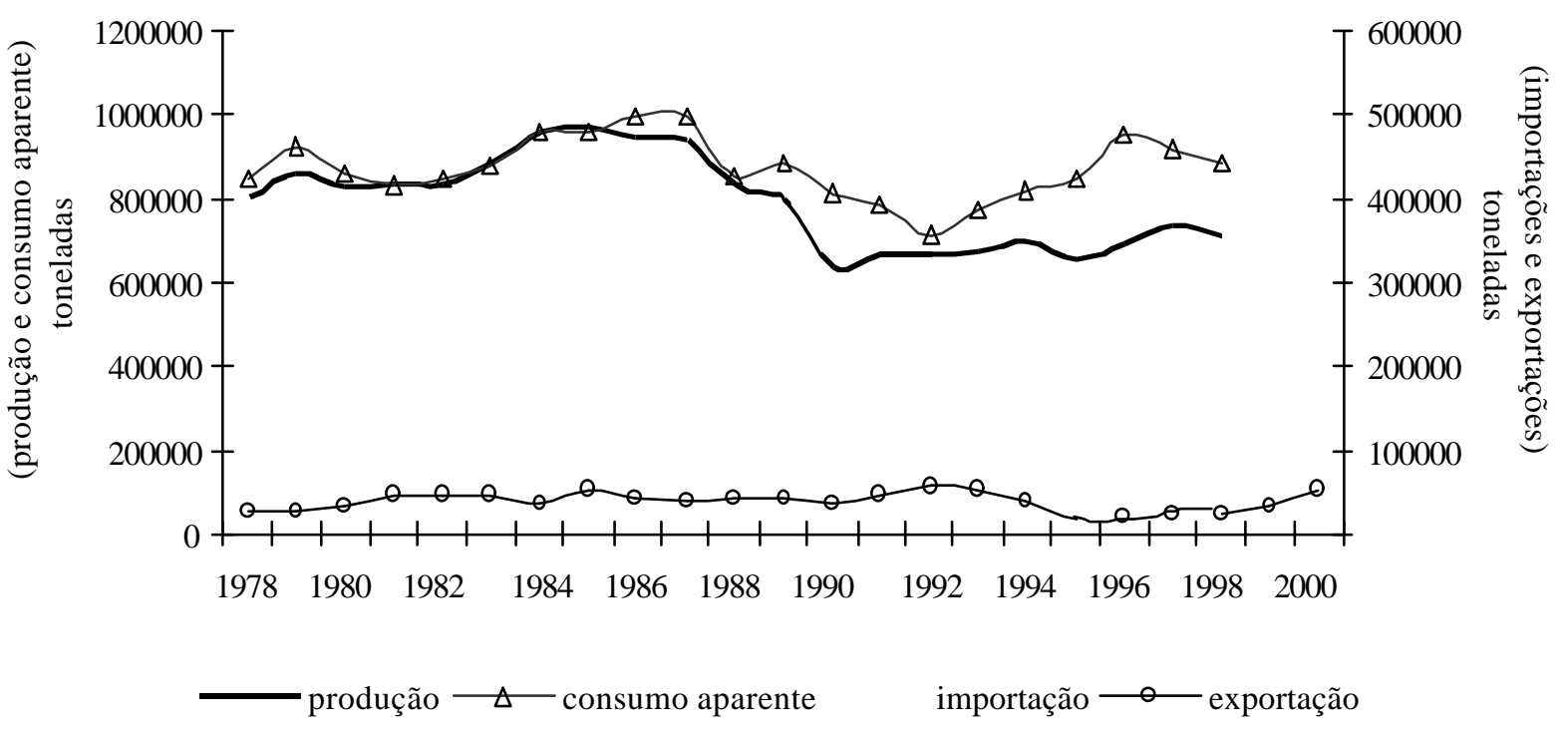

Figura 4 - Evolução da produção, da importação, da exportação e do consumo aparente de pescados no Brasil, 1978 a 2000, em toneladas.

Fonte: Adaptado de Abdallah (1998) - de 1978 a 1998

Nota: Dados de importação e exportação de 1999 e 2000 retirados da Secretaria do Comercio Exterior MDIC (2001) 


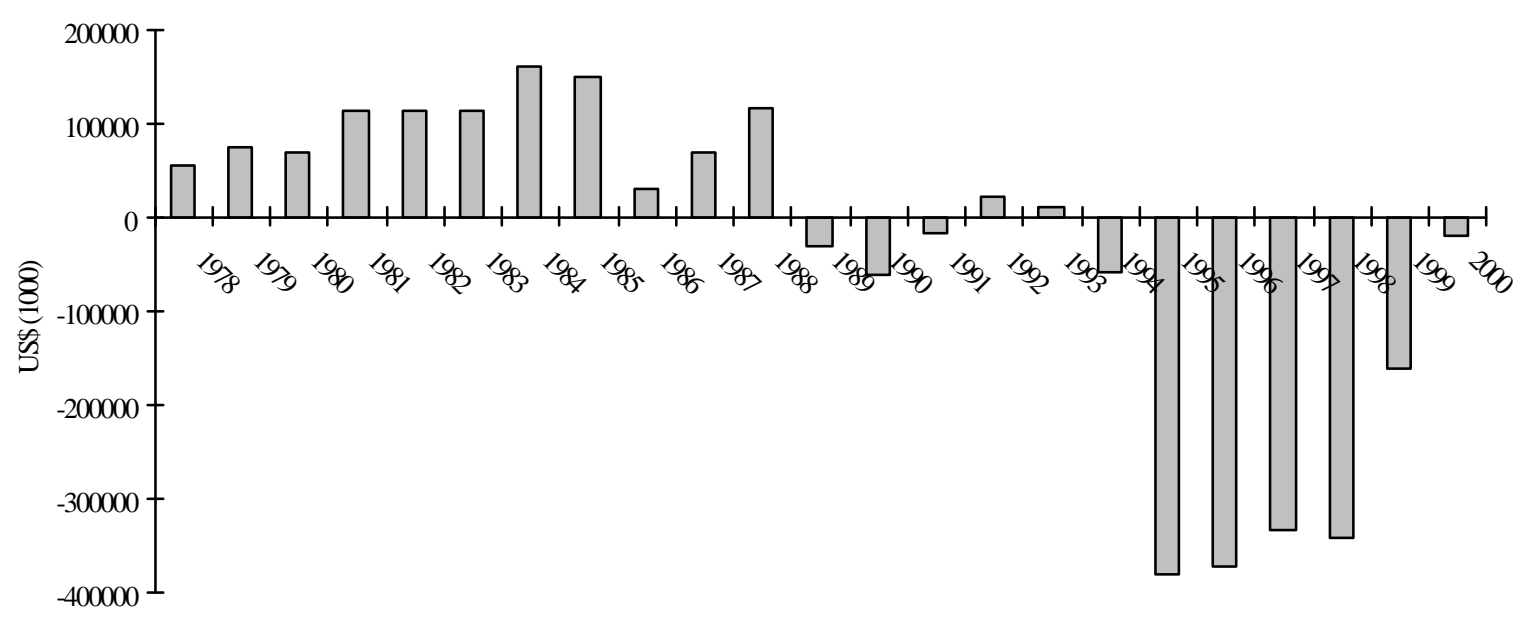

Dbalança comercial de pescados

Figura 5 - Evolução da balança comercial brasileira de pescados, 1978 a 2000, em US\$ 1000.

Fonte: Adaptado de Abdallah (1998) - de 1978 a 1998

Nota: Dados de importação e exportação de 1999 e 2000 retirados da Secretaria do Comércio Exterior MDIC (2001)

\subsection{Piscicultura na Região Sudeste e Sul}

Estima-se que, em 1995, existiam cerca de 950 piscicultores gerando uma produção de cerca de 8.000 toneladas no Estado de São Paulo (Scorvo et al., 1998). As piscigranjas deste Estado apresentavam tamanho médio de 1,8 ha de espelho d'água e em grande parte adotavam um sistema semi-intensivo de criação. Com essa produção, o Estado de São Paulo era reconhecido como o segundo maior produtor nacional, atrás somente do Estado do Paraná, cuja produção estimada era de 10.000 toneladas.

Observações mais recentes, em várias unidades produtoras no Estado de São Paulo, indicam que a produção para 1997 foi de 15.000 toneladas. Este crescimento pode ser observado pela expansão dos demais componentes da cadeia produtiva da 
piscicultura, como as fábricas para rações de peixe que, entre 1992 e 1997, passaram de 5 para 37 unidades instaladas no País (Coelho, 1997).

$\mathrm{O}$ rápido crescimento da piscicultura deveu-se, principalmente, ao aumento do número de pesqueiros particulares que, funcionando no sistema "pesque-pague", passaram a constituir uma nova atividade econômica. Aliada à indústria do turismo rural, os pesque-pagues passaram a oferecer aos praticantes da pesca esportiva toda uma infraestrutura de lazer ${ }^{1}$ (Zanata, 1996).

Os peixes podem ser produzidos no próprio Estado de São Paulo, ou em outros Estados como: Paraná, Santa Catarina, Rio Grande do Sul, Minas Gerais e Mato Grosso do Sul, dependendo de sua espécie e do seu tamanho. No Estado de São Paulo, durante a safra de 94/95, os custos de produção de tilápia ficaram entre $\mathrm{R} \$ 1,16 / \mathrm{kg}$ e $\mathrm{R} \$ 1,43 / \mathrm{kg}$ e na safra 96/97 ficaram entre R\$ 1,32/kg e R\$ 2,21/kg (Scorvo e Ayrosa, 1996 e Scorvo et al, 1998).

\footnotetext{
${ }^{1}$ Entre outras opções, podem ser destacadas as seguintes: estacionamento, play-ground, bar, restaurante, eventualmente churrasqueiras, apetrechos de pesca etc.
} 


\section{CARACTERIZAÇÃO DO MERCADO DE PESCADOS}

Nesta caracterização foram considerados quatro mercados distintos. O primeiro trata do mercado tradicional dos peixes produzidos na piscicultura que foi o mercado de peixes vivos para os pesque-pagues. O segundo foi o de filés de peixe comercializados no país. Este mercado já existe para os peixes de piscicultura, porém ainda é insipiente e vem enfrentando dificuldades, como a concorrência da pesca extrativa. O terceiro é o mercado de peixes frescos vendido no atacado. Para caracterizar este mercado foram analisados os dados fornecidos pelo Departamento de Economia da Companhia de Entrepostos e Armazéns Gerais do Estado de São Paulo (CEAGESP). Nesta análise é interessante notar os diferentes peços obtidos para as diferentes espécies de peixe. E, o quarto mercado analisado foi o mercado de filés de peixes para exportação. No mercado internacional, principalmente no mercado norte americano e europeu, onde já existe o hábito de consumo de filés de tilápia. Porém, se trata de um mercado mais exigente em qualidade e que remunera melhor o produto.

\subsection{Pesque-pagues no Estado de São Paulo}

O pesque pague é uma atividade de lazer, cujo principal atrativo é a pesca. Nos últimos 10 ou 15 anos, esta atividade mostrou-se muito dinâmica, expandindo-se de maneira significativa, principalmente, ao redor de centros urbanos mais populosos. Segundo o IBAMA, órgão que até recentemente regulamentava esta atividade, a região metropolitana de São Paulo detém 30\% do total destes estabelecimentos, ou seja, 960 pesqueiros (Araújo, 1998). 
A expansão desta atividade criou uma demanda pelos produtos da criação de peixes na medida em que, nos pesque-pagues, os peixes precisam chegar vivos. Assim, na medida em que boa parte dos pesqueiros não possui unidades de criação vinculada, os peixes comercializados por eles são oriundos exclusivamente da piscicultura. Estima-se que esses estabelecimentos consumam cerca de 17.000 toneladas anuais de peixe (Ruivo e Pollonio, 1998).

Em 1998, os proprietários de "pesque-pague" pagavam entre $\mathrm{R} \$ 1,5 / \mathrm{kg}-\mathrm{R} \$$ 2,5/kg pelo peixe vivo, enquanto que os freqüentadores pagavam, em média, $\mathrm{R} \$ 4,40 / \mathrm{kg}$. Geralmente é cobrada também uma entrada que custa em média de $\mathrm{R} \$ 5,00 \sim 25,00$ por pessoa (Zanatta, 1996). Obviamente, os diferenciais de preços são altos devido aos gastos com manutenção do cardume e os problemas específicos da atividade, tais como: assiduidade da clientela, fatores climáticos (tempo frio, nublado, chuvoso, etc.), infraestrutura (inclusive de lazer) etc.

É interessante observar também que existe maior valorização das espécies que são considerados mais esportivos e, principalmente, pelo chamados peixes "troféu". Essas espécies atingem este status por causa da fama entre os pescadores ou por seu tamanho, ou por ambas as qualidades. Entre outros, são exemplos de peixes "troféu": pacus e tambaquis de grande porte, dourado, pintado, matrinxã etc. Estes peixes funcionam como atrativos de pescadores e são adquiridos pelos pesqueiros por preços muito altos em função de sua elevada demanda por parte dos pescadores e a sua oferta limitada causada pelas dificuldades na sua criação ${ }^{2}$.

2 No caso dessas espécies, os alevinos são de difícil aquisição e os seus preços são ainda altos. Além disso, a tecnologia de criação dessas espécies não está completamente dominada e ainda existem vários problemas que precisam ser estudados. 


\begin{tabular}{|llcc|}
\hline Espécie & 1995 & 1997 & $(\%)$ \\
\hline Piauçu & 2,67 & 1,80 & $-3,79$ \\
Pacu & 3,20 & 2,92 & $-8,75$ \\
Tambaqui & 3,33 & 2,84 & $-14,71$ \\
Tambacu & 3,17 & 2,98 & $-5,99$ \\
Tilápia do nilo & 2,50 & 2,59 & 3,60 \\
Carpa comum & 2,90 & 2,66 & $-8,28$ \\
Carpa cab. Gr. & 2,75 & 2,71 & $-1,45$ \\
Carpa prateada & 2,75 & 2,77 & 0,73 \\
Carpa capim & 2,83 & 2,78 & $-1,77$ \\
Bagre africano & 2,67 & 1,80 & $-32,58$ \\
Curimbatá & 2,67 & 2,59 & $-3,00$ \\
\hline Média & 2,90 & 2,70 & $-6,93$ \\
\hline
\end{tabular}

Quadro 2 - Preços médios de peixes adultos vivos praticados pelos piscicultores, Estado de São Paulo, para o período de maio a junho de 1995 e o ano de 1997, em $\mathrm{R} \$ / \mathrm{kg}$.

Fonte: Scorvo et al. (1999)

Em 2001, em um levantamento feito a campo na região de Marília-SP o preço da tilapia do nilo foi estimado entre $\mathrm{R} \$ / \mathrm{kg} 1,80$ a 2,20. Trata-se de um mercado sazonal onde o período do ano mais favorável para a comercialização dos peixes vai de outubro à março. Nesta época, os pesque pagues possuem maior demanda de clientes por ser um período quente, mais favorável à pesca e mais agradável para as atividades ao ar-livre.

Para o piscicultor, em geral, as despescas são parceladas, pois dependem da capacidade e necessidade de peixes dos pesque pagues que atendem e/ou da capacidade de carga do caminhão de transporte, que varia de 1600 a $2500 \mathrm{~kg} / \mathrm{viagem}^{3}$. Além do serviço de transporte propriamente dito, o transportador de peixes desempenha um importante papel neste sistema como intermediário entre os criadores de peixe e os pesque-pagues. Grande parte das negociações entre esses dois agentes da cadeia produtiva ocorre por seu intermédio.

3 Essa situação é ruim para o produtor na medida em que aumenta a quantidade de trabalho e os seus custos. 


\subsection{Mercado de Peixes Filetados}

Neste mercado são comercializados produtos semi-acabado, onde o peixe encontra-se limpo, em filé e congelado. Uma parcela significativa deste mercado é ocupada pelo filé de merluza. Trata-se de um peixe de água salgada cuja demanda, até 1998 foi abastecida, em grande parte, pela importação (Figura 6). Em 1996, por exemplo, o Brasil importou 84.034 toneladas do produto. Somente na Região Metropolitana de São Paulo teria consumido 34.453 toneladas de filés, vendidos no varejo na faixa de preço entre $\mathrm{R} \$ 4,00$ a 6,00/kg. Além do produto importado, no mesmo ano, estima-se que as indústrias paulistas e da Região Sul do País (principalmente Santa Catarina) abasteceram o mercado da Grande São Paulo com cerca de 3.600 toneladas de pescado congelado (Ruivo e Pollonio, 1998).

A grande participação da importação no abastecimento do mercado de filés de merluza pode ser um forte indicativo de que existe um déficit de filés de peixe no mercado interno. Por outro lado, é importante observar que este produto tem um preço relativamente baixo no mercado de peixes ${ }^{4}$. Assim, para ser competitivo, o filé de tilápia deverá ter um custo de produção compatível com os principais produtos concorrentes.

No caso da oferta doméstica, os Estados do Paraná e Alagoas foram os pioneiros no incremento da industrialização de tilápias. Em função da regularidade e volume de produção das suas piscigranjas, no Paraná, a atividade tem uma linha de produção programada (Maranhão, 1998). Os outros Estados estão gradativamente implantando projetos similares. Entretanto, a falta de estudos prévios de viabilidade ${ }^{5}$ desses

\footnotetext{
4 Na verdade, esse tipo de análise deve ser feito com cuidado. O preço do produto importado no mercado doméstico, depende do seu preço no mercado internacional, da taxa de câmbio e dos custos de intermediação. No caso do filé de merluza, a combinação desses fatores fez com que o preço doméstico do produto tivesse um aumento considerável entre 1996 e 2000. Conseqüentemente, as importações (tanto em volume quanto em valor) diminuiram consideravelmente nesse período (Figura 5.), indicando uma grande sensibilidade da demanda em relação às variações de preços. Nessa Figura é particularmente claro o efeito da desvalorização cambial ocorrida no ano de 1999, tanto sobre os preços em Reais quanto nas importações em 1999 e 2000.

5 Os seguintes estudos são, particularmente importantes: análise de preços e de mercado, organização e desenvolvimento do mercado, custo de produção e de comercialização e planejamento da comercialização.
} 
empreendimentos poderá colocar em risco o desenvolvimento deste sistema agroindustrial (Marques \& Aguiar, 1993).

No Estado do Paraná, as processadoras e beneficiadoras de pescado pagam entre $\mathrm{R} \$ \quad 0,95 / \mathrm{kg}$ a $\mathrm{R} \$ 1,20 / \mathrm{kg}$ de peixe criado em confinado (Oba et al., 2000). Aparentemente, a partir deste preço pago ao produtor é possível obter um produto final com um preço competitivo na faixa entre $R \$ 4,13 / \mathrm{kg}$ a $\mathrm{R} \$ 5,50 / \mathrm{kg}$ de filé na processadora (Maranhão, 1998).

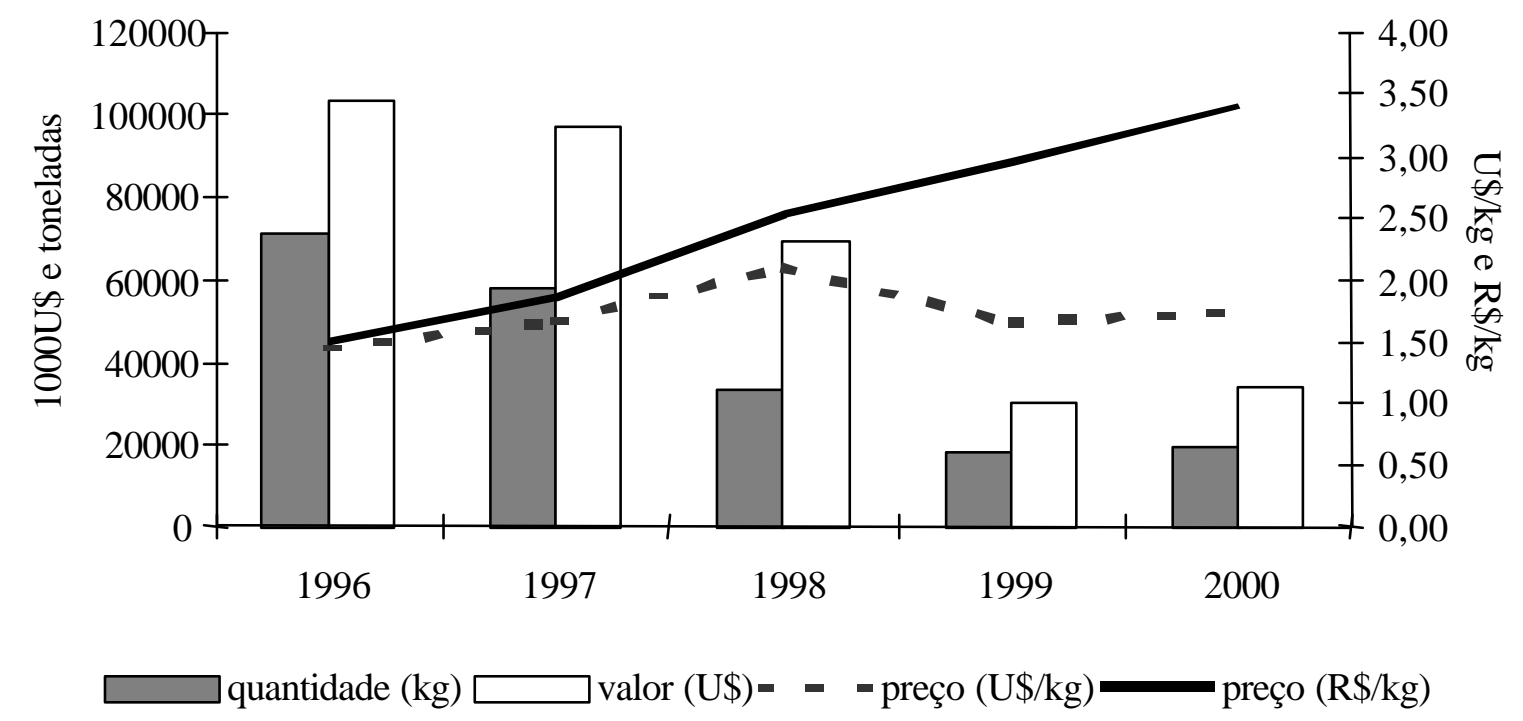

Figura 6 - Valor das Importações de Filés de Merluza, 1996 a 2000, em US\$1000 toneladas, U\$/kg e R $\$ / \mathrm{kg}$.

Fonte: Secretaria do Comércio Exterior - MICT (2001)

Observa-se que, de 1996 a 1999, houve uma redução gradual nas importações de filés de merluza. A partir de 1999, com a maxi-desvalorização do Real perante o dólar, há uma redução no preço do produto em $U \$ / \mathrm{kg}$, esta redução não consegue conter a elevação do preço do produto no mercado interno, acarretando uma diminuição nas quantidades importadas de filés de merluza. Aparentemente, a partir de 2000 as importações se estabilizaram em torno de 20.000 t/ano. A Figura 6 mostra ainda que este 
produto tem se mostrado sensível ao aumento de preço, havendo diminuição das importações com o aumento do preço.

\subsection{Mercado Atacadista de Peixes Frescos na CEAGESP}

Um terceiro canal, potencialmente interessante, para o escoamento da produção da piscicultura trata-se da comercialização por atacado feita, principalmente pela Companhia de Entrepostos e Armazéns Gerais de São Paulo (CEAGESP). Lá se encontra o maior entreposto de pescados da América Latina e que serve não só a capital como, também, as diversas cidades do interior do Estado e outros Estados da Federação.

A CEAGESP, que pertencia Governo do Estado de São Paulo, passou a ser propriedade do Governo federal em $1^{\circ}$ de janeiro de 1998. O Entreposto de pescado funciona de terça-feira à sábado, com um maior movimento de vendas no horário entre 02:30 h e as 05:00 h, e é composto de 3 pátios: (1) o primeiro com 76 módulos onde são comercializadas mais de 150 espécies de pescado fresco; (2) o segundo que possui 24 módulos, onde são comercializados produtos congelados; (3) uma terceira plataforma onde são comercializadas apenas duas espécies de peixes: a sardinha e a cavalinha. Até a década de 80 este pátio comercializava somente sardinha, que nos últimos anos vem sofrendo uma queda na produção causada pela sobrepesca (Sonoda et al., 2000a).

A CEAGESP movimenta anualmente cerca de 7,5\% do consumo aparente de pescados do Brasil. Do volume comercializado no entreposto, apenas 6,5\% do total de peixes é proveniente de água doce, sendo que o restante provém de água salgada (Figura 7). 


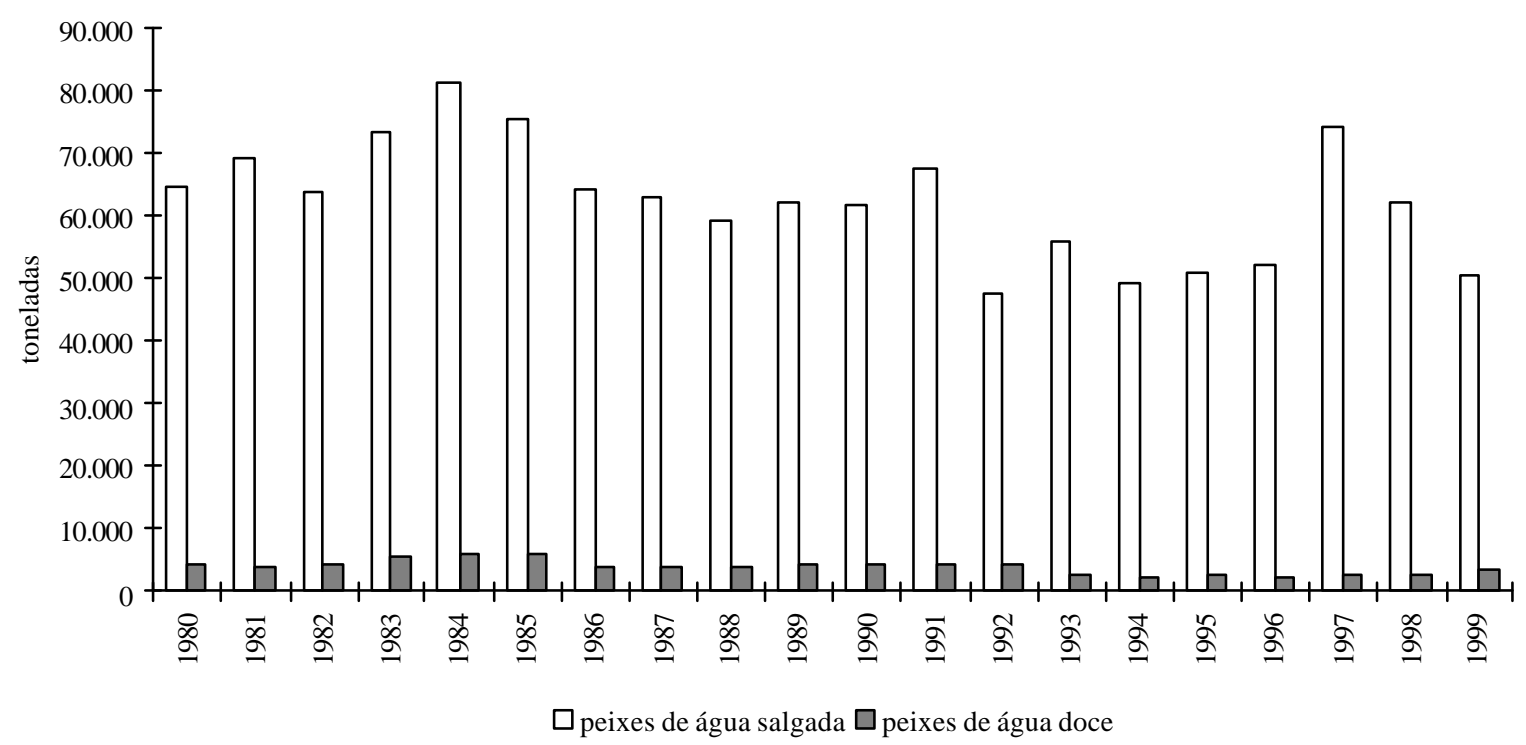

Figura 7 - Quantidade total dos peixes provenientes de água doce e de água salgada comercializados na CEAGESP, 1980 a 1999.

Fonte: Dados de pesquisa obtidos na CEAGESP

Porém, observa-se que o volume de peixes comercializado por ela tem apresentado redução ao longo do tempo. Na soma da quantidade total de peixe que passou por ela entre as décadas de 80 e 90, houve uma redução de 117 mil toneladas (Figura 8).

Grande parte da quantidade comercializada neste entreposto é de peixes de baixo valor. E, na década de 90, esta característica ficou, ainda, mais acentuada. Nesta década, apenas $6,41 \%$ da quantidade total de pescados correspondem a peixes com valor superior à $\mathrm{R} \$ 4,00 / \mathrm{kg}$. Ao se analisar as espécies comercializadas por estrato de preço (Figura 9), observa-se que além de possuírem a maior quantidade comercializada os peixes com valores inferiores a $\mathrm{R} \$ 2,00 / \mathrm{kg}$, também possuem grande variedade de espécies. 


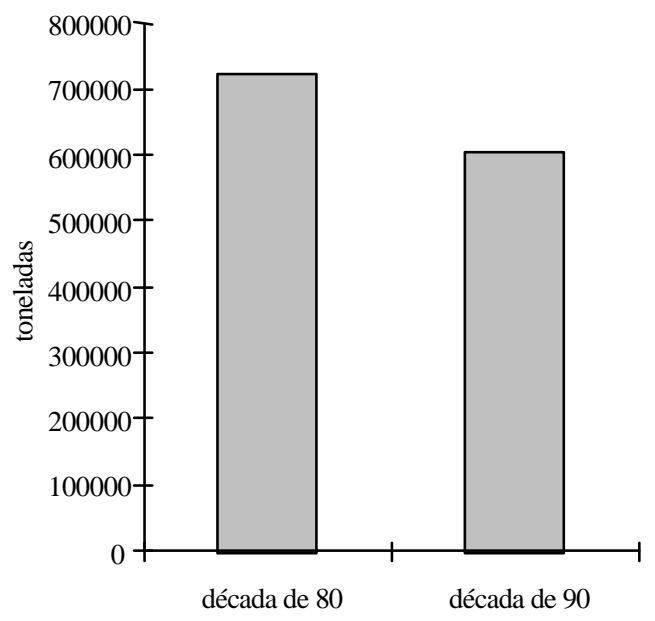

Figura 8 - Quantidade total de pescados comercializados na CEAGESP nas décadas de 80 e 90.

Fonte: Dados de pesquisa obtidos na CEAGESP

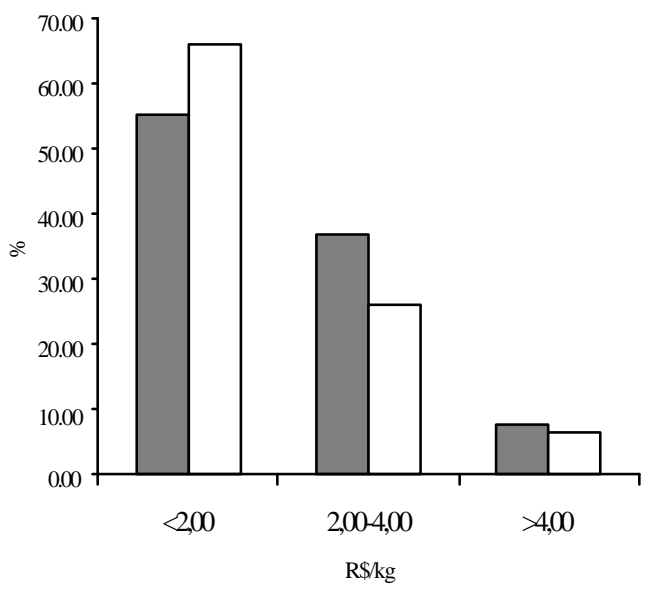

पdécada de 80 पdécada de 90

Figura 9 - Percentual da quantidade de pescados comercializados na CEAGESP nas décadas de 80 e 90, por estrato de preço.

Fonte: Dados de pesquisa obtidos na CEAGESP 
A sardinha é a espécie que merece maior destaque, já que representa 18,88\% da quantidade total comercializada na década de 90 . Ela já foi responsável por $32 \%$ da quantidade comercializada na década anterior. Das espécies de maior valor pode-se destacar o robalo responsável por $48,6 \%$ da quantidade comercializada no estrato de preço $>\mathrm{R} \$ 10,00 / \mathrm{kg}$. O namorado, o pintado e o olhete, que juntos respondem por 70,1\% dos peixes comercializados no estrato de $\mathrm{R} \$ 8,00 / \mathrm{kg}$ a $\mathrm{R} \$ 10,00 / \mathrm{kg}$. O atum e o linguado com $51,1 \%$ e $30,7 \%$, respectivamente no estrato de $\mathrm{R} \$ 8,00 / \mathrm{kg}$ a $\mathrm{R} \$ 6,00 / \mathrm{kg}$ (Quadro 3).

Além de possuir volume mais significativo, a variedade de espécies provenientes de água salgada também é mais abundante que a de água doce. 


\begin{tabular}{|c|c|c|c|c|c|c|c|}
\hline & \multirow[b]{2}{*}{ espécie } & \multicolumn{2}{|c|}{$\%$ da Qtde.Comercializada } & & \multirow[b]{2}{*}{ espécie } & \multicolumn{2}{|c|}{$\%$ da Qtde.Comercializada } \\
\hline & & no extrato & no total & & & no extrato & no total \\
\hline \multirow{5}{*}{ 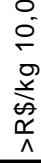 } & robalo & 48,6 & 0,13 & \multirow{11}{*}{ 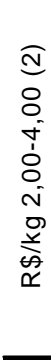 } & chiova & 0,2 & 0,06 \\
\hline & olho de boi & 21,2 & 0,06 & & pescada bicuda & 0,2 & 0,05 \\
\hline & badejo & 18,0 & 0,05 & & batata & 0,1 & 0,03 \\
\hline & pitangola & 12,3 & 0,03 & & barbado & 0,1 & 0,03 \\
\hline & total & 100,0 & 0,28 & & bagre de água doce & 0,1 & 0,02 \\
\hline \multirow{8}{*}{ 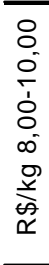 } & namorado & 26,7 & 0,26 & & tombo & 0,1 & 0,02 \\
\hline & pintado & 23,9 & 0,24 & & lacraia & 0,1 & 0,02 \\
\hline & olhete & 19,5 & 0,19 & & sardinha portuguesa & 0,1 & 0,02 \\
\hline & dourado & 12,3 & 0,12 & & pescada olhuda & 0,1 & 0,02 \\
\hline & garoupa & 7,7 & 0,08 & & cavala & 0.0 & 0.01 \\
\hline & cherne & 7,3 & 0,07 & & total & 100,00 & 26,08 \\
\hline & pescada cambucu & 2,6 & 0.03 & & sardinha fresca & 28,6 & 18,88 \\
\hline & total & 100,0 & 0,99 & & corvina & 15,9 & 10,49 \\
\hline \multirow{6}{*}{ 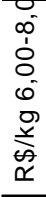 } & atum & 51,1 & 1,31 & & peixe porco & 11,6 & 7,68 \\
\hline & linguado & 30,7 & 0,79 & & mistura & 9,7 & 6,38 \\
\hline & pescada amarela & 10,1 & 0,26 & & pescada goete & 4,8 & 3,16 \\
\hline & pampo & 4,9 & 0,13 & & sardinha congelada & 4,5 & 2,97 \\
\hline & pacu & 3,1 & 0,08 & & pescada maria mole & 4,1 & 2,67 \\
\hline & total & 100,0 & 2,57 & & curimbata & 3,6 & 2,38 \\
\hline \multirow{14}{*}{ 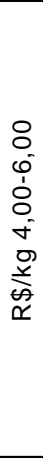 } & merluza & 55,1 & 1,42 & & cavalinha & 2,6 & 1,74 \\
\hline & pescada branca & 16,1 & 0,41 & & betarra & 2,0 & 1,30 \\
\hline & pargo & 11,9 & 0,31 & & bagre & 1,5 & 0,96 \\
\hline & conglio rosa & 3,9 & 0,10 & & castanha & 1,1 & 0,75 \\
\hline & magona & 3,2 & 0,08 & & bonito & 1,1 & 0,71 \\
\hline & cação machote & 2,4 & 0,06 & & pescada tortinha & 1,1 & 0,70 \\
\hline & meca/marlim & 2,3 & 0,06 & & cascote & 0,9 & 0,62 \\
\hline & anequim & 1,6 & 0,04 & & cambeva & 0,8 & 0,54 \\
\hline & quimiji & 0,9 & 0,02 & & mandi & 0,7 & 0,47 \\
\hline & jaú & 0,9 & 0,02 & & tilapia & 0,6 & 0,38 \\
\hline & \multirow{3}{*}{$\begin{array}{l}\text { piapara } \\
\text { tucunaré } \\
\text { dourada }\end{array}$} & 0,8 & 0,02 & o & cação viola & 0,6 & 0,36 \\
\hline & & 0,5 & 0,01 & $N$ & gordinho & 0,5 & 0,36 \\
\hline & & 0,3 & 0,01 & $\underline{x}$ & cação raia & 0,4 & 0,29 \\
\hline & total & 100,00 & 2,57 & $\widetilde{\simeq}$ & xixarro & 0,4 & 0,29 \\
\hline & pescada & 35,4 & 9,23 & $\mathrm{v}$ & savelha & 0,4 & 0,26 \\
\hline & cação & 15,7 & 4,09 & & enguia & 0,3 & 0,22 \\
\hline & cação anjo & 8,2 & 2,15 & & galo & 0,3 & 0,21 \\
\hline & tainha & 7,4 & 1,93 & & sardinha lages & 0,3 & 0,21 \\
\hline & manjuba & 6,9 & 1,79 & & papa terra & 0,3 & 0,20 \\
\hline & abrotea & 5,8 & 1,51 & & parati & 0,3 & 0,19 \\
\hline E & anchova & 5,3 & 1,38 & & vira & 0,2 & 0,13 \\
\hline ㅇ & caçonete & 3,6 & 0,94 & & saguiru & 0,2 & 0,10 \\
\hline 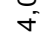 & traíra & 3,2 & 0,84 & & guaivira & 0,1 & 0,07 \\
\hline 용 & berbigão & 1,4 & 0,37 & & jundiá & 0,1 & 0,07 \\
\hline N & piau & 1,2 & 0,32 & & truta & 0,1 & 0,07 \\
\hline 임 & serra & 0,9 & 0,24 & & palombeta & 0,1 & 0,07 \\
\hline के & sororoca & 0,9 & 0,23 & & biru & 0,1 & 0,03 \\
\hline & xerelete & 0,8 & 0,20 & & tambica & 0,0 & 0,03 \\
\hline & trilha & 0,6 & 0,16 & & oveva & 0,0 & 0,01 \\
\hline & xaréu & 0,4 & 0,10 & & chora chora & 0,0 & 0,01 \\
\hline & cascudo & 0,4 & 0,10 & & cação enguia & 0,0 & 0,01 \\
\hline & carapau & 0,3 & 0,07 & & cara & 0,0 & 0,01 \\
\hline & lambari & 0,3 & 0,07 & & total & 100,0 & 65,98 \\
\hline & agulhão & 0,3 & 0,07 & & & & \\
\hline
\end{tabular}

Quadro 3 - Valor percentual da quantidade de pescados comercializados na CEAGESP na década de 90 por espécie e por extrato de preço.

Fonte: Dados de pesquisa obtidos na CEAGESP 
Uma outra característica interessante do mercado da CEAGESP é o comportamento mensal da quantidade de peixes comercializados ao longo do ano. Visualmente, o gráfico de barras representado pela Figura 10 indicam a existência de dois períodos do ano em que a quantidade comercializada é maior, intercalados por dois outros períodos de menor comercialização. O primeiro período de pico de comercialização, que ocorre entre os meses de março e abril, é causada pela elevação na demanda associada à Semana Santa, período em que o consumo de pescados pela comunidade católica é mais elevado. Como consequiência, nesse período, os preços são também mais altos.

O período subseqüente caracteriza-se como sendo de baixa comercialização e estende-se ao longo dos meses entre maio e julho. Trata-se de um período de clima mais frio em que a captura de pescados fica comprometida, portanto com redução na oferta. Além disso, a demanda por pescados neste período é também menor, uma vez que há preferência dos consumidores por alimentos mais energéticos em períodos frios. Assim, nessa época, apesar da redução na oferta, os preços são relativamente mais baixos em relação ao restante do ano (curvas da Figura 10).

Nos meses de agosto a outubro ocorre o segundo período de maior comercialização de pescado na CEAGESP. Este é um período em que a pesca é mais favorável e há preferência por alimentação mais leve, pois com a chegada da primavera, inicia-se o período mais quente do ano. Nessa época, apesar do aumento da demanda, o crescimento da oferta faz com que os preços mantenham-se relativamente baixos.

O último período, entre novembro e fevereiro, é caracterizado como de baixa comercialização. Isso pode ser explicado pela combinação de dois fatores. Do lado da oferta, existe uma redução na captura como resultado do defeso (proibição da pesca no período de desova) de diversas espécies. E, do lado da demanda, as festas de final de ano fazem com que haja aumento no consumo de outros tipos de carne, como as de suínos e aves, em detrimento dos pescados.

Em relação aos preços, os dados da CEAGESP mostram que as espécies de água doce atingem preços superiores em comparação aos preços dos peixes de água salgada. Porém, ao longo das décadas de 80 e 90, os preços dos peixes de água doce apresentam 
nítida tendência de redução. Este comportamento não é tão nítido nos preços dos peixes de água salgada. Outro fator curioso ocorre no mês de dezembro. Os dados da década de 80 mostram um pico nos preços médios nesta época em relação ao mês anterior (Figura 11). Já na década de 90, o mesmo comportamento não é tão visível. Em primeiro lugar, não existe o pico de preços como na década anterior. Em segundo lugar, os preços na década de 90 são significativamente inferiores aos da década de 80 . E, finalmente, a quantidade de peixe comercializado também diminuiu consideravelmente.
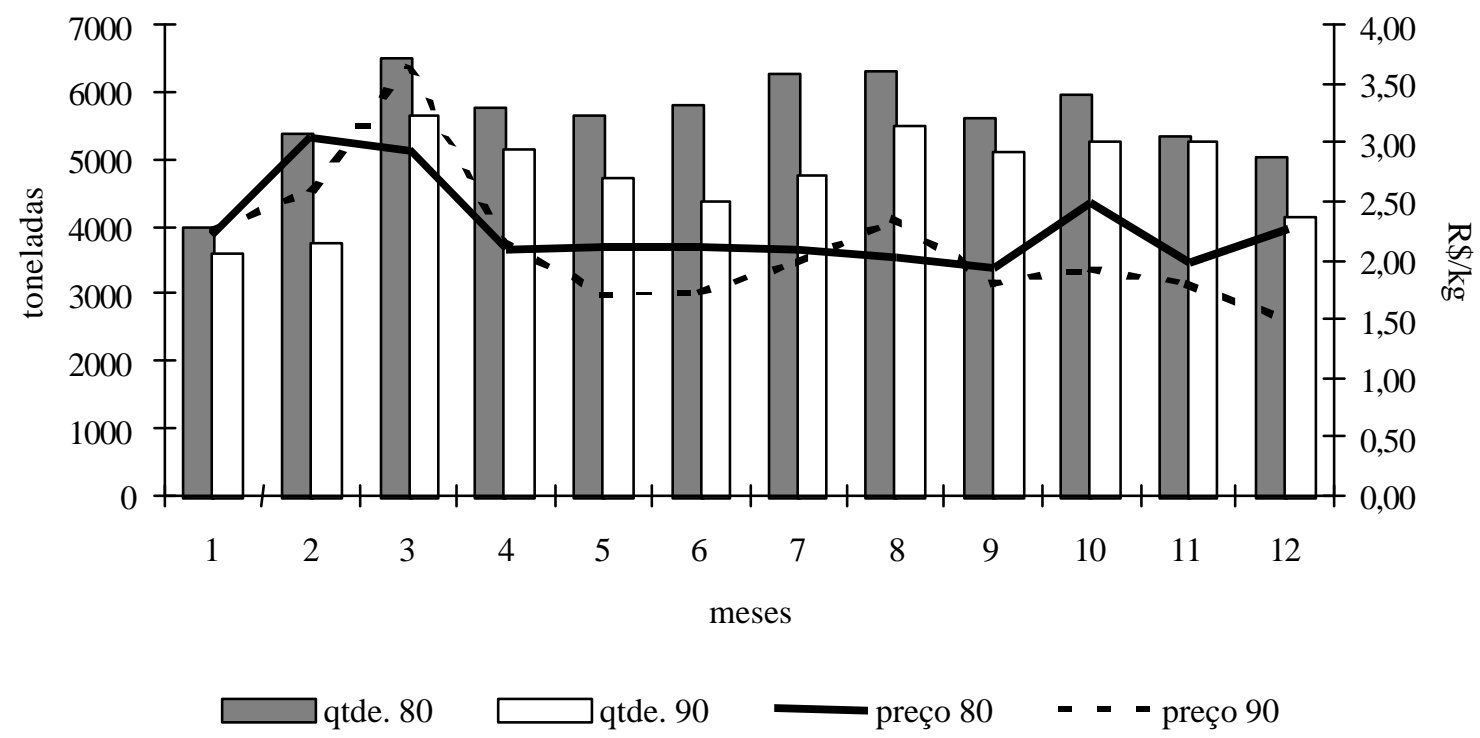

Figura 10 - Médias mensais de quantidade e preço dos peixes provenientes de água salgada comercializados na CEAGESP, nas década de 80 e 90.

Fonte: Dados de pesquisa obtidos na CEAGESP 


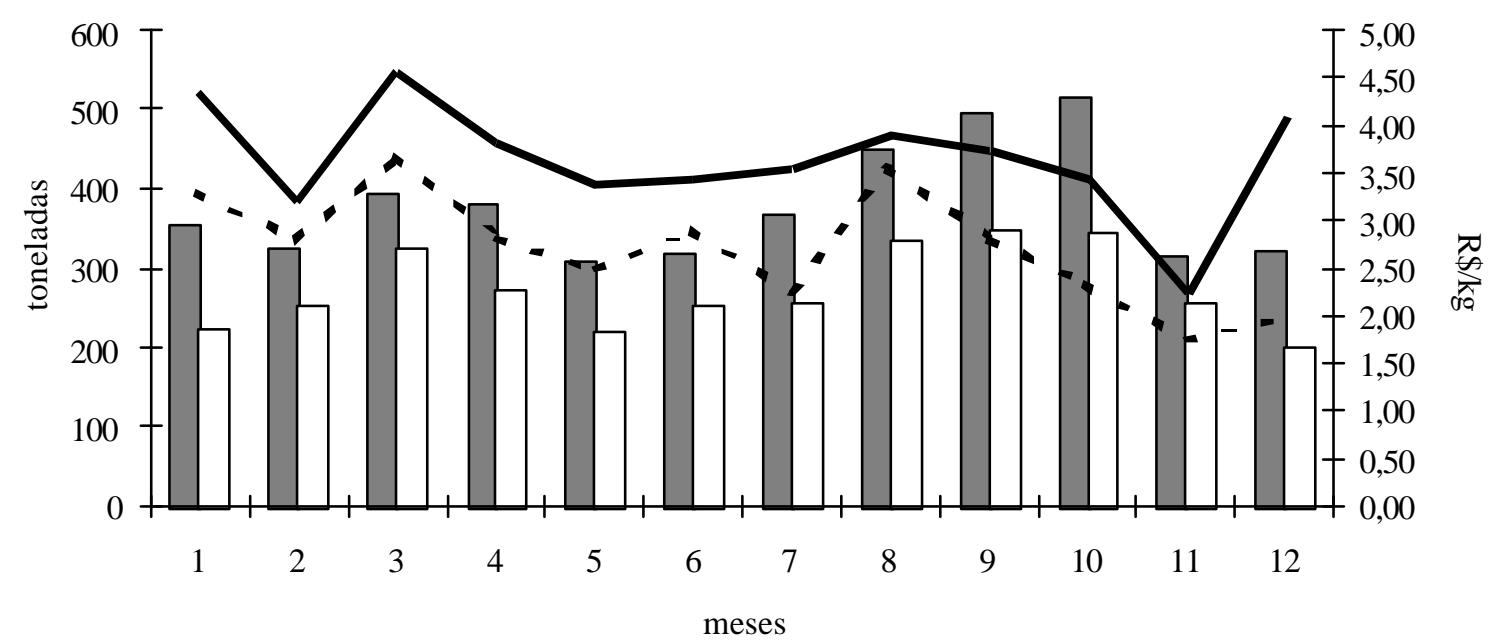

\[ \text { Figura } 11 \text { - Médias mensais de quantidade e preço dos peixes provenientes de água doce } \]
comercializados na CEAGESP, nas década de 80 e 90.

Fonte: Dados de pesquisa obtidos na CEAGESP

\subsection{Mercado Internacional}

Uma outra alternativa de escoamento da produção proveniente da piscicultura é a exportação. O mercado internacional de pescado é muito grande, movimentando anualmente cerca de U\$ 50 bilhões. Do lado da demanda, destacam-se o Japão e os EUA como os maiores consumidores. Por outro lado, a oferta está mais dispersa entre diversos países, destacando-se a Tailândia, Noruega, China, EUA, Dinamarca e Canadá como os maiores exportadores (Quadro 4). 


\begin{tabular}{|lcclcc|}
\hline Importador & 1.000 US\$ & $\%$ & Exportador & 1.000 US\$ & $\%$ \\
\hline Japão & 13.197 .834 & 25,65 & Tailândia & 3.677 .694 & 7,77 \\
EUA & 8.418 .096 & 16,36 & Noruega & 3.368 .909 & 7,12 \\
Espanha & 2.941 .209 & 5,72 & China & 2.648 .325 & 5,60 \\
França & 2.935 .937 & 5,70 & EUA & 2.635 .335 & 5,57 \\
Itália & 2.441 .649 & 4,75 & Dinamarca & 2.581 .036 & 5,45 \\
Alemanha & 2.047 .876 & 3,98 & Canadá & 2.342 .492 & 4,95 \\
Ucrânia & 2.037 .563 & 3,96 & Taiwan & 1.578 .126 & 3,33 \\
Dinamarca & 1.585 .220 & 3,08 & Holanda & 1.561 .207 & 3,30 \\
China & 1.428 .766 & 2,78 & Chile & 1.518 .392 & 3,20 \\
Canadá & 1.198 .175 & 2,33 & Espanha & 1.435 .545 & 3,03 \\
\hline Mundo & 51.447 .249 & 100,00 & Mundo & 47.321 .753 & 100,00 \\
\hline
\end{tabular}

Quadro 4 - Os 10 maiores paises importadores e exportadores de pescados no ano de 1999 em 1000 US\$.

Fonte: Food and Agricultural Organization (2002)

Os mercados norte-americano e europeu remuneram bem o produto ${ }^{6}$. Porém, eles são bastante exigentes, principalmente, em termo de qualidade. A classificação por tamanho de filé, tipos específicos de corte, ausência de off-flavor, certificação internacional do frigorífico, contratos com cláusulas de quantidade, prazos e regularidade de entrega são algumas das exigências mínimas dos importadores. Além disso, uma tendência mais recente é a fiscalização não somente do frigorífico, mas também, da própria produção. Isso é reflexo do aumento da preocupação dos consumidores em relação à procedência do produto, das consequiências sócio-ambientais da produção, etc. Nesse sentido, já estão sendo estudadas formas de certificação da produção no que se refere à produção orgânica, sustentável etc.

Apesar disso, particularmente no caso da tilápia, o mercado internacional parece bastante promissor, principalmente, para os países da Europa e para os EUA. Em período recente, as importações deste último país vêm crescendo constantemente, tendo

6 Em uma estimativa preliminar, com uma taxa de câmbio de cerca de $\mathrm{R} \$ 3,20 / \mathrm{U} \$ 1,00$, os preços pagos por filés de $5 \sim 7$ onças (que podem ser obtidos de peixes entre $850 \sim 1190 \mathrm{~g}$ ) no mercado internacional poderiam remunerar os produtores com preços equivalente aos pagos pelos pesque-pagues. Esses preços são significativamente mais altos do que os pagos pelos frigoríficos atualmente. 
atingido cerca de 100.000 toneladas em 2001. O mercado americano de pescado é segmentado e os principais produtos importados são filés frescos, filés congelados e peixes inteiros congelados.

Em relação ao tamanho, o mercado de filé é dividido em rês categorias: filés de $4 \sim 5$ onças; de $5 \sim 7$ onças; e, de $7 \sim 9$ onças. No período entre 1996 e 2000, não havia diferença significativa entre os preços das diferentes categorias. Porém, a partir de 2001 há indícios de que os preços dos filés de menor tamanho (de $4 \sim 5$ onças) tenham sofrido ligeira desvalorização em relação às demais categorias. Neste ano, os preços eram de cerca de U\$4,41/kg para os primeiros contra cerca de U\$5,95/kg para os filés entre 5 9 onças.

O parque industrial pesqueiro do Brasil já possui processadoras com certificação internacional de exportação para países europeus e norte americanos. Até o presente, este setor limitou-se a processar peixes provenientes da pesca extrativa, principalmente, das espécies de água salgada. Assim, um grande desafio da piscicultura é a organização e adequação da sua produção, principalmente em relação à quantidade, tamanho, qualidade e regularidade de oferta para atender o mercado internacional. 


\section{MATERIAL E MÉTODOS}

Este capítulo foi divido em duas partes. A primeira parte, denominada material, caracteriza a espécie de peixe analisada, os sistemas de criação e a propriedade em que os dados foram coletados. A segunda parte, denominada métodos, foi dividida em dois sub-itens: fundamentos teóricos e metodológicos. O primeiro apresenta, de forma teórica, o problema em que foi baseado o presente trabalho. A seguir, nos fundamentos metodológicos, descreve-se a forma de análise dos dados.

\subsection{Material}

\subsubsection{Espécie de Peixe Analisada}

A tilápia do Nilo ou nilótica, Oreochromis niloticus, é originária dos rios e lagos africanos. Introduzida no Brasil em 1971, inicialmente em açudes do nordeste, difundiu-se para todo o país (Proença e Bittencourt, 1994). A espécie é hoje a segunda mais criada no mundo (Clement e Lovel, 1994).

A tilápia foi escolhida neste estudo pelas seguintes razões (Lovshin, 1997; Popman e Lovshin, 1996):

- Trata-se de uma espécie já domesticada;

- Sua reprodução, assim como as técnicas de reversão sexual são dominadas;

- Existem tecnologias de criação em diferentes sistemas de produção (p.ex., viveiros em terra e tanques-rede) que permite uma ampla distribuição geográfica; 
- A espécie é rústica, com grande poder de adaptação climática;

- Aceita sistemas que exigem grandes concentrações de indivíduos;

- Sua carne pode ser considerada boa em relação a outras espécies de peixe;

- Possui grande aceitação em pesque-pagues;

- Possui boa aceitação no mercado internacional, principalmente o norte americano; e,

- Ainda não é uma espécie que faz parte do hábito alimentar do consumidor nacional.

\subsubsection{Sistema Atual de Produção de Tilápia no Brasil}

De forma sucinta, no sistema atual de produção, o produtor é responsável pela aquisição dos insumos, pela produção e pela comercialização do produto. Ele assume todos os riscos inerentes a atividade.

Em linhas gerais, no sistema de produção em viveiros tradicionais, ou seja, tanques escavados na terra, o produtor é responsável pela aquisição de alevinos e ração. Este último é responsável por 50 a 60\% do custo total de produção (Scorvo et al., 1998; Sonoda et al., 2000b). Neste sistema, espera-se que a primeira fase de cria (até a produção de juvenis) apresente uma elevada taxa de conversão alimentar aparente dos indivíduos. Isso, porque a tilápia é um peixe filtrador que se aproveita do plâncton produzido no tanque. Ou ainda, que as despesas com ração na segunda fase (de juvenil até a despesca), seja menor do que em outros sistemas mais intensivos na medida em que se pode utilizar ração de menor qualidade e, conseqüentemente, mais baratos. Isso é possível por que boa parte do suplemento vitamínico e mineral pode ser obtida através da filtração do plâncton e dos nutrientes dissolvidos na água.

Por outro lado, este sistema apresenta alguns pontos negativos: dificuldade no controle da mortandade, menor homogeneidade do lote, off flavor (gosto de barro na carne) e dificuldade (e maior custo) na despesca. 
Em sistemas mais intensivos, como em tanque-rede, o produtor adquire alevinos de 2 a $3 \mathrm{~cm}$ de comprimento total, que são estocados em altas densidades até a fase de juvenil (10 a $15 \mathrm{~cm})$. Nesta etapa são transferidos para os tanques de terminação. Nestes sistemas a concentração de indivíduos é muito grande e a renovação de água precisa ser constante. Ao contrário do sistema anterior, todos os nutrientes consumidos pelos peixes devem estar contidos na ração. Portanto, ela precisa ser de alta qualidade, sendo conseqüentemente mais cara. (Carneiro et al., 1999). A conversão alimentar aparente neste sistema, geralmente, é pior do que no sistema em viveiros. Como resultado, esses fatores podem ocasionar um custo de produção mais elevado. As vantagens do sistema de tanque-rede são: maior homogeneidade dos peixes, facilidade de despesca, ausência de off flavor (sabor de barro), menor investimento e, a possibilidade de transferir a produção para outros locais. Assim, esse sistema reúne características interessantes tanto para o mercado consumidor como para o produtor.

Portanto, o sistema de produção a ser analisado neste estudo é o de tanques-rede, também chamado de gaiolas. Trata-se de um sistema intensivo de produção de peixes, com renovação contínua de água (Colt e Montgomery, 1991). Além das vantagens já citadas a adoção deste sistema de produção traz outros benefícios, particularmente quando se leva em conta que ele pode ser utilizado com uma infraestrutura mínima e relativamente barata (Balarin e Haller, 1982). A técnica pode ser implantada no mar, estuários, lagos, lagoas e rios tão bem quanto em represas formadas por nascentes, antigos locais de mineração, canais de irrigação, grandes reservatórios, etc. Trata-se de uma excelente alternativa para o aproveitamento racional de corpos d'águas que apresentam dificuldades para a prática da piscicultura convencional (Schimittou, 1993).

O grande potencial hídrico do território brasileiro, estimado em 5,3 milhões de hectares de água doce represada em grandes reservatórios naturais e artificiais, associado a condições climáticas adequadas e disponibilidade de alimentos completos para piscicultura intensiva, pode dar uma idéia do grande potencial da piscicultura em tanques-rede no País (Cyrino et al., 1998; Zanibonni,1997; Carneiro et al., 1999). 


\subsubsection{Caracterização do Sistema de Produção}

Os dados de produção utilizados na presente pesquisa foram obtidos nas safras de 1998 a 2001 da Fazenda Usina Paredão, localizada no município de Oriente, SP. Tratase de uma fazenda cuja principal atividade é a pecuária de corte. Anteriormente, até 1993, a principal atividade da fazenda era a produção e processamento da cana de açúcar. Além da pecuária, também são desenvolvidas as atividades de turismo rural e de pesca esportiva. A piscicultura, neste caso, é uma atividade complementar às demais.

Os dados de produção foram analisados considerando as condições ambientais ${ }^{7}$ que influenciam índices zootécnicos de produtividade $^{8}$. Os tanques-rede foram instalados em duas represas com espelhos d'água de 3,3 e 8,8 ha, respectivamente. A densidade média utilizada em todo o ciclo de produção foi de 236,3 peixes $/ \mathrm{m}^{3}$. A capacidade de sustentação do ambiente foi estimada em $225 \mathrm{~kg} / \mathrm{m}^{3}$. Este valor foi obtido a partir de dados da literatura. O peso médio máximo de $952 \mathrm{~g}$ foi obtido pela divisão da capacidade de sustentação pela densidade média. Praticamente todo o ciclo de produção é feito em tanques-rede, sendo que os alevinos a partir de $5 \mathrm{~g}$ são transferidos para uma rede de malha de multifilamento de nylon alocada dentro do tanque-rede de malha de fios de aço revestido de PVC. A partir dos 100g, é retirada a rede interna e os peixes são soltos no tanque de aço revestido. Os dados de biometria e consumo de ração foram coletados mensalmente durante o período analisado.

Um dos problemas encontrados para a aferição dos dados foi o alto coeficiente de variação encontrado no peso peixes que pode chegar a até $40 \%$. Este alto coeficiente de variação pode ser atribuído a fatores genéticos associados a fatores de manejo. Outro problema é a grande ocorrência de fugas dos peixes na fase em que se encontram na rede interna.

\footnotetext{
${ }^{7}$ Condições ambientais como temperatura da água, oxigênio dissolvido, alcalinidade, dureza, amônio dissolvido etc.

${ }^{8}$ Índices zootécnicos como: conversão alimentar, taxa de crescimento, mortalidade etc.
} 


\subsection{Métodos}

\subsubsection{Fundamentos Teóricos}

\subsubsection{Maximização de Lucro a partir de uma Função de Produção}

A função lucro (L) é definida como a diferença entre a receita obtida com a venda do produto (R) e os custos de produção do sistema (C) (Varian, 1990):

$$
L=R-C
$$

A receita $(\mathrm{R})$, sendo igual ao preço de venda $(\mathrm{P})^{9}$ multiplicado pela quantidade total de produto $(\mathrm{Y})$ :

$$
R=P \cdot Y
$$

$\mathrm{O}$ custo $(\mathrm{C})$, é igual a somatória dos preços de cada insumos $\left(\mathrm{W}_{1}, \mathrm{~W}_{2}, \ldots, \mathrm{W}_{\mathrm{n}}\right)^{10}$ multiplicado por sua respectiva quantidade $\left(\mathrm{X}_{1}, \mathrm{X}_{2}, \ldots, \mathrm{X}_{\mathrm{n}}\right)$, acrescida dos custos fixos (F):

$$
C=\left(X_{1} \cdot W_{1}+X_{2} \cdot W_{2}+\cdots+X_{n} \cdot W_{n}\right)+F
$$

E, a quantidade de produto (Y) pode ser estimada por uma função de produção, tendo como argumentos a quantidade de insumos utilizados $\left(\mathrm{X}_{\mathrm{i}}\right)^{11}$ :

$$
Y=f\left(X_{i}\right)
$$

\footnotetext{
${ }^{9} \mathrm{P} \in \mathrm{R}_{+} \rightarrow \mathrm{P}$ é uma variável exógena

${ }^{10} \mathrm{~W}_{\mathrm{i}} \in \mathrm{R}_{\text {++_- }^{\mathrm{n}}} \rightarrow \mathrm{W}_{\mathrm{i}}$ é uma variável exógena

${ }^{11} \mathrm{X}_{\mathrm{i}} \in \mathrm{R}^{\mathrm{n}}{ }_{+} \rightarrow \mathrm{X}_{\mathrm{i}}$ está sob controle; $\mathrm{e}, \mathrm{f}\left(\mathrm{X}_{\mathrm{i}}\right): \mathrm{R}^{\mathrm{n}} \rightarrow \mathrm{R} \rightarrow \mathrm{f}\left(\mathrm{X}_{\mathrm{i}}\right)$ depende da tecnologia de produção empregada, de fatores ambientais (oxigênio dissolvido, temperatura, $\mathrm{pH}$, etc) e de fatores de manejo (monitoramento, quantidade de ração utilizada, seleção, etc)
} 
Substituindo-se as equações 2, 3 e 4 em 1, obtém-se a seguinte função lucro (L):

$$
L=P \cdot f\left(X_{i}\right)-\left[\left(X_{1} \cdot W_{1}+X_{2} \cdot W_{2}+\cdots+X_{n} \cdot W_{n}\right)+F\right]
$$

Para maximizar a função lucro, deriva-se esta função em relação ao insumo de maior importância no custo de produção, obtemos:

$$
\frac{\partial L}{\partial X_{i}}=P \cdot f^{\prime}\left(X_{i}\right)-W_{i}
$$

Igualando-se a derivada anterior a zero, obtém-se a quantidade de insumo que maximiza o lucro $\left(\mathrm{X}_{\operatorname{máx}} \mathrm{L}\right)$. Ao substituir este valor na função de produção (4) obtém-se a quantidade de produto que maximiza o lucro $\left(\mathrm{Y}_{\text {máx L }}\right)$ :

$$
\frac{\partial L}{\partial X_{i}}=0 \rightarrow X_{\text {máxL }} \rightarrow Y_{\text {máxL }}
$$

Substituindo-se os valores de produção e quantidade de insumos que maximizam o lucro na função lucro (5), mantendo-se os demais parâmetros constantes, obtém-se o ponto que maximiza o retorno do sistema:

$$
L_{\text {máx }}=P \cdot Y_{\text {máxL }}-\left[\left(X_{\text {máxL }} \cdot W+X_{2} \cdot W_{2}+\cdots+X_{n} \cdot W_{n}\right)+F\right]
$$

\subsubsection{Funções de Produção}

Dentre as diferentes funções de produção, uma que se destaca é a da produção de biomassa de peixes em função de seu principal insumo, a ração. A Figura 12 ilustra o crescimento hipotético de tilápias (acúmulo de biomassa no sistema) em função do consumo de ração acumulado. 


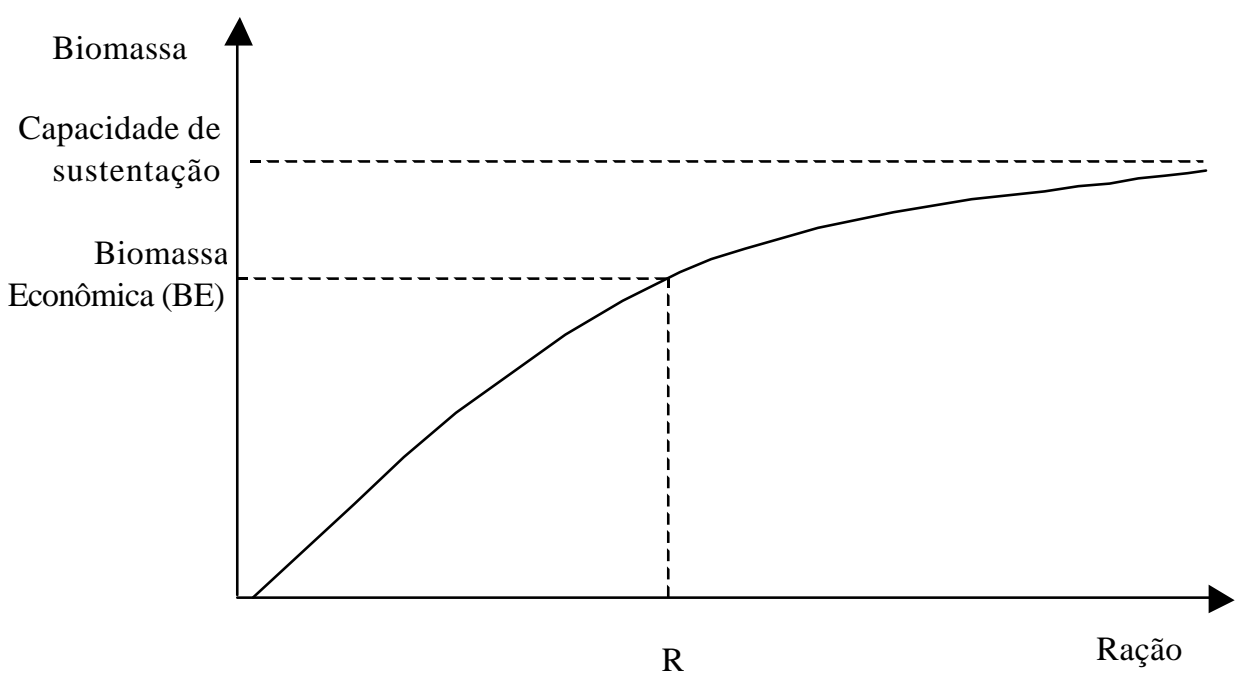

Figura 12 - Curva hipotética do crescimento da biomassa acumulada em função do consumo de ração.

Fonte: Adaptado de Jolly \& Clonts (1993)

O conceito de Capacidade de Sustentação é a biomassa máxima que o sistema de produção suporta (Jolly \& Clonts, 1993). E, Biomassa Econômica, é aquela que maximiza o retorno do sistema e que pode ser determinada a partir da metodologia descrita no item 5.2.1.1. Por se tratar de uma curva de crescimento, existe outra variável importante para a determinação da rentabilidade do sistema, só que, à médio prazo (ao longo da vida útil do projeto) que é o tempo de duração de cada ciclo produtivo. Ele influencia diretamente a produtividade do sistema ao longo do tempo.

A Figura 13 ilustra uma curva hipotética de crescimento da biomassa do sistema em função do tempo. Neste caso o incremento de biomassa é dado pela soma dos ganhos de peso de cada peixe que compõe o sistema. 


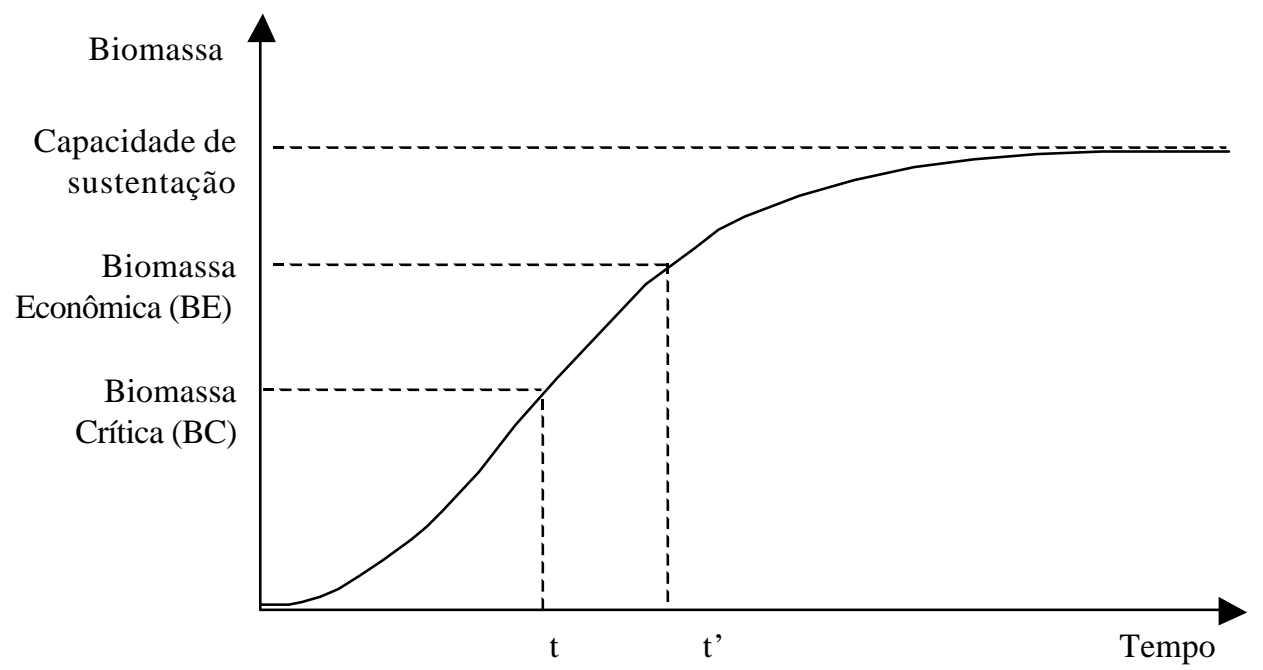

Figura 13 - Curva hipotética de crescimento para produção de determinada espécie de peixe em função do tempo.

Fonte: Adaptado de Jolly \& Clonts (1993)

O conceito de Biomassa Crítica é o ponto de inflexão da curva de crescimento. Ponto no qual os incrementos de ganho de peso passam de crescentes para decrescentes para um mesmo período de tempo (Jolly \& Clonts, 1993).

Pela análise da Figura 12 pode-se inferir que: há incrementos decrescentes de biomassa a medida que o consumo acumulado de ração aumenta. E na Figura 13 considerando o número de peixes constante, observa-se que para atingir uma biomassa maior, ou seja, peixes de maior tamanho, é necessário um ciclo de produção mais longo. Isto implica, no primeiro caso, num maior incremento nos custos de produção a medida que os peixes crescem e no segundo, num menor número de ciclos produtivos durante a vida útil do projeto a medida que os ciclos produtivos se prolongam. Portanto, para otimizar a rentabilidade à curto prazo é necessário calcular o valor da biomassa econômica do sistema. E, para otimizar a rentabilidade a médio prazo é necessário estudar o tempo de duração do ciclo de produção. Uma forma de estuda-lo é iniciar a curva de biomassa em função do tempo com diferentes valores de biomassa e analisar o 
comportamento da rentabilidade a médio prazo. A Figura 14 compara a situações em que inicia-se os ciclos produtivos com diferentes valores de biomassa.

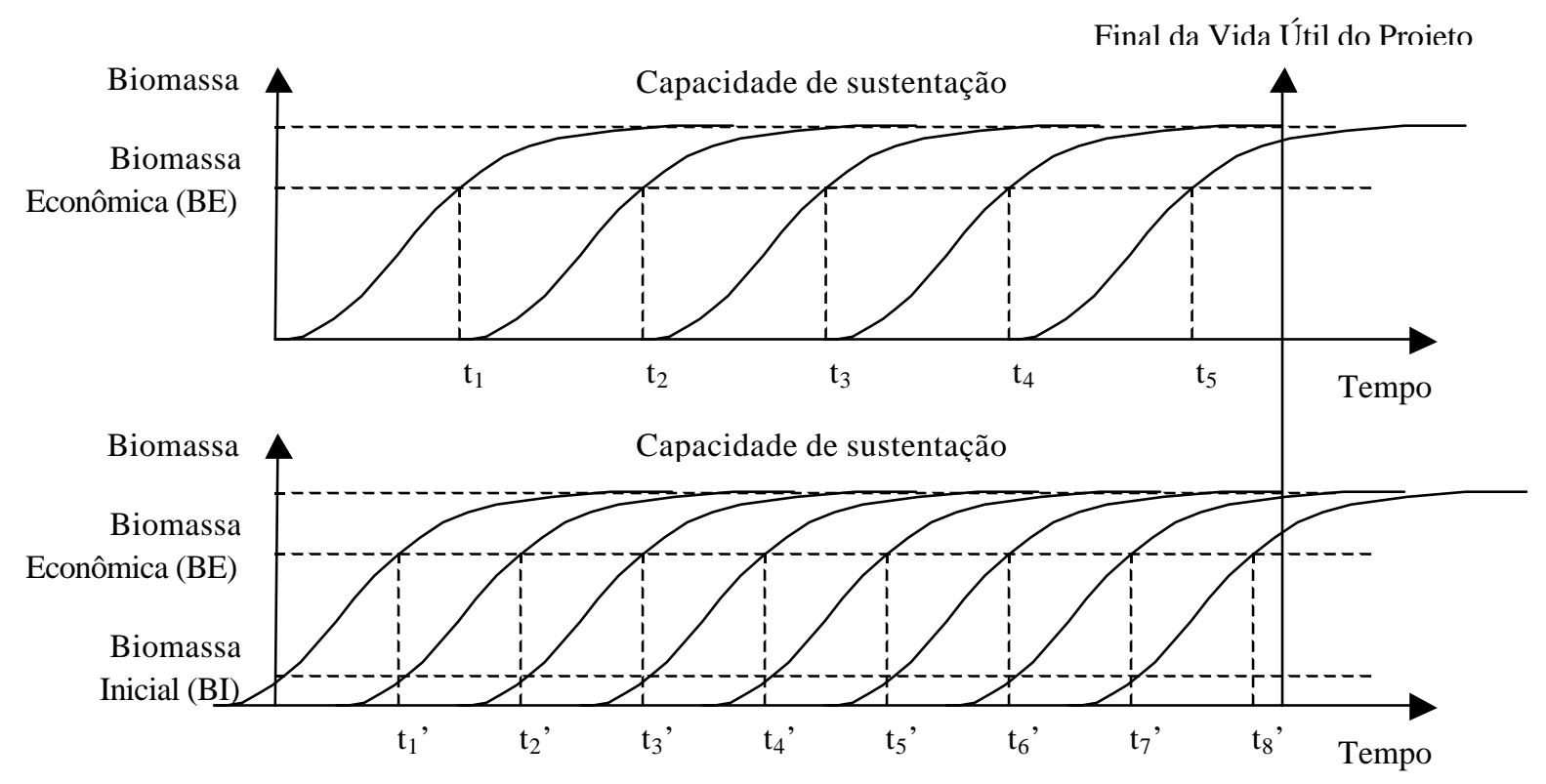

Figura 14 - Número de ciclos produtivos em função do tempo.

Fonte: Adaptado de Jolly \& Clonts (1993)

Observa-se que ao iniciar o ciclo de produção com valores iniciais de biomassa mais elevados, pode-se conseguir um maior número de ciclos produtivos por vida útil do projeto. A partir daí, torna-se necessário avaliar até onde este aumento de produtividade reflete um aumento de rentabilidade para o sistema.

Além da determinação da rentabilidade dos sistemas de produção propostos, também é necessário avaliar sua sensibilidade aos riscos de mercado e de produção. Dentre os riscos de mercado, podemos destacar o preço da ração como sendo o principal do lado dos insumos. E o preço de venda como o principal do lado do produto. Lembrando sempre que para cada mercado que se pretende atingir o comportamento dos preços pode ser bastante distinto. O principal risco de produção seria a mortalidade dos 
peixes durante o ciclo. A combinação destes riscos ao longo do ciclo de produção pode ser decisiva no sucesso ou fracasso do empreendimento.

\subsubsection{Fundamentos Metodológicos}

\subsubsection{Funções de Regressão Utilizadas para Estimar as Curvas de Produção}

$\mathrm{Na}$ determinação das funções de produção a partir dos dados de campo foram utilizados os seguintes formatos de curvas:

\section{a) Função logística}

Hoffmann (1998) apresenta a função logística como:

$$
Y_{i}=\frac{\alpha}{1+e^{-\left(\beta+\gamma \cdot X_{i}\right)}} \cdot \varepsilon_{i}
$$

Onde:

Yi é a variável dependente;

Xi é a variável independente;

$\alpha, \beta$ e $\gamma$ são parâmetros, $\alpha>0$ e $\gamma>0$; e, $\varepsilon_{\mathrm{i}}$ é o erro que se pressupõe proporcional ao valor da variável $\mathrm{Y}_{\mathrm{i}}$.

O parâmetro $\alpha$ representa a capacidade de sustentação da unidade de produção, $\gamma$ está relacionado com a taxa de crescimento da função. E, $\beta$ é um parâmetro de posição, isto é, mudando o valor de $\beta$ enquanto os outros parâmetros são mantidos fixos, a curva apenas se movimenta horizontalmente. A curva logística é radicalmente simétrica em torno de seu ponto de inflexão. A função tem ponto de inflexão para a abscissa $X=-\beta / \gamma$, quando $f(X)=\alpha / 2$ e, neste ponto a derivada da função é máxima. A representação da 
função logística está na Figura 15.

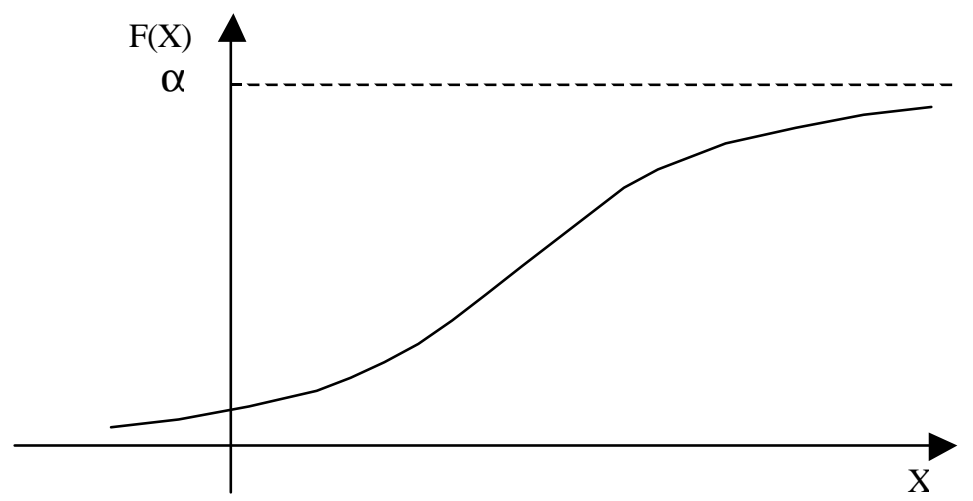

Figura 15 - Representação da função logística.

Fonte: Adaptado de Hoffmann (1998)

Uma das maneiras de se obter as estimativas preliminares de $\beta$ e $\gamma$ é desprezandose o erro de (1), de forma a obter-se $\ln \left[Y_{i} /\left(\alpha-Y_{i}\right)\right]=\beta+\gamma$. $X_{i}$ como é demonstrado abaixo.

$$
\begin{aligned}
& \frac{Y_{i}}{\alpha-Y_{i}}=\frac{\frac{\alpha}{1+e^{-\left(\beta+\gamma \cdot X_{i}\right)}}}{\alpha-\frac{\alpha}{1+e^{-\left(\beta+\gamma \cdot X_{i}\right)}}}=\frac{\alpha}{1+e^{-\left(\beta+\gamma \cdot X_{i}\right)}} \cdot \frac{1}{\frac{\alpha \cdot\left(1+e^{-\left(\beta+\gamma \cdot X_{i}\right)}\right)-\alpha}{1+e^{-\left(\beta+\gamma \cdot X_{i}\right)}}} \\
& =\frac{\alpha}{1+e^{-\left(\beta+\gamma \cdot X_{i}\right)}} \cdot \frac{1+e^{-\left(\beta+\gamma \cdot X_{i}\right)}}{\alpha \cdot\left(1+e^{-\left(\beta+\gamma \cdot X_{i}\right)}-1\right)}=e^{\left(\beta+\gamma \cdot X_{i}\right)} \\
& \therefore \ln \left(\frac{Y_{i}}{\alpha-Y_{i}}\right)=\ln \left(e^{-\left(\beta+\gamma \cdot X_{i}\right)}\right)=\beta+\gamma \cdot X_{i}
\end{aligned}
$$

Esse resultado sugere que, conhecida uma estimativa preliminar de $\alpha$, as estimativas de $\beta$ e $\gamma$ podem ser obtidas ajustando uma regressão linear simples de 
$\ln \left[Y_{i} /\left(\alpha-Y_{i}\right)\right]$ contra $X_{i}$

\section{b) Função de Mitscherlich}

Hoffmann (1998) define a função de Mitscherlich como:

$$
Y_{i}=\alpha \cdot\left[1-10^{-\gamma \cdot\left(X_{i}+\theta\right)}\right]
$$

Onde:

Yi é a variável dependente;

Xi é a variável independente;

$\alpha>0 ;\left|10^{-\gamma}\right|<1 ; \mathrm{e},-\alpha .10^{-\gamma \cdot \theta}<0$.

$\mathrm{O}$ valor da função se aproxima assintoticamente de $\alpha$ quando $\mathrm{X}$ tende para $\mathrm{o}$ infinito. $\mathrm{O}$ parâmetro $\alpha$ corresponde a uma característica biológica da espécie, ou seja, à produção máxima que pode ser alcançada com o fornecimento de um determinado insumo em abundância, que neste caso é a ração. $O$ parâmetro $\theta$ representa a quantidade do insumo disponível no ambiente. E, o parâmetro $\gamma$ é denominado coeficiente de eficácia e está relacionada com a intensidade do efeito da unidade de insumo no desenvolvimento da espécie. A representação gráfica da função Mitscherlich está na Figura 16. 


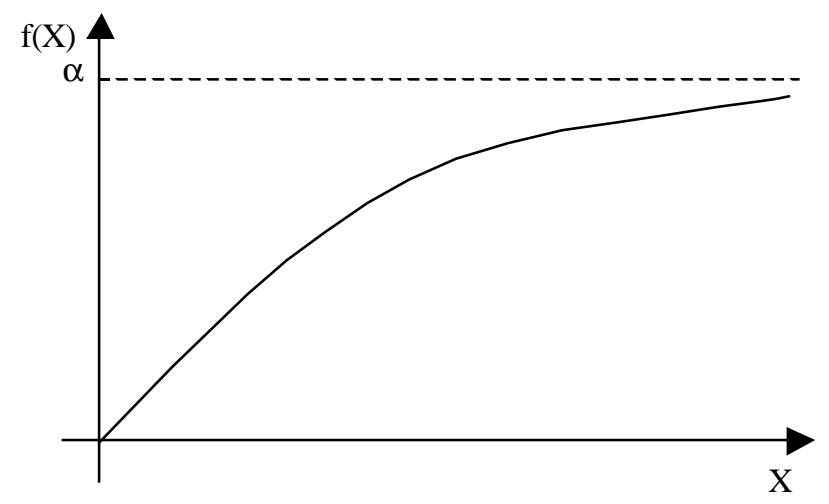

Figura 16 - Representação da função Mitscherlich.

Fonte: Adaptado de Hoffmann (1998)

Os parâmetros $\gamma$ e $\theta$ foram calculados através do método de mínimos quadrados ponderados. Utilizou-se para isto um programa de análise estatística de dados e de regressões denominado Econometric Views 3.0.

\subsubsection{Análise da Viabilidade Econômica do Sistema de Produção}

\section{a) Desembolso (D)}

O desembolso é o mais utilizado pelo produtor. Refere-se as despesas com insumos (ração, alevinos/juvenis), mão de obra, assistência técnica, manutenção de equipamentos, gastos com telefone, etc.

$$
D=R I \cdot P_{R I}+R F \cdot P_{R F}+C A J+O C
$$


Onde:

$$
\begin{aligned}
\mathrm{D}= & \text { Desembolso por ciclo }\left(\mathrm{R} \$ / \mathrm{m}^{3}\right) ; \\
\mathrm{RI}= & \text { Quantidade de ração inicial utilizada }\left(\mathrm{kg} / \mathrm{m}^{3}\right) \text {. Restrição: ração } \\
& \text { utilizada para peixes com peso unitário inferior à } 100 \mathrm{~g} ; \\
\mathrm{P}_{\mathrm{RI}}= & \text { Preço da ração inicial }(\mathrm{R} \$ / \mathrm{kg}) ; \\
\mathrm{RF}= & \text { Quantidade de ração final utilizada por ciclo }\left(\mathrm{kg} / \mathrm{m}^{3}\right) \text {. Restrição: ração } \\
& \text { utilizada para peixes com peso unitário superior à } 100 \mathrm{~g} ; \\
\mathrm{P}_{\mathrm{RF}}= & \text { Preço da ração final }(\mathrm{R} \$ / \mathrm{kg}) ; \\
\mathrm{CAJ}= & \text { Custo do alevino/juvenil por ciclo }\left(\mathrm{R} \$ / \mathrm{m}^{3}\right) ; \text { e, } \\
\mathrm{OC}= & \text { Outros custos como: mão de obra e encargos sociais, manutenção das } \\
& \text { estruturas e veículo, telefone,etc }\left(\mathrm{R} \$ / \mathrm{m}^{3}\right) .
\end{aligned}
$$

Neste trabalho, diferentemente do apresentado por Martin et al. (1994), não está sendo considerado o salário do administrador como parte do desembolso. Em geral, o administrador do negócio é o produtor e o seu salário está diretamente relacionado à rentabilidade da produção. Ou seja, retira uma parcela da margem bruta, que será descrita a seguir, como remuneração ao seu trabalho.

\section{b) Custo Total de Produção (CT)}

No custo total produção está incluído além do desembolso, a depreciação do investimento em estruturas como tanques rede, veículo de transporte, barcos e outras construções e o juros sobre o capital empatado.

$$
C T=D+d p+r_{d p}
$$


Onde:

$$
\begin{aligned}
& \text { CT = Custo total de produção por ciclo }\left(\mathrm{R} \$ / \mathrm{m}^{3}\right) ; \\
& \mathrm{D}=\text { Desembolso por ciclo }\left(\mathrm{R} \$ / \mathrm{m}^{3}\right) ; \\
& \mathrm{dp}=\text { Depreciação do investimento por ciclo }\left(\mathrm{R} \$ / \mathrm{m}^{3}\right) ; \mathrm{e}, \\
& \mathrm{r}_{\mathrm{dp}}=\text { Juros sobre o capital empatado. }
\end{aligned}
$$

\section{c) Receita Total (RT)}

A receita total por ciclo é a remuneração da venda dos peixes e ocorre somente ao final do ciclo produtivo.

$$
R T=B F \cdot P_{V}
$$

Onde:

$$
\begin{aligned}
& \mathrm{RT}=\text { Receita total por ciclo }\left(\mathrm{R} \$ / \mathrm{m}^{3}\right) \\
& \mathrm{BF}=\text { Biomassa final }\left(\mathrm{kg} / \mathrm{m}^{3}\right) ; \mathrm{e} \\
& \mathrm{P}_{\mathrm{V}}=\text { Preço de venda }(\mathrm{R} \$ / \mathrm{kg})
\end{aligned}
$$

\section{d) Margem Bruta (MB)}

A margem bruta é a receita total por ciclo menos o desembolso.

$$
M B=R T-D
$$

Onde:

$$
\begin{aligned}
& \mathrm{MB}=\text { Margem bruta por ciclo }\left(\mathrm{R} \$ / \mathrm{m}^{3}\right) \\
& \mathrm{RT}=\text { Receita total }\left(\mathrm{R} \$ / \mathrm{m}^{3}\right) ; \mathrm{e} \\
& \mathrm{D}=\text { Desembolso }\left(\mathrm{R} \$ / \mathrm{m}^{3}\right)
\end{aligned}
$$


A margem bruta é um índice de rentabilidade um pouco diferente do fluxo de caixa apresentado por Martin et al. (1994), pois não considera os juros sobre capital circulante. Tal taxa encontra-se implícita na taxa interna de retorno (TIR) que será descrita a seguir.

\section{e) Valor Líquido Presente (VLP)}

O Valor Líquido Presente é um índice de rentabilidade que permite analisar a viabilidade econômica do projeto ao longo prazo.

$$
V L P=\sum_{j=1}^{n} \frac{M B j}{(1+r)^{j / 365}}
$$

Onde:

$$
\begin{aligned}
& \text { VLP = Valor líquido presente; } \\
& \mathrm{n}=\text { Número de períodos que representa o horizonte do projeto; } \\
& \mathrm{MB}_{j}=\text { Margem bruta do projeto por ciclo produtivo } \mathrm{j} / 365 ; \\
& \mathrm{j}=\text { duração de um período em dias; } \mathrm{e}, \\
& \mathrm{r}=\text { Taxa de desconto por período. }
\end{aligned}
$$

Para se calcular o VLP, considera-se no ano 1, o valor do investimento total para o início do projeto (I). Para os demais anos, considera-se o fluxo de caixa anual. Este fluxo é desconto uma taxa de desconto de mercado para trazer os valores futuros para o presente. Se a somatória destes valores for maior que zero, então o projeto é economicamente viável (adaptado de Noronha, 1986). Outro indicador que permite avaliar a rentabilidade de projetos é a taxa interna de retorno (TIR). 


\section{f) Taxa Interna de Retorno (TIR)}

A taxa interna de retorno de um projeto é definida como a taxa de desconto $\alpha$ real e não negativa, para a qual se verifica a relação (adaptado de Noronha 1986):

$$
\sum_{j=1}^{n} \frac{M B j}{(1+\alpha)^{j / 365}}=0
$$

Onde:

$$
\begin{aligned}
& \mathrm{n}=\text { Número de períodos que representa o horizonte do projeto; } \\
& \mathrm{MB}_{j}=\text { Margem bruta do projeto por ciclo produtivo } \mathrm{j} / 365 ; \\
& \mathrm{j}=\text { duração de um período em dias; e, } \\
& \alpha=\text { Taxa interna de retorno. }
\end{aligned}
$$

A taxa interna de retorno tem um significado especial neste trabalho, pois nela estão embutidas a remuneração do produtor e os juros sobre capital circulante.

Para tornar esta análise mais completa, também será usado um processo de simulação (conhecida como simulação de Monte Carlo) que incorpora alguns elementos de risco ao processo.

\section{g) Processo de Simulação de Riscos}

Além da análise estatística que considera os valores médios obtidos, o presente estudo visa efetuar uma análise de sensibilidade do projeto utilizando o Método de Monte Carlo. Este método possibilita a simulação de variáveis do projeto, levando-se em consideração as suas distribuições de probabilidade, ao longo da via útil do projeto:

A sequiência de cálculo deste método é a seguinte:

a) identificação da distribuição da probabilidade de cada uma das variáveis relevantes do fluxo de caixa do projeto; 
b) seleção, ao acaso, de um valor para cada variável simulada, a partir de sua distribuição de probabilidade;

c) cálculo do indicador de rentabilidade (no presente caso VLP) do projeto hipotético construído com a utilização das variáveis obtidas no processo de simulação acima; e,

d) repetição do processo até a obtenção de uma distribuição da frequiência do indicador da escolha. A partir desta distribuição é possível estimar a probabilidade de sucesso ou fracasso do projeto.

A qualidade das estimativas das distribuições de probabilidade dos indicadores econômicos determina uma melhor (ou pior) simulação dos possíveis fluxos de caixas. (Noronha, 1986; Chabalin, 1996). 


\section{RESULTADOS E DISCUSSÃO}

\subsection{Determinação das Curvas de Produção}

A primeira curva estimada foi a do peso unitário do peixe em função do empo. Ela nos auxiliou na determinação do tempo de duração do ciclo de produção e permitiu a simulação da duração de cada ciclo produtivo para diferentes pesos de entrada e de venda. Desta forma foi possível saber quantos ciclos produtivos completos foram realizados dentro da vida útil do projeto.

A partir dos dados de campo de peso médio ( $\mathrm{g}$ ) dos peixes e dos seus respectivos dias de coleta, sendo que se considerou como dia zero o início do ciclo produtivo, obtiveram-se os seguintes parâmetros da função:

\begin{tabular}{lccccc|}
\hline & $\alpha$ & $\gamma$ & $\beta$ & $\mathrm{R}^{2^{*}}$ & $\mathrm{~F}^{* *}$ \\
\hline & 952 & 0,0139 & $-4,2512$ & 0,8531 & 1037,94 \\
Estatística t & 32,2171 & $-40,3834$ & & \\
Prob & 0,0000 & 0,0000 & 0,0000 \\
$* \mathrm{R}^{2}=$ coeficiente de determinação \\
$* * \mathrm{~F}$ = análise de variância para regressão com base na estatística "F"
\end{tabular}

Observa-se que tanto a estatística t de Student para os parâmetros $\alpha, \gamma$ e $\beta$ quanto a estatística $\mathrm{F}$ para a função foram significativas para a probabilidade de $1 \%$. Já o $\mathrm{R}^{2}$ de 0,8531 da função mostrou-se satisfatoriamente significativa. Isto demonstra que os parâmetros se ajustaram bem à funç ão de produção estimada. 
Os parâmetros estimados $\alpha, \gamma$ e $\beta$ estão representados algebricamente pela Equação 17:

$$
f(X)=\frac{952}{1+e^{-(0,0139 X-4,2512}}
$$

Onde:

$$
\begin{aligned}
& f(X)=(P) \text { peso unitário do peixe }(g) \\
& X=\text { tempo (dias) }
\end{aligned}
$$

Os dados coletados e a curva representada pela Equação 17 podem ser visualizadas na Figura 17:

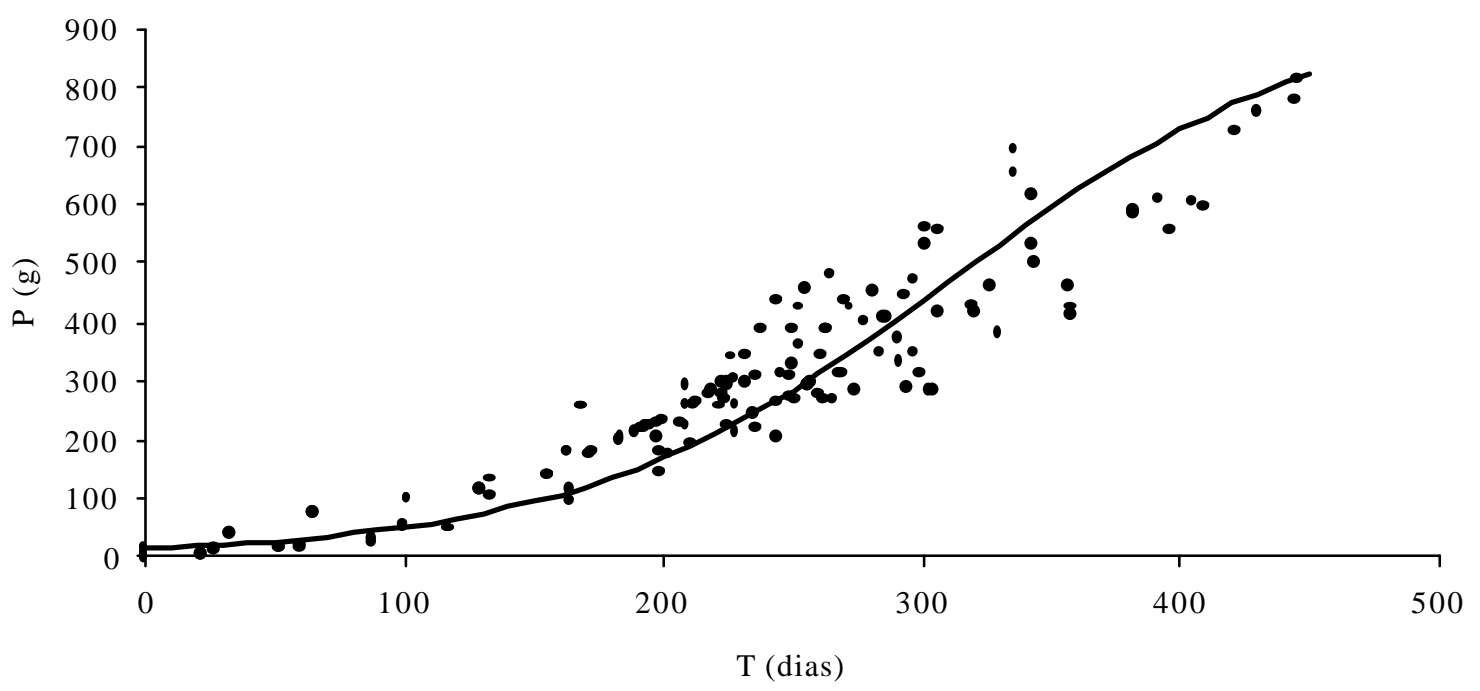

Figura 17 - Curva de peso unitário do peixe (P) em gramas em função do tempo em dias.

Fonte: Dados da pesquisa 
Utilizou-se um recurso indireto para transformar os valores do peso médio unitário dos peixes em gramas, em sua respectiva biomassa equivalente em $\mathrm{kg} / \mathrm{m}^{3}$. Foi estimada uma função em que seu parâmetro representa o valor da densidade média de peixes (peixes $/ \mathrm{m}^{3} / 1000$ ). Apesar de existirem os dados de densidade, eles apresentavam pequenas variações, ocasionadas principalmente pela mortalidade, erros na contagem etc. A partir dos dados da biomassa acumulada dos peixes (kg) relativos ao seu respectivo peso médio (g) obteve-se o seguinte parâmetro:

\begin{tabular}{|lcc|}
\hline & $\mathrm{a}$ & $\mathrm{R}^{2^{*}}$ \\
\hline & 0,2363 & 0,9765 \\
Estatística t & 149,7825 & \\
Prob & 0,0000 & \\
& & \\
$* \mathrm{R}^{2}=$ coeficiente de determinação
\end{tabular}

Observa-se que a estatística t, para o parâmetro "a", é significativa para a probabilidade de $1 \%$ e o $\mathrm{R}^{2}$ da função foi significativa, 0,9765. Portanto, o parâmetro a se ajusta bem à função estimada.

O parâmetro "a" representa uma densidade média de 236,3 peixes $/ \mathrm{m}^{3}$. Este parâmetro está representado algebricamente pela Equação 18:

$$
f(X)=0,2363 \cdot X
$$

Onde:

$$
\begin{aligned}
& \mathrm{f}(\mathrm{X})=(\mathrm{BA}) \text { biomassa }\left(\mathrm{kg} / \mathrm{m}^{3}\right) \\
& \mathrm{X}=(\mathrm{P}) \text { peso unitário do peixe }(\mathrm{g})
\end{aligned}
$$

A Figura 18, representa graficamente os dados de biomassa acumulada e seus respectivos pesos unitários. Também foi representada a curva referente à Equação 18 . 


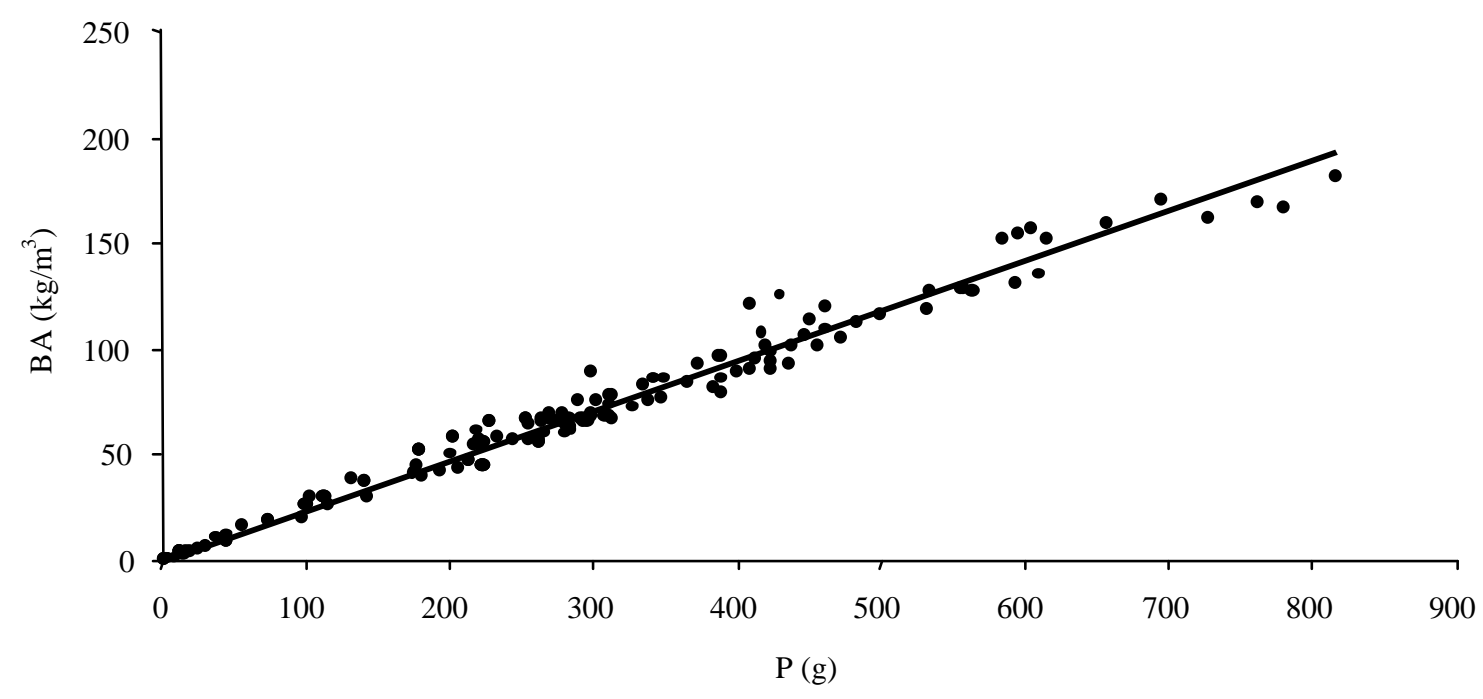

Figura 18 - Curva de biomassa acumulada $(\mathrm{BA}) \mathrm{em} \mathrm{kg} / \mathrm{m}^{3}$ em função do peso unitário do peixe $(\mathrm{P})$ em gramas.

Fonte: Dados de Pesquisa

Os parâmetros estimados a seguir relacionaram os dados de produção de biomassa de peixes e consumo de ração com o período de coleta (dias). A partir dos dados de peso médio ( $\mathrm{g}$ ) multiplicados pela densidade média (peixes $/ \mathrm{m}^{3}$ ) obtida na Equação 18 foram obtidos os dados de biomassa. Estes foram relacionados aos dias de coleta dos pesos e desta forma, obtiveram-se os seguintes parâmetros.

\begin{tabular}{|lccccc|}
\hline & $\alpha$ & $\gamma$ & $\beta$ & $\mathrm{R}^{2 *}$ & $\mathrm{~F}^{* *}$ \\
\hline & 225 & 0,0138 & $-4,2609$ & 0,8727 & 1007,75 \\
Estatística t & & 31,7451 & $-40,4206$ & & \\
Prob & 0,0000 & 0,0000 & 0,0000 \\
$* \mathrm{R}^{2}=$ coeficiente de determinação \\
$* * \mathrm{~F}=$ análise de variância para regressão com base na estatística "F"
\end{tabular}


Observa-se que tanto a estatística t de Student, para os parâmetros $\alpha, \gamma$ e $\beta$, quanto a estatística $\mathrm{F}$, para a função, foram significativas para a probabilidade de $1 \%$. Já o $\mathrm{R}^{2}$ de 0,8727 da função foi significativo. O que demonstra que os parâmetros se ajustaram bem àfunção estimada.

Os parâmetros estimados $\alpha, \gamma$ e $\beta$ estão representados algebricamente pela Equação19:

$$
f(X)=\frac{225}{1+e^{-(0,0138 X-4,2609}}
$$

Onde:

$$
\begin{aligned}
& f(X)=(B A) \text { biomassa }\left(\mathrm{kg} / \mathrm{m}^{3}\right) \\
& X=(T) \text { tempo (dias) }
\end{aligned}
$$

\begin{tabular}{|c|c|c|c|c|}
\hline & $\gamma$ & $\beta$ & $\mathrm{R}^{2^{*}}$ & $\mathrm{~F}^{* *}$ \\
\hline & 0,004925 & 3,757227 & 0,9268 & 2090,39 \\
\hline Estatística t & 22,4087 & 41,1271 & & \\
\hline Prob & 0,0000 & 0,0000 & & 0,0000 \\
\hline
\end{tabular}

Ao relacionar os dados de quantidade de ração consumida, ou acumulada, aos seus respectivos dias de coleta foi possível estimar os seguintes parâmetros:

Neste caso, a estatística t de Student para os parâmetros $\gamma$ e $\beta$ e a estatística F para a função foram significativas para a probabilidade de $1 \%$. Já o $\mathrm{R}^{2}$ de 0,9268 da função demonstrou-se elevado grau de significância. $\mathrm{O}$ que demonstra que os parâmetros se ajustam bem à função estimada.

Os parâmetros estimados $\gamma$ e $\beta$ estão representados algebricamente pela Equação 20: 


$$
f(X)=e^{(3,7572270,004925 X)}-42,83
$$

Onde:

$$
\begin{aligned}
& f(X)=(R A) \text { quantidade de ração }\left(\mathrm{kg} / \mathrm{m}^{3}\right) \\
& X=(T) \text { tempo (dias) }
\end{aligned}
$$

Os dados de biomassa acumulada e de ração acumulada em relação ao seus respectivos dias de coleta e as curvas que representam as Equações19 e 20 podem ser visualizadas graficamente na Figura 19:

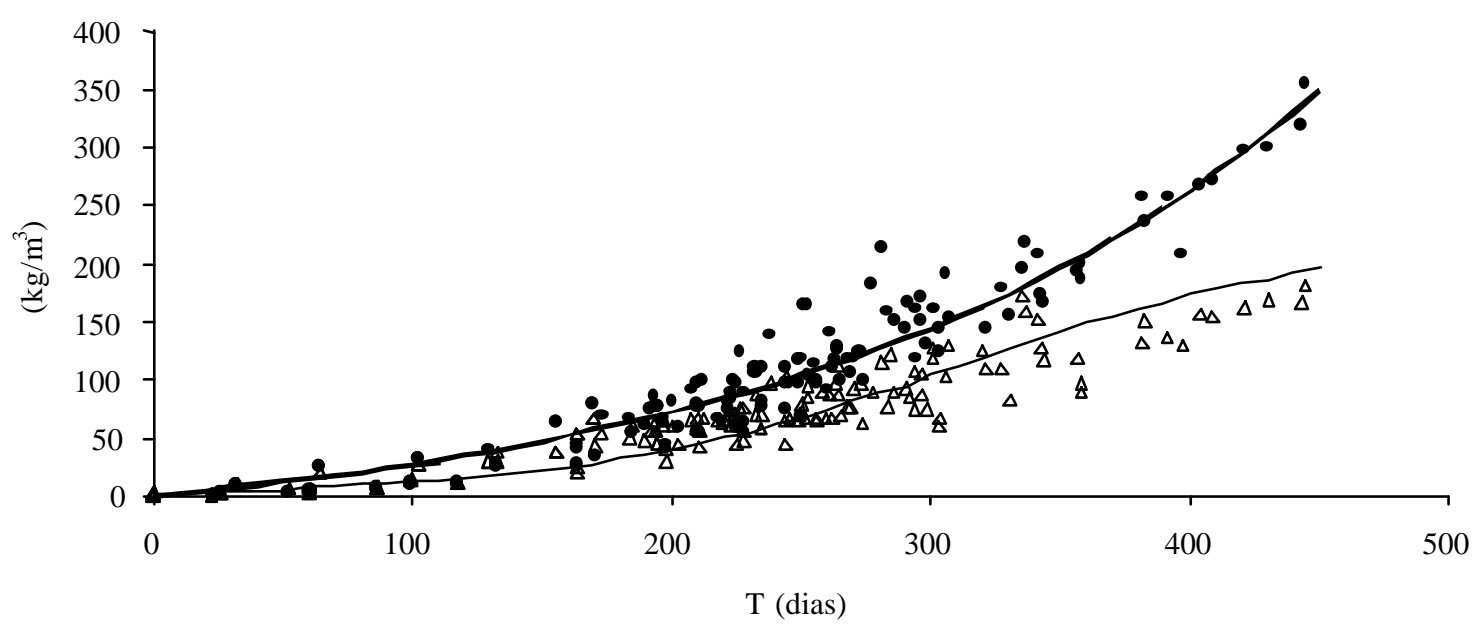

- $\mathrm{RA} \Delta \mathrm{BA} \longrightarrow \mathrm{RA}=\mathrm{f}(\mathrm{T})-\mathrm{BA}=\mathrm{f}(\mathrm{T})$

Figura 19 - Curvas de biomassa acumulada (BA) e quantidade de ração (RA) consumida durante o ciclo de produção em função do tempo de duração do ciclo de produção.

Fonte: Dados de Pesquisa 
$\mathrm{E}$, finalmente, foram estimados os parâmetros que relacionam os dados biomassa acumulada de peixes com a respectiva quantidade de ração consumida. Os parâmetros obtidos foram:

\begin{tabular}{|lcccc|}
\hline & $\alpha$ & $\gamma$ & $\theta$ & $\mathrm{R}^{2 *}$ \\
\hline & 225 & $-0,001698$ & 0 & 0,9157 \\
Estatística t & & $-56,7557$ & & \\
Prob & 0,0000 & & \\
* $^{2}=$ coeficiente de determinação &
\end{tabular}

Observa-se também, que tanto a estatística $t$ de Student para os parâmetros $\alpha, \gamma$ e $\theta$ quanto a estatística $\mathrm{F}$ para a função foram significativas para a probabilidade de $1 \%$. Já o $\mathrm{R}^{2}$ de 0,9157 da função é significativo. $\mathrm{O}$ que demonstra que os parâmetros se ajustam bem à função estimada.

Os parâmetros estimados $\alpha, \gamma$ e $\theta$ estão representados algebricamente pela Equação (21):

$$
f(X)=225 \cdot\left(1-10^{(-0.001698 X)}\right)
$$

Onde:

$$
\begin{aligned}
& \mathrm{f}(\mathrm{X})=(\mathrm{BA}) \text { biomassa }\left(\mathrm{kg} / \mathrm{m}^{3}\right) \\
& \mathrm{X}=(\mathrm{RA}) \text { quantidade de ração consumida }\left(\mathrm{kg} / \mathrm{m}^{3}\right)
\end{aligned}
$$

A curva da Figura 20 representa os dados de biomassa acumulada com suas respectivas quantidades de ração consumidas e a curva referente à Equação (21). 


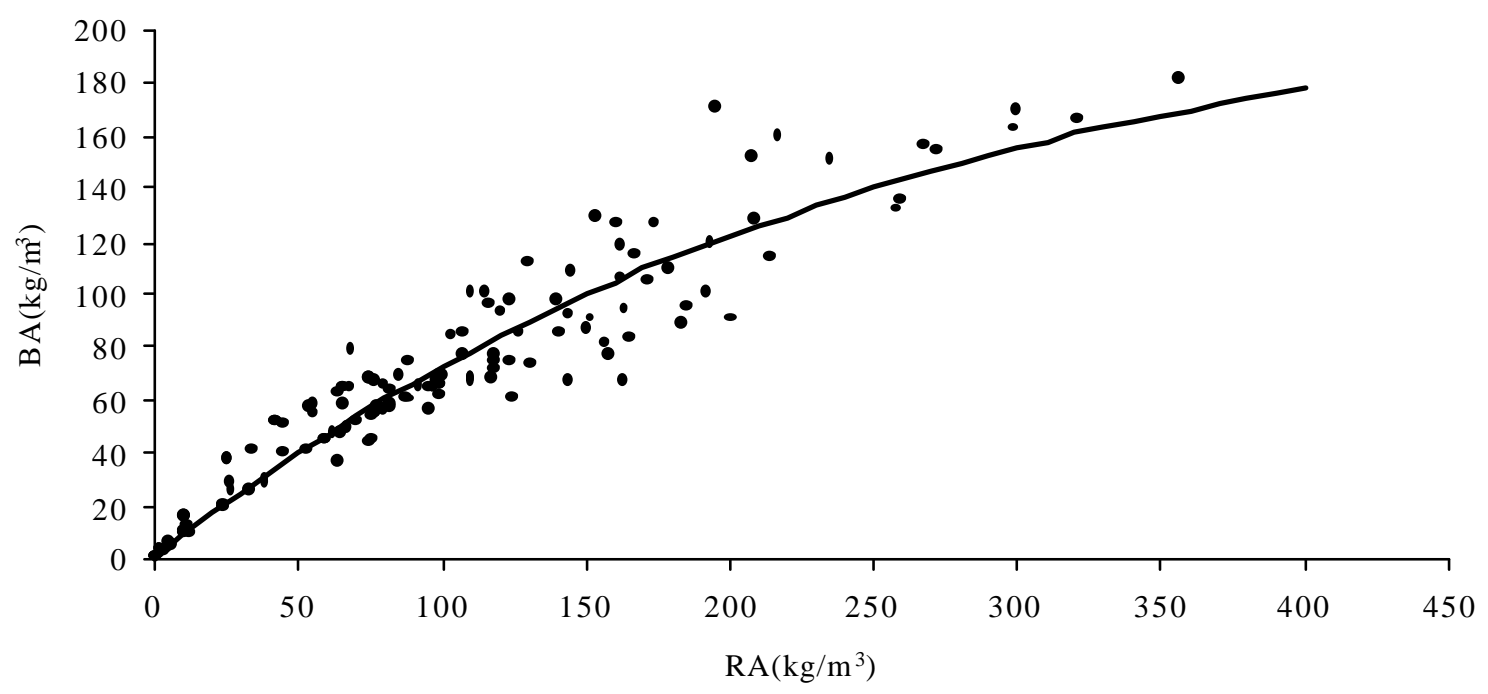

Figura 20 - Curva de biomassa acumulada (BA) em função da quantidade de ração (RA) consumida durante o ciclo de produção.

Fonte: Dados de Pesquisa

A partir da Equação (21) que relaciona a biomassa acumulada com a quantidade de ração consumida foi possível determinar a biomassa econômica do ciclo de produção.

\subsection{Determinação da Biomassa Econômica por Ciclo de Produção}

A partir da função de produção de biomassa em função da ração foi possível encontrar a biomassa econômica do sistema a partir da metodologia acima descrita.

Substituindo (21) em (5), obtém-se (22) e (23):

$$
\begin{gathered}
L=P \cdot B A-W_{R} \cdot R A-F \\
L=P \cdot \alpha \cdot\left(1-10^{(-\gamma \cdot R A)}\right)-W_{R} \cdot R A-F
\end{gathered}
$$


Derivando a função lucro (23) em relação à quantidade de ração utilizada obtémse:

$$
\frac{\partial L}{\partial R A}=-\alpha \cdot P \cdot\left(\frac{\ln 10}{10^{(-\gamma \cdot R A)}}-\gamma\right)-W_{R}
$$

Igualando (24) a zero obtém a quantidade de ração que maximiza o lucro (L):

$$
R A_{\text {máx }}=\frac{\log \left(\frac{W_{R}}{\alpha \cdot P \cdot \ln 10 \cdot \gamma}\right)}{-\gamma}
$$

Substituindo (25) em (23) obtém-se a biomassa econômica (BE):

$$
\begin{gathered}
B E=\alpha \cdot\left(1-\frac{W_{R}}{\alpha \cdot P \cdot \ln 10 \cdot \gamma}\right) \\
B E=225 \cdot\left(1-\frac{W_{R}}{225 \cdot P \cdot \ln 10 \cdot 0,001698}\right)
\end{gathered}
$$

Foram considerados os preços de ração e dos peixes adultos vigentes no mercado de $\mathrm{R} \$ 0,56 / \mathrm{kg}$ e $\mathrm{R} \$ 2,00 / \mathrm{kg}$, respectivamente, e o valor de $\mathrm{F}$ igual a $\mathrm{R} \$ 52,14 / \mathrm{m}^{3}$. A biomassa econômica encontrada para o sistema foi de $153,38 \mathrm{~kg} / \mathrm{m}^{3}$, ou seja, peixes de 650 g numa densidade de 236,3 peixes $/ \mathrm{m}^{3}$ para um L máximo de $\mathrm{R} \$ 90,65 / \mathrm{m}^{3}$. Existe, porém, uma forma menos usual de se encontrar a biomassa econômica, mas que, neste caso, obteve melhor resultado. Utilizando-se as funções de biomassa e ração acumulada em função do tempo, uma função que representa autros custos operacionais que também variam em função do tempo (mão de obra, encargos, assistência técnica, manutenção de estruturas e veículo) e uma parcela que representa o custo operacional que não varia em função do tempo (alevinos). 
Substituindo (19) e (20) em (5), obtém-se (28):

$$
L=P \cdot\left[\frac{225}{1+e^{(-0,0138[=4,2609}}\right]-W_{R} \cdot\left[e^{(3,7572270,00492 \cdot \bar{D})}-42,83\right]-0,055 \cdot T-0,1997
$$

Resolvendo esta função através de substituição de valores de $\mathrm{T}$ (dias) até que se encontre o valor em que L é máximo, obteve-se que a biomassa econômica foi de 173,66 $\mathrm{kg} / \mathrm{m}^{3}$, para um peso unitário de $735 \mathrm{~g}$, no tempo de 401 dias e um L máximo de $\mathrm{R} \$$ $109,40 / \mathrm{m}^{3}$.

\subsection{Determinação da Rentabilidade do Sistema de Produção}

As análises foram baseadas a partir das curvas de produção aferidas acima e dos dados sobre mercado também já descritos. Além destes dados foram utilizados os dados referentes ao fluxo de caixa da Fazenda Usina Paredão. Nela foi investido ao longo de três anos o valor de $\mathrm{R} \$ 36.446,44$ (deflacionados para 2001) para a instalação de 330,20

$\mathrm{m}^{3}$ de tanques-rede mais: veículo de transporte, barcos, e construções de instalações. O valor dos outros custos operacionais, exceto ração e alevinos, foi de $\mathrm{R} \$ 17.219,38$ ao ano e engloba gastos com: funcionários, assistência técnica, telefone e com a manutenção do veículo e das instalações. Desta forma obteve-se um investimento de $\mathrm{R} \$ 110,40 / \mathrm{m}^{3}$ e um gasto com outros custos operacionais (OC) de $\mathrm{R} \$ 52,14 / \mathrm{m}^{3}$ ao ano. Para os cálculos de depreciação e valor líquido presente (VLP) foram considerados uma taxa de $12 \%$ ao ano e uma vida útil de 5 anos para o projeto. $\mathrm{O}$ custo de ração (CRA) foi o preço da ração multiplicado pela quantidade utilizada. O preço da ração considerado foi de $\mathrm{R} \$ 0,80 / \mathrm{kg}$ para peixes de até $100 \mathrm{~g}$ e de $\mathrm{R} \$ 0,56 / \mathrm{kg}$ para peixes com peso superior a $100 \mathrm{~g}$. O desembolso (D) foi a soma do custo com alevinos (CAJ), custo de ração (CRA) e outros custos operacionais (OC). O custo de alevinos foi obtido através da multiplicação do preço do alevino ( $\mathrm{R} \$ 65,00 / \mathrm{mil})$ pela quantidade utilizada por $\mathrm{m}^{3}\left(236,3\right.$ peixes $\left./ \mathrm{m}^{3}\right) \mathrm{e}$ por um fator relacionado às perdas $(30 \%)$. No custo total de produção foram somados o 
desembolso (D) com a depreciação acrescida de juros $\left(d p+r_{d p}\right)$. Foram aferidas as curvas dos diferentes custos de produção acumulados em função do tempo. Desta forma foi possível observar o comportamento do custo ao longo de um ciclo de produção e também ao longo de sua vida útil. Portanto, o texto acima poder ser expresso através das seguintes equações:

$$
\begin{gathered}
C T_{t}=C A J_{t}+C R A_{t}+O C_{t}+\left(d p+r_{d p}\right)_{t} \\
C T_{t}=19,97+\left\{\begin{array}{l}
\mathrm{se} \mathrm{P}<100 \mathrm{~g} \rightarrow 0,8 \cdot\left(e^{(3,757227+0,004925 . t)}-42,83\right) \\
\operatorname{se} \mathrm{P}>100 \mathrm{~g} \rightarrow 39,2+0,56 \cdot\left(e^{(3,757227+0,004925 . t)}-91,83\right)
\end{array}\right. \\
+ \text { 0,143.t }+ \text { 0,0605.t. }(1,12)^{t / 365}
\end{gathered}
$$

As equações 29 e 30determinam o custo total de produção acumulado por $\mathrm{m}^{3}$ diário, logo, tempo (t) foi expresso em dias.

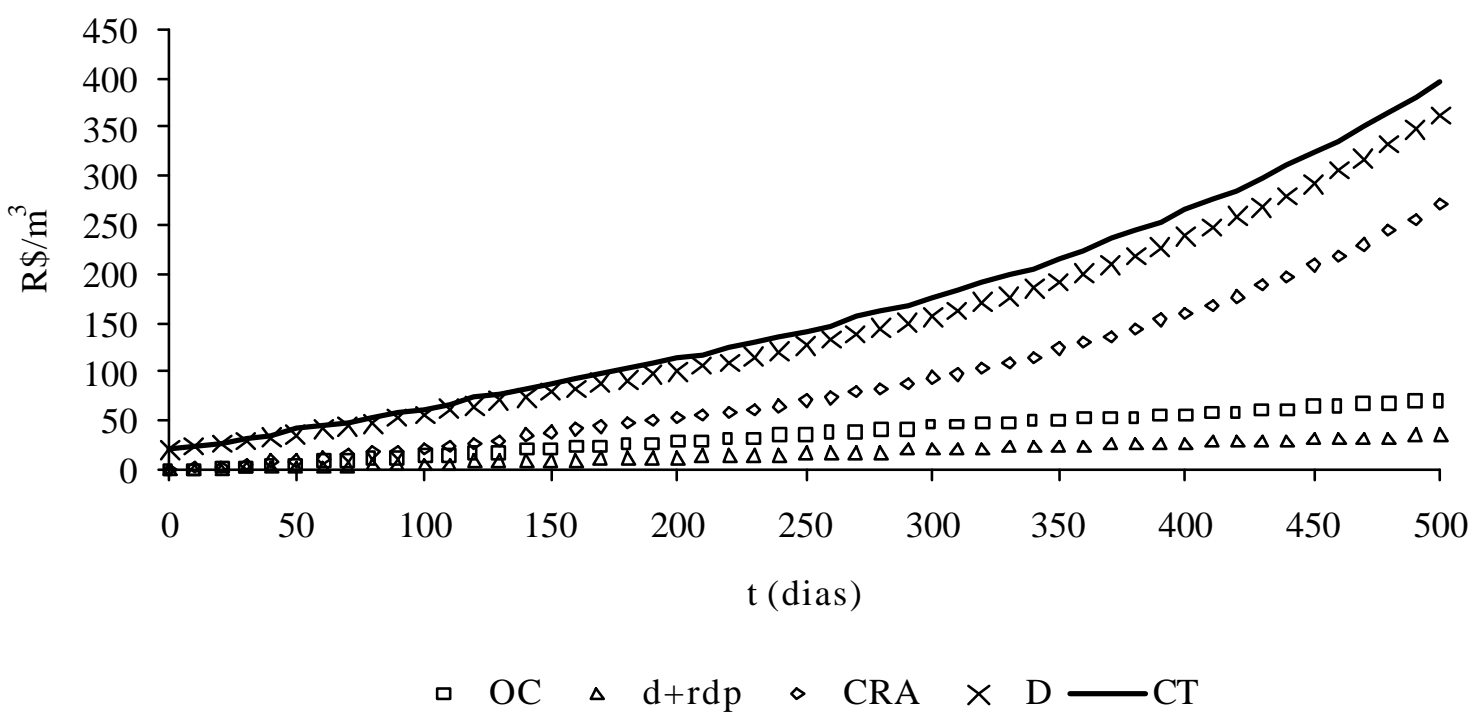

Figura 21 - Comportamento dos diferentes custo de produção acumulados em função do tempo.

Fonte: Dados de Pesquisa 
Para análise de maximização do lucro foi detectado um problema em relação ao tamanho dos peixes no inicio do processo produtivo. O tamanho de entrada dos peixes é um dos fatores que determina o tempo de duração do ciclo de produção, e, portanto, o número de ciclo de produção durante a vida útil do projeto. Por isso, além de determinar o peso ideal de saída como foi feito na determinação da biomassa econômica, também foi importante saber qual a economia que diferentes pesos de entrada trariam ao sistema.

Estimou-se custo de produção para alevino/juvenil (CAJ) de diferentes tamanhos. No sistema atual de produção, o piscicultor adquiriu os alevinos com peso entre 0,5 a 20 g e criou os peixes até o peso de 450 a 800 g dependendo das condições de mercado. Portanto, para que o preço do alevino/juvenil ofertado por um suposto recriador seja interessante para o produtor convencional, considerou-se que:

$$
P A J=\operatorname{máx}\left(\frac{C T}{B A}, P V\right)
$$

Onde:

$\mathrm{PAJ}=$ Preço do alevino/juvenil $(\mathrm{R} \$ / \mathrm{kg})$;

$\mathrm{CT}=$ Custo total de produção $\left(\mathrm{R} \$ / \mathrm{m}^{3}\right)$;

$\mathrm{BA}=$ Biomassa acumulada $\left(\mathrm{kg} / \mathrm{m}^{3}\right) ; \mathrm{e}$,

$\mathrm{PV}=$ Preço de venda $(\mathrm{R} \$ / \mathrm{kg})$.

Ou seja, o preço do alevino/juvenil (PAJ) seja o maior entre o custo de produção total do piscicultor e o preço de venda do peixe adulto (Figura 22). 


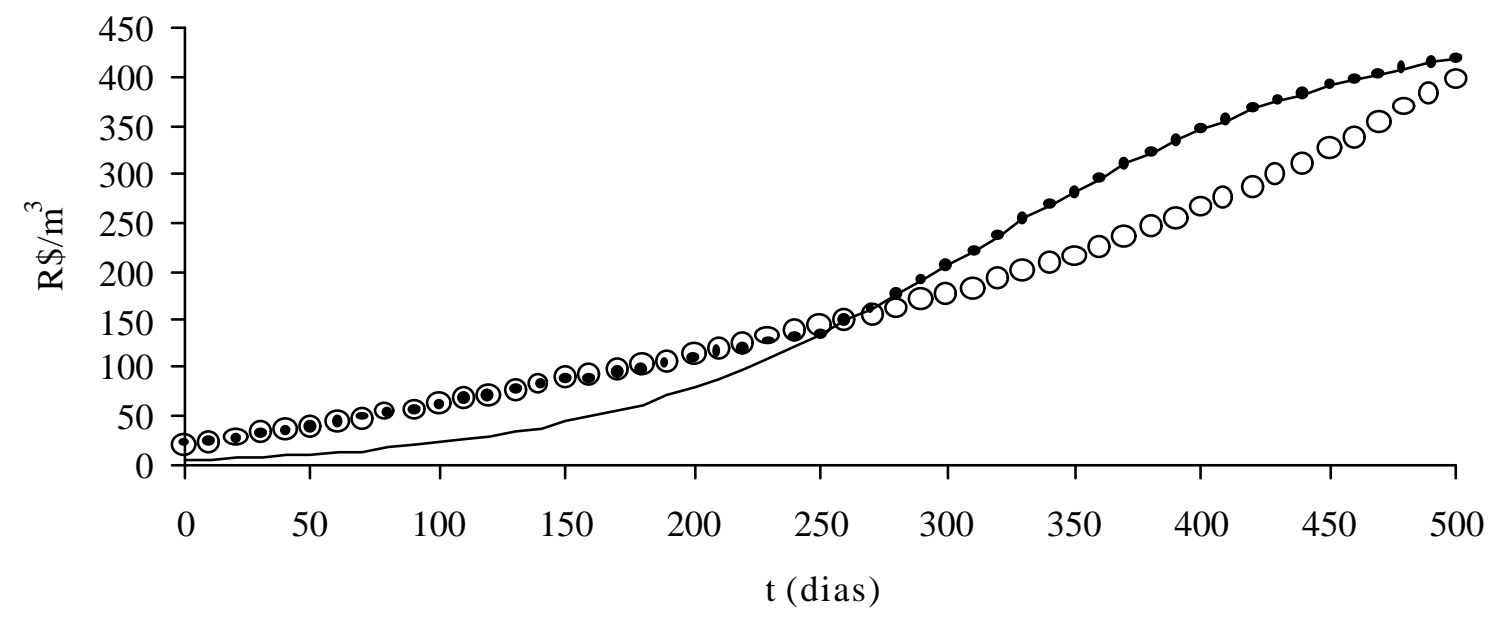

- $\mathrm{CAJ}-\mathrm{RT} O \mathrm{CT}$

Figura 22 - Comportamento da Receita total (RT), custo operacional total (CT) e custo do alevino/juvenil (CAJ) em função do tempo.

Fonte: Dados de Pesquisa

A receita total (Equação 32)em função do tempo $\left(\mathrm{RT}_{\mathrm{t}}\right)$, em $\mathrm{R} \$ /$ dia, foi obtida pela multiplicação da função de biomassa $\left(\mathrm{kg} / \mathrm{m}^{3} /\right.$ dia) pelo preço de venda (PV), em $\mathrm{R} \$ / \mathrm{kg}$. O preço de venda considerado neste modelo foi o preço pago aos produtores que fornecem peixes para os pesque-pagues $(\mathrm{R} \$ 2,00 / \mathrm{kg})$.

$$
R T_{t}=P V \cdot \frac{225}{1+e^{(-0,0138+4,2609}}
$$

Esperou-se que o recriador, por ser especializado na atividade de recria, fosse mais eficiente que o produtor convencional (redução de fugas, aquisição de ração, redução da capacidade ociosa do tanques) e assim com condições de ofertar um produto cujo preço fosse menor ou igual ao custo de produção convencional. A Figura 23 ilustrou o comportamento esperado do preço de aquisição dos alevinos/juvenis para o produtor de peixes adultos. 


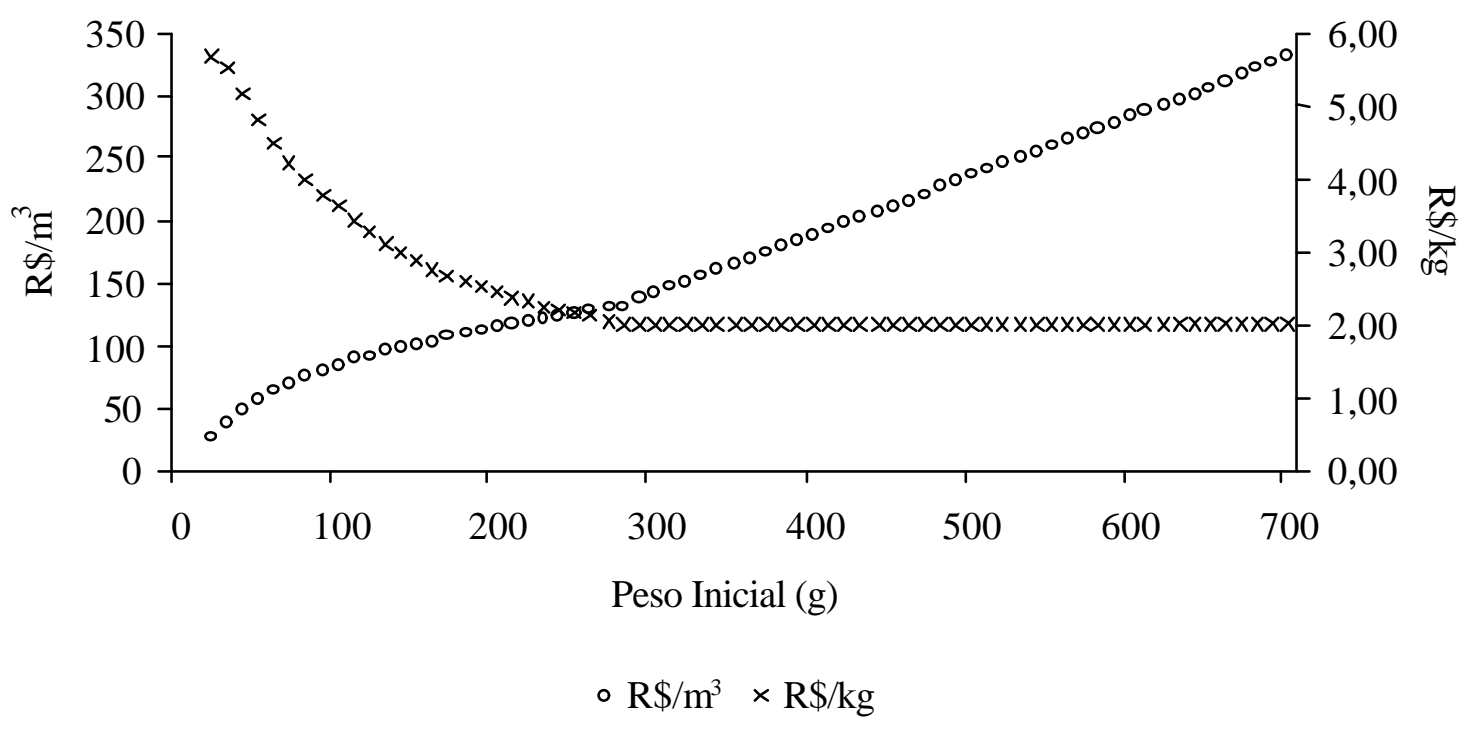

Figura 23 - Comportamento do Custo do alevino/juvenil (CAJ) em R $\$ / \mathrm{m}^{3}$ e $\mathrm{R} \$ / \mathrm{kg}$ em função de seu Peso Inicial (g).

Fonte: Dados de Pesquisa

Considerando estes componentes do custo operacional total e da receita total, foi elaborada uma análise de rentabilidade considerando diferentes pesos de entrada dos alevinos/juvenis respeitando as curvas de produção propostas no modelo. $\mathrm{O}$ peso de venda proposto foi de 700g. De acordo com dados coletados junto aos produtores, esperava-se que numa fase inicial, ou seja, peixes até 100g, as perdas fossem de aproximadamente $30 \%$. Esta porcentagem elevada de perdas foi justificada principalmente por fugas. Também foi considerado um índice de perdas de $10 \%$ ao longo do ciclo. As perdas para peixes acima de $100 \mathrm{~g}$ e peixes terminados ocorreram principalmente devido à mortalidade durante o ciclo de produção que se agravou durante o processo de despesca. Algumas restrições de mercado e de reposição de alevinos/juvenis também foram impostas ao modelo. A restrição de mercado imposta foi a não comercialização de peixes adultos nos meses de maio, junho e julho. Isto se deve ao fato de que em épocas frias a mortalidade dos peixes durante o transporte é elevada e 
pela diminuição da freqüência de pescadores nos pesque-pagues neste período do ano. Para a reposição de alevinos, considerou-se que nos meses de junho, julho e agosto não há reposição. A justificativa foi dada pela elevada mortalidade dos peixes jovens por doenças em períodos frios, após sofrer o estresse do transporte. Considerou-se também que o tempo necessário para a venda e reposição dos alevinos/juvenis foi de 2 meses.

A Figura 24 mostrou a influência que o tamanho inicial do peixe teve sobre o tempo de duração do ciclo de produção no modelo proposto. Por esta Figura foi possível observar que ao iniciar o ciclo de produção com peixes maiores, o tempo de duração de cada ciclo diminui e conseqüentemente aumentou o número de ciclos por vida útil do projeto. Considerando que a produção ao final de cada ciclo de produção foi a mesma, ao se aumentar o número de ciclos de produção por vida útil, elevou-se também a produtividade do sistema.

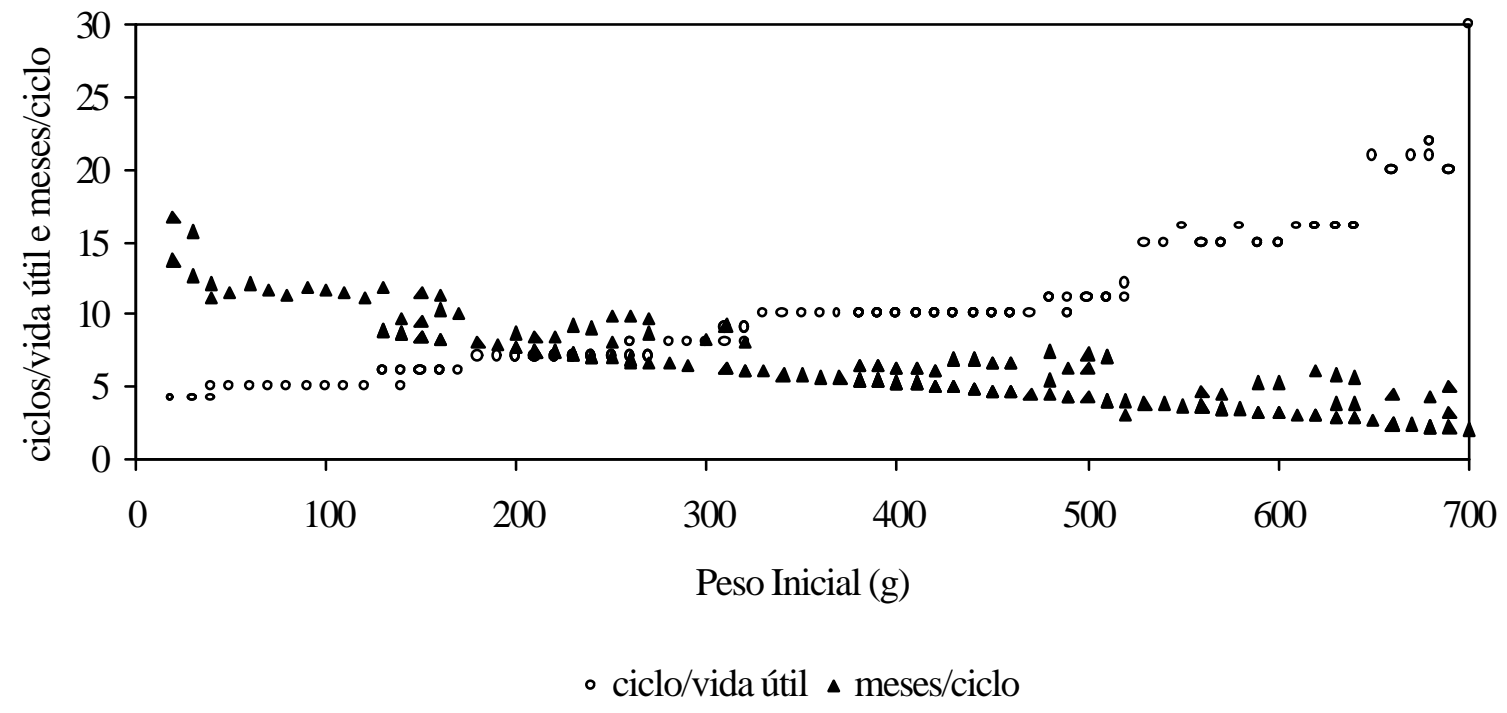

Figura 24 - Número de ciclos de produção por vida útil e tempo de duração de cada ciclo de produção em função do tamanho de entrada do alevino/juvenil.

Fonte: Dados de Pesquisa

A situação atual foi representada pelo valor de peso inicial de $20 \mathrm{~g}$, ou seja, o valor mais a esquerda do gráfico. O tempo de duração de cada ciclo de produção variou entre 14 e 17 meses, o que equivale a 4 ciclos por vida útil. 
A seguir foi realizada uma análise dos indicadores de rentabilidade para a situação descrita acima. Esta análise foi feita para se detectar qual seria o Peso Inicial (g), seguindo as pressuposições impostas ao modelo, que proporcionaria a maior rentabilidade ao produtor de peixes adultos. Para isso, foram usados três indicadores: a Margem Bruta, o Valor Líquido Presente e a Taxa Interna de Retorno para diferentes Pesos Iniciais de peixes. As demais condições foram mantidas constantes para esta análise.

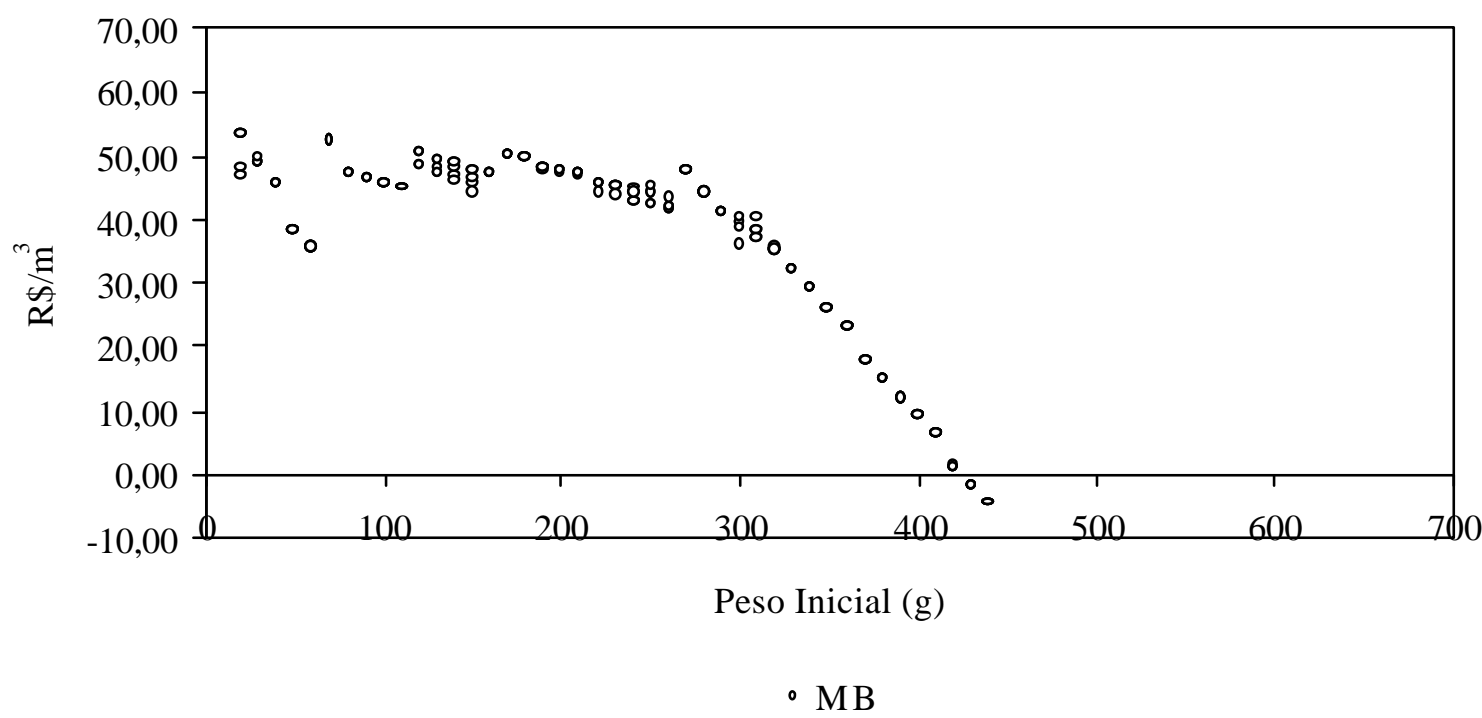

Figura 25 - Comportamento da Margem bruta (MB) em função do Peso Inicial (g) do alevino/juvenil.

Fonte: Dados de Pesquisa

A Figura 25 demonstrou que até $280 \mathrm{~g}$ houve uma leve tendência de redução da Margem Bruta do sistema a medida que Peso Inicial dos peixes aumentava. Esta redução se tornou mais acentuada na aquisição de peixes acima de $280 \mathrm{~g}$.

As Figura 26 e Figura 27 mostram o comportamento do Valor Liquido Presente (VLP) e da Taxa Interna de Retorno (TIR) para diferentes tamanhos de entrada dos peixes. Ambos os indicadores consideram a Margem Bruta e uma taxa de juros anual, além do número de ciclos produtivos para um determinado tempo de vida útil do projeto. 


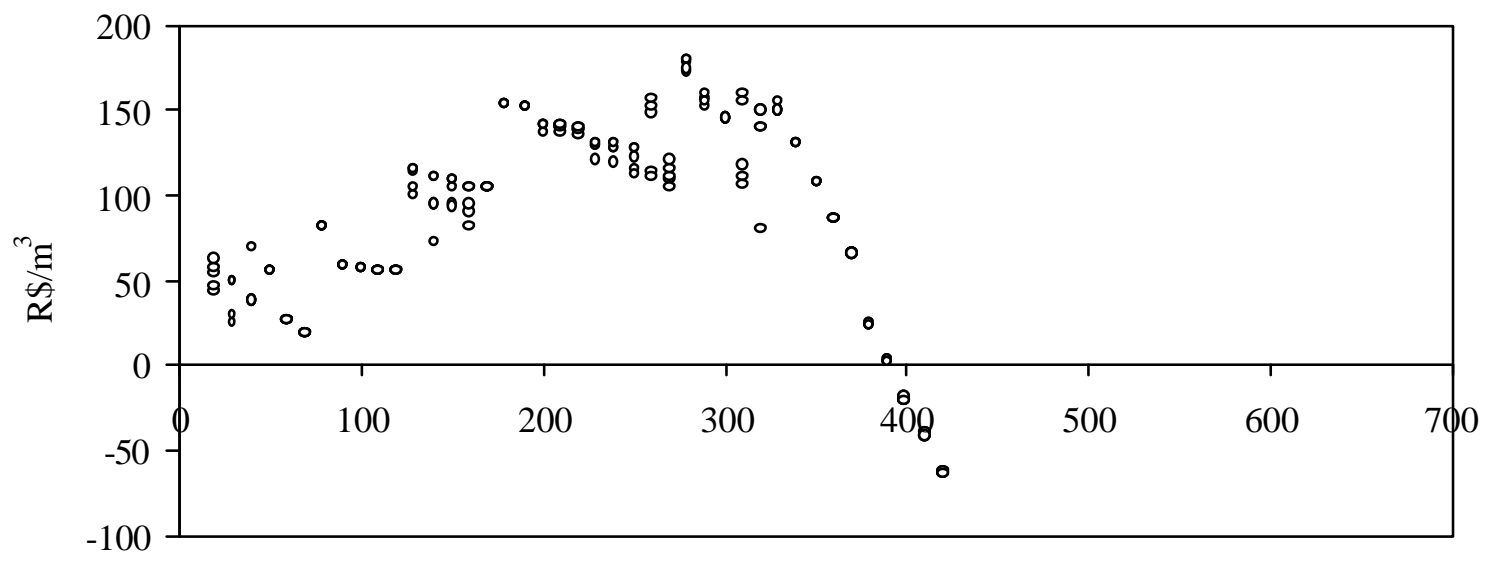

Peso Inicial (g)

- VLP

Figura 26 - Valor liquido presente (VLP) em $\mathrm{R} \$ / \mathrm{m}^{3}$ em função do tamanho unitário de entrada do alevino/juvenil.

Fonte: Dados de Pesquisa

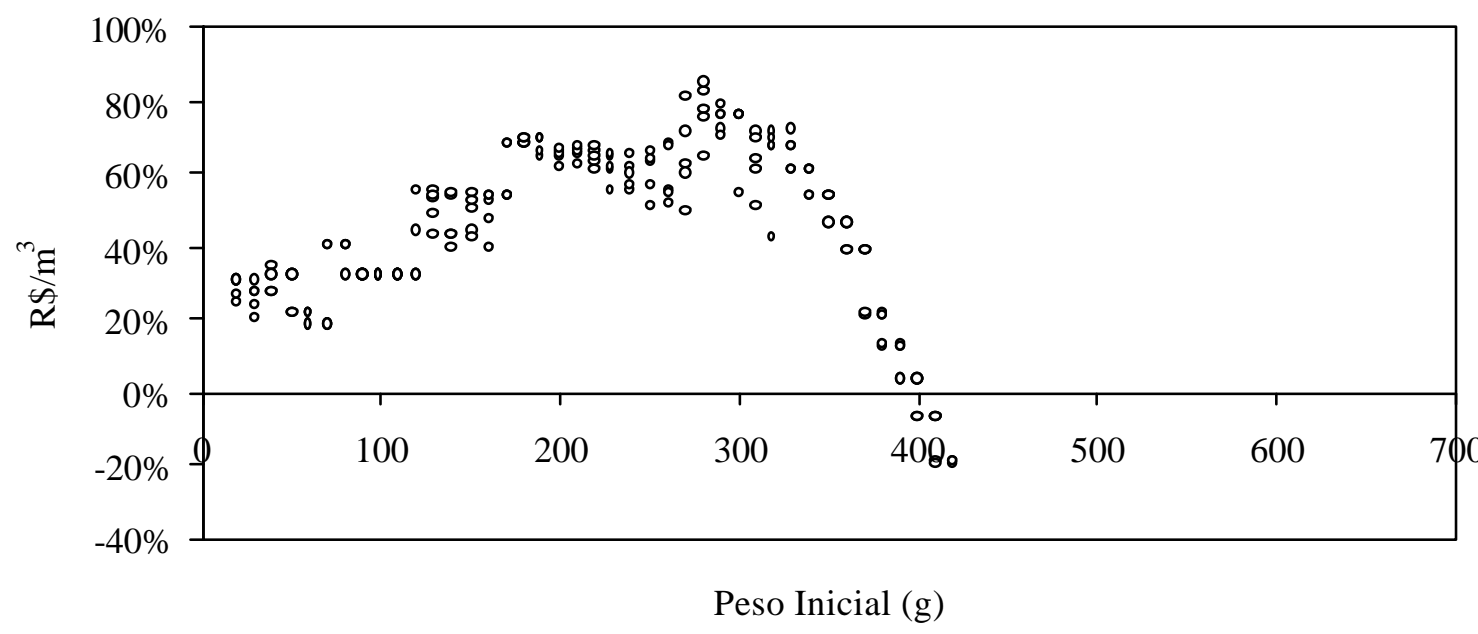

- TIR

Figura 27 - Taxa interna de retorno (TIR) em \% em função do tamanho unitário de entrada do alevino/juvenil.

Fonte: Dados de Pesquisa 
Com $20 \mathrm{~g}$ de peso inicial, os indicadores de VLP e TIR possuem valores de R\$ $42,07 / \mathrm{m}^{3}$ a $\mathrm{R} \$ 62,39 / \mathrm{m}^{3}$ e de $24,66 \%$ a $33,64 \%$, respectivamente. É importante notar que tanto para a análise do VLP quanto para TIR não considerou-se uma retirada fixa anual do investidor, sendo que a renda do mesmo foi obtida pela subtração do valor do indicador e do valor referente à taxa de desconto do projeto (12\% ao ano).

Apesar da contínua redução da rentabilidade por ciclo de produção, observou-se que num primeiro momento houve uma elevação dos índices de VLP e TIR. Ou seja, a renda gerada pela elevação do número de ciclos por vida útil do projeto mais do que compensou a redução da margem por ciclo de produção. Numa fase posterior notou-se uma tendência de queda da VLP e TIR. A renda gerada pela elevação do número de ciclos por vida útil do projeto não foi mais suficiente para compensar a redução da margem por ciclo de produção. O peso inicial que maximizou a VLP, de R $\$ 174,29 / \mathrm{m}^{3}$ a $\mathrm{R} \$ 178,78 / \mathrm{m}^{3}$, e a TIR, de $64,91 \%$ a $84,70 \%$, para esta situação foi de $280 \mathrm{~g}$.

\subsection{Análise de Sensibilidade: Simulação de Monte Carlo}

A análise de sensibilidade foi testada para uma situação em que as curvas de produção foram aferidas para um sistema de tanques-rede em represas, com área de espelho d'água entre 3,0 e 8,0 ha. Seria bastante interessante testar este modelo para situações de ambientes distintos. No entanto, as conclusões alcançadas por este modelo foram um importante indicativo de como as condições de mercados podem influenciar as tomadas de decisão técnicas e de gerenciamento do sistema de produção. As situações testadas envolveram: a comparação do sistema atual de criação com um sistema hipotético de recria; e, a comercialização de peixes vivos para pesque-pagues com uma situação de venda de filés para o mercado internacional.

As variáveis escolhidas para o processo de Simulação de Monte Carlo foram de duas categorias: técnicas e de mercado. As variáveis técnicas relacionam-se às perdas de peixes durante as diferentes fases do processo produtivo, sejam por mortalidade, fuga ou roubo. As variáveis de mercado referiram-se aos preços dos insumos e do produto final 
do processo produtivo: ração, alevino, peixe adulto. Também foram considerados variáveis de mercado o tempo gasto com a venda dos peixes adultos e reposição com alevinos, o peso de entrada do alevino/juvenil e o peso de venda dos peixes adultos.

Para a elaboração da análise de sensibilidade da rentabilidade do modelo, utilizouse a distribuição normal truncada para as variáveis selecionadas.

$$
X=N(\mu, \sigma) \rightarrow \min _{X}<X<\text { máx }_{X}
$$

Onde:

A variável $X$ segue uma distribuição de probabilidade normal com média $(\mu)$ e desvio padrão $(\sigma)$. E, X encontra-se entre um valor máximo e mínimo determinado de acordo com as pressuposições de cada variável.

\begin{tabular}{|c|c|c|}
\hline Variável (X) & $\mathrm{X}=\mathrm{N}(\mu, \sigma)$ & mín $_{\mathrm{x}}<\mathrm{X}<$ máx $_{\mathrm{x}}$ \\
\hline Peso Inicial (PI) & $\mathrm{PI}=\mathrm{N}(22,00 ; 5,50)$ & $0<\mathrm{PI}<500$ \\
\hline Peso Inicial (PI') & PI' = N (280;70) & $0<\mathrm{PI}<500$ \\
\hline Peso Final (PF) & $\mathrm{PF}=\mathrm{N}(700 ; 70)$ & $500<\mathrm{PF}<900$ \\
\hline Peso Final (PF') & $P^{\prime}=N(835 ; 65)$ & $500<\mathrm{PF}^{\prime}<900$ \\
\hline Perdas de Alevinos (P0) & $\mathrm{P} 0=\mathrm{N}(0,30 ; 0,06)$ & $0<\mathrm{P} 0<1$ \\
\hline Perdas de Alevinos (P0’) & $\mathrm{P}^{\prime}{ }^{\prime}=\mathrm{N}(0,05 ; 0,01)$ & $0<\mathrm{P}^{\prime}{ }^{\prime}<1$ \\
\hline Perdas de Adultos (P1) & $\mathrm{P} 1=\mathrm{N}(0,10 ; 0,02)$ & $0<\mathrm{P} 1<1$ \\
\hline Preço da Ração Inicial (PRI) & $\mathrm{PRI}=\mathrm{N}(0,80 ; 0,08)$ & $0,60<\mathrm{PRI}<1,00$ \\
\hline Preço da Ração Final (PRF) & $P R F=N(0,56 ; 0,06)$ & $0,48<\mathrm{PRF}<0,64$ \\
\hline Preço do Alevino (PA) & $\mathrm{PA}=\mathrm{N}(65,00 ; 13,00)$ & $45<\mathrm{PA}<85$ \\
\hline Preço de Venda (PV) & $P V=N(2,00 ; 0,20)$ & $1,80<\mathrm{PV}<2,40$ \\
\hline Preço de Venda (PV’) & $\mathrm{PV}^{\prime}=\mathrm{N}(2,50 ; 0,23)$ & $1,80<\mathrm{PV}^{\prime}<3,27$ \\
\hline Tempo paraVenda e Reposição (TVR) & $\mathrm{TVR}=\mathrm{N}(2,00 ; 0,40)$ & $1<\mathrm{TVR}<4$ \\
\hline
\end{tabular}

Quadro 5 - Variáveis e distribuições utilizadas para o processo de simulação de Monte Carlo. 
A primeira simulação comparou a situação em que inicia-se o ciclo com alevinos (PI) e vende-se os peixes com diferentes pesos (PF e PF'). Os demais parâmetros utilizados foram: P0, P1, PRI, PRF, PA, PV e TVR. Esta comparação foi pertinente uma vez que nas condições atuais de mercado os pesque-pagues têm preferido peixes de maior tamanho e não tem remunerado o produtor de acordo com o peso. Desta forma, como verificou-se na Figura 28, numa condição em que elevou-se o peso médio de venda mantendo-se as demais condições dentro da distribuição proposta, aumentou-se bruscamente a probabilidade de insucesso do empreendimento. A probabilidade de se obter uma VLP < 0 passou de 6,30 \% para 41,50 \%. A mesma tendência ocorreu com a TIR. Houve um achatamento e deslocamento para a esquerda da curva de probabilidade. Isso foi justificado pelo aumento do índice de conversão alimentar e do tempo de duração do ciclo de produção, ou seja, houve uma elevação dos custos operacionais e uma redução do número de ciclos produtivos por vida útil.

\section{$\operatorname{TIR}(\%)$}

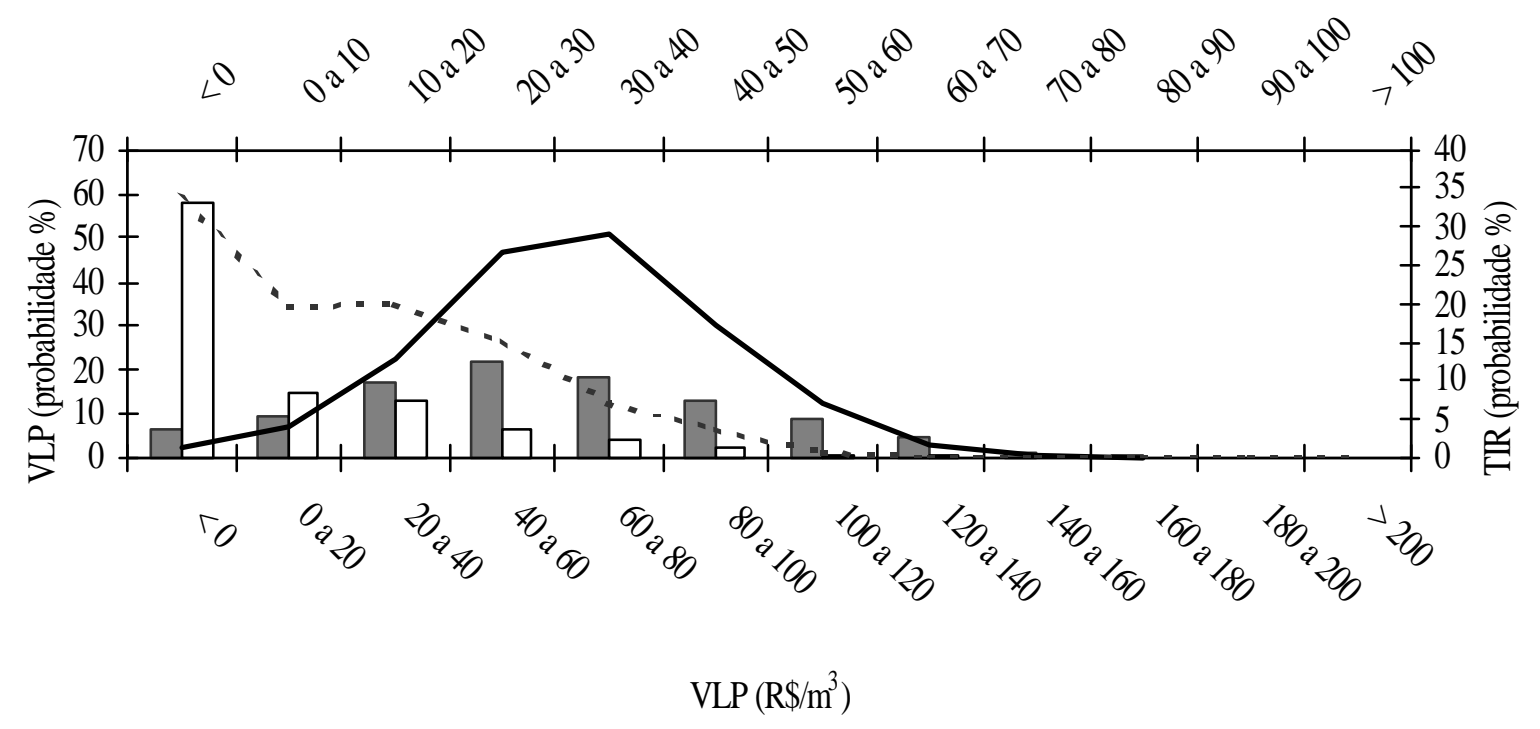

$\square \mathrm{VLP}\left(\mathrm{PF}^{\prime}\right) \square \mathrm{VLP}\left(\mathrm{PF}^{\prime \prime}\right) \longrightarrow \mathrm{TIR}\left(\mathrm{PF}^{\prime}\right)$. . . - TIR (PF")

Figura 28 - Distribuição de probabilidade da Taxa Interna de Retorno (TIR) e do Valor Líquido Presente (VLP) comparando duas médias distintas de peso final.

Fonte: Dados de Pesquisa 
Uma situação como esta, bastante desfavorável para o produtor, tem pouca probabilidade de perdurar por um período prolongado de tempo, uma vez que o produtor pode readequar o seu sistema de produção para que se atenue esta situação adversa. As medidas a serem tomadas neste caso seriam: as de curto prazo, como a busca de mercados que remunerem de acordo com tamanhos diferenciados de peixes e/ou as de longo prazo, como a redução da densidade de estocagem para o próximo ciclo. Também foi testada uma situação hipotética em que a despesca é realizada com peixes de tamanho menor. Nesta situação houve um pequeno deslocamento para a esquerda das curvas que representam os índices de rentabilidade.

A segunda simulação (Figura 29) comparou diferentes pesos de iniciais de peixes (PI e PI') para o mesmo peso de venda (PF). Os demais parâmetros utilizados foram: P0', P1, PRI, PRF, PA, PV e TVR. Esta situação representou a entrada de mais um agente no sistema de criação de peixes: o recriador. A inserção deste agente no sistema de produção pode trazer algumas vantagens para o sistema convencional de produção como: redução do tempo na fase de engorda, possibilidade de maior acúmulo de renda para o produtor, aumento do número de ciclos produtivos por vida útil do projeto e conseqüentemente uma maior produtividade do sistema. Nota-se algumas desvantagens como: a redução da margem por ciclo e a existência de um mercado que tenha liquidez para escoar tal acréscimo de produção. 
$\operatorname{TIR}(\%)$

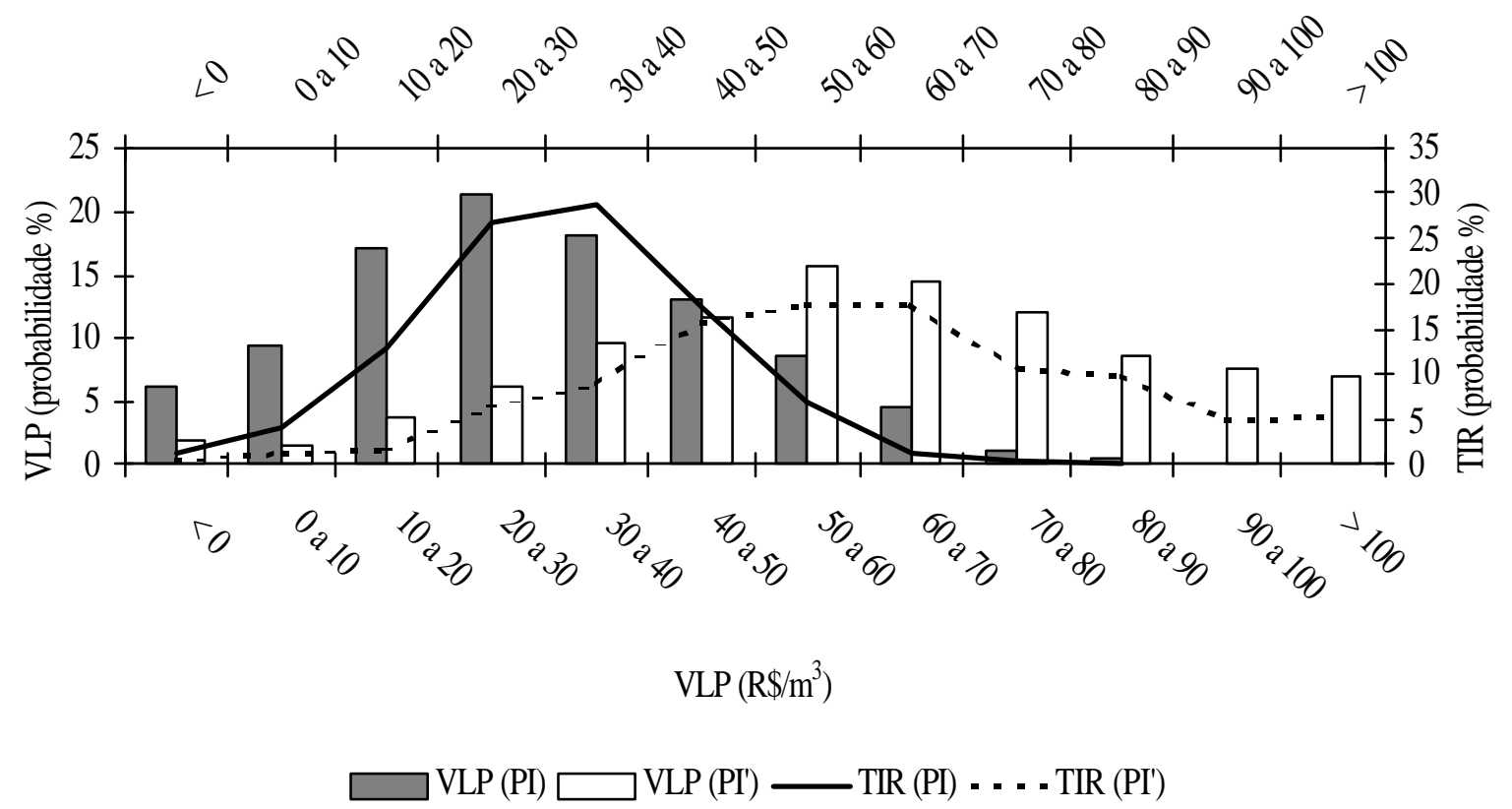

Figura 29 - Distribuição de probabilidade da Taxa Interna de Retorno (TIR) e do Valor Líquido Presente (VLP) comparando duas médias distintas de Peso Inicial (PI e PI').

Fonte: Dados de Pesquisa

Ao contrário da análise anterior, no caso da recria, observou-se que houve um deslocamento para a direita dos índices de rentabilidade quando comparados ao sistema convencional. Além de elevar a probabilidade do produtor obter ganhos mais substanciais, houve também a redução da possibilidade de insucesso. Um sistema como este, se fosse adotado nas condições de mercado atuais, provavelmente encontraria bastante dificuldade, pois o mercado de pesque-pague provavelmente não teria condição de absorver este excedente gerado aos preços vigentes no mercado. Portanto, espera-se que para um aumento de produção haja uma redução de preços pagos ao produtor. Caso esta redução seja significativa, as curvas voltariam a se deslocar para a esquerda.

Uma terceira simulação foi feita só que agora para uma outra situação de mercado. Ao invés de direcionar a produção para o mercado interno de pesca esportiva, os peixes 
serão vendidos para o mercado internacional de filés de tilápia. Para esta simulação foram utilizados os seguintes parâmetros: P0', P1, PRI, PRF e PV'. Nesta análise foi considerado o peso inicial constante de $280 \mathrm{~g}$ e o peso final de $900 \mathrm{~g}$ para atender a categoria de filé entre 5 e 7 onças (142g a 198g por filé) de peso. Preço de venda (PV') foi obtido a partir da média das duas últimas cotações de preço do filé de tilápia no mercado americano (2000 e 2001). A variação foi obtida a partir da variação do próprio preço do filé considerando a taxa de câmbio constante ( $\mathrm{R}$ \$ 2,35/US\$ cotação média de 2001). Devido ao elevado coeficiente de variação existente na população de tilápias, em torno de 17\%, foi considerado que apenas os peixes acima de $850 \mathrm{~g}$ (63\%) foram destinados à exportação, sendo os demais peixes (37\%) foram vendidos no mercado interno. $\mathrm{O}$ preço para o mercado interno seguiu a mesma variação dos peixes comercializados junto aos pesque-pagues $(\mathrm{PV})$. As restrições em relação a reposição dos peixes foram mantidas, ou seja, não houve reposição nos meses de junho, julho e agosto. As restrições de venda foram retiradas, uma vez que este mercado exige certa constância de entregas. Outro fator alterado foi o tempo de venda e reposição dos peixes que para esta análise foi considerado de 15 dias. Considerou-se a realização de despesca total dos tanques destinados ao mercado de filés. E, pelo fato da venda ser programada, o produtor tem mais tempo para organizar suas compras de alevinos e ração. Neste modelo foi considerado que o produtor responsabilizou-se por todas as fases do processo produtivo desde a compra dos insumos, passando pela produção e comercialização da produção. Considerando apenas os valores médios dos parâmetros descritos acima, obteve-se um resultado de 6 ciclos de produção num período de 5 anos, com uma margem bruta por ciclo de $\mathrm{R} \$ 31,22 / \mathrm{m}^{3}$. A VLP foi de $\mathrm{R} \$ 28,09 / \mathrm{m}^{3}$ e a TIR de $22,72 \%$. 


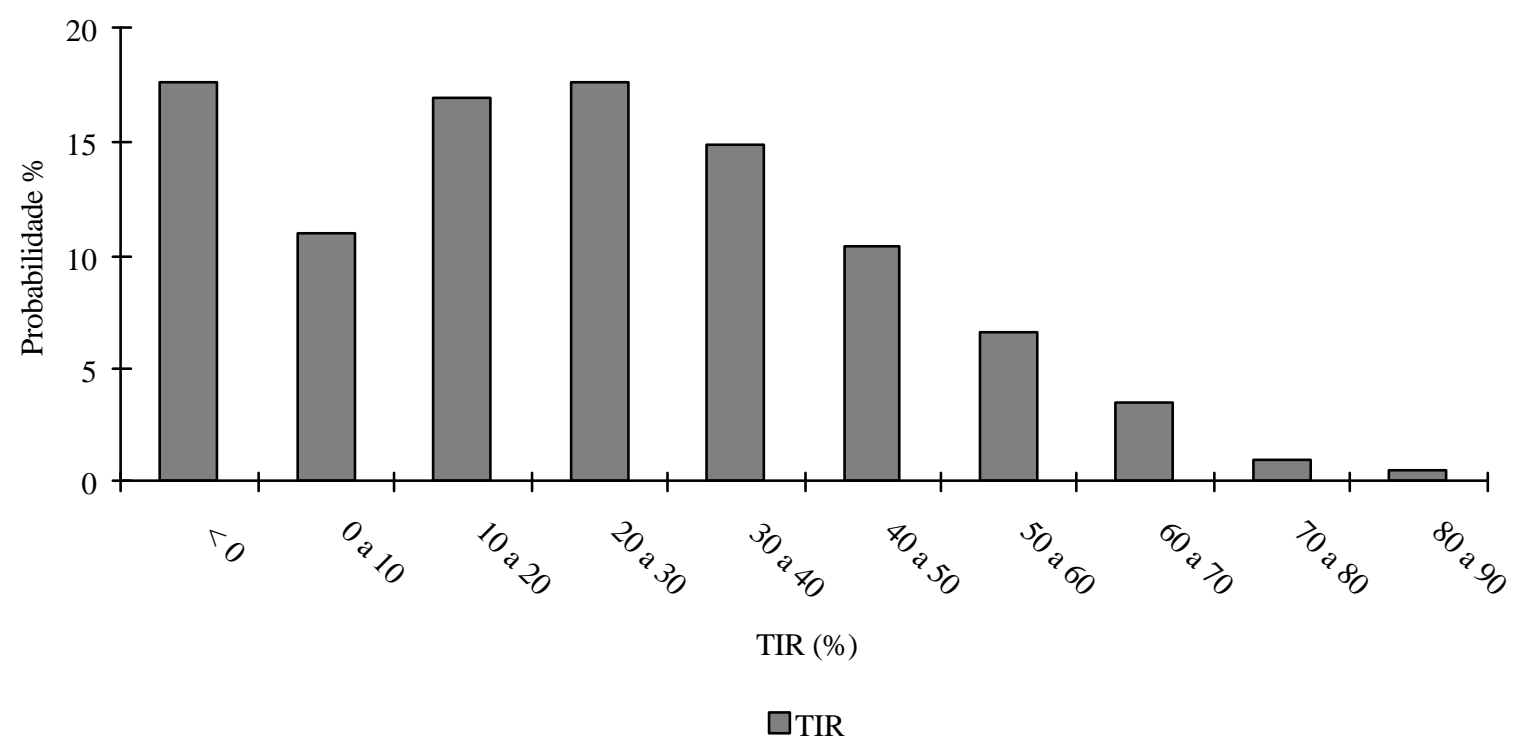

Figura 30 - Distribuição de probabilidade da Taxa Interna de Retorno (TIR) para uma situação hipotética de venda dos peixes para um sistema de exportação de filés para o produtor.

Fonte: Dados de Pesquisa

Neste caso, o risco do produtor obter um VLP menor do que zero foi de $32,77 \%$ e os valores da TIR chegaram até $90 \%$. Considerando-se uma taxa de juros de $12 \%$ ao ano, houve $32,77 \%$ de chance do projeto não conseguir se autofinanciar, porém, apresentou chances de obter uma TIR de até $90 \%$. Sendo que houve 60,34\% de chance de se obter uma TIR entre 0 e $40 \%$ (Figura 30). 


\section{CONCLUSÕES}

Este trabalho mostrou que a rentabilidade da atividade de criação de tilápia depende do peso inicial dos peixes. A determinação deste mostrou-se tão importante quanto a determinação da biomassa econômica (peso de despesca) para o cálculo de maximização de lucro ao longo da vida útil do projeto. Ao se iniciar o ciclo de produção com peixes de tamanho médio unitário mais elevados, reduziu-se o período de estocagem, porém eleva-se o custo de aquisição dos alevinos/juvenis. Este estudo chegou a conclusão que o início com peixes de peso médio de $280 \mathrm{~g}$, maximiza-se a rentabilidade durante a vida útil do projeto. $\mathrm{O}$ aumento do número de ciclos de produção mais do que compensou a redução na margem bruta até o peso médio inicial de $280 \mathrm{~g}$.

$\mathrm{Na}$ análise de riscos que considerou as vendas dos peixes para os pesque-pagues, observou-se que os riscos de insucesso do projeto foram maiores ao se despescar os peixes acima da biomassa econômica. Isto se deve principalmente a dois fatores: o ciclo produtivo foi estendido, ou seja, reduz-se o número de ciclos durante a vida útil do projeto; e, reduziu-se a margem bruta, pois o consumo de ração se elevou exponencialmente enquanto a produção tendeu a se estabilizar. Notou-se que a probabilidade de se elevar a rentabilidade do sistema aumentou quando trabalhou-se com peixes de peso médio unitário maior: peixes de $280 \mathrm{~g}$ quando comparados aos de $10 \mathrm{~g}$.

A análise de riscos que considerou o mercado norte americano de filé de tilápia como principal canal de comercialização, demonstrou que ao se iniciar o ciclo de produção com peixes de $280 \mathrm{~g}$, os riscos inerentes à produção possuem um comportamento muito semelhante ao da simulação com pesque-pagues. Lembrando que 
para o mercado internacional foi considerado um mercado com uma taxa de câmbio e liquidez constantes.

Portanto, seria adequado pensar em um sistema de recria de peixes. E até na consolidação de um novo mercado, o de peixes não terminados. Isto vai depender se a tecnologia empregada na criação desta categoria de peixes irá permitir que tanto os criadores como os compradores obtenham um aumento de rentabilidade com este tipo transação.

A partir da experiência acumulada com a confecção deste estudo foram feitas algumas sugestões para outros estudos também possam vir a colaborar com o setor de aqüicultura. Dentre as sugestões propostas estão: elaboração de mais estudos econômicos considerando sistemas de produção diferentes, como o de viveiros de terra ou de tanques-rede de maior dimensão em ambientes distintos. Estes estudos poderiam ser efetuados em diferentes regiões do país, pois assim seria possível adicionar variáveis ambientais ao modelo. Também seriam bastante pertinente trabalhos na área de melhoramento genético para as espécies que se pretendem explorar como fonte de alimento. Principalmente nos aspectos de velocidade de ganho de peso, padronização e rendimento de carcaça. Isto permitiria um melhor aproveitamento dos peixes gerando uma redução de perdas como restos de carcaça, peixes fora de tamanho entre outros. 


\section{REFERÊNCIAS BIBLIOGRÁFICAS}

ABDALLAH, P.R. Atividade pesqueira no Brasil: política e evolução. Piracicaba, 1998. 137p. Tese (Doutorado) - Escola Superior de Agricultura "Luiz de Queiroz", Universidade de São Paulo.

AMERICAN TILAPIA ASSOCIATION. Tilapia prices, imports, market and financials. http://ag.arizona.edu/azaqua/ata.html (12 May 2002)

ARAÚJO, G.C. Desenvolvimento da aquiicultura agora é responsabilidade do Ministério da Agricultura. Panorama da Aquiicultura, v.8, n.48, p.29-36, 1998.

BALARIN, J.D.; HALLER, R.D. The intensive culture of tilapia in tanks, raceways and cages. In: MUIR, J.F.; ROBERTS, R.J. (Ed.). Recent advances in aquaculture. London: Croom Helm, 1982.

BANCO NACIONAL DE DESENVOLVIMENTO ECONOMICO E SOCIAL. Comércio varejista. Rio de Janeiro: BNDES, jun. 1996. 15p.

BRASIL. Ministério do Desenvolvimento da Indústria e do Comércio Exterior. Secretaria do Comercio Exterior. Comercio exterior. http://www.mdic.gov.br (25 fev. 2001)

CARNEIRO, P.C.F.; MARTINS, M.I.E.G.;CYRINO, J.E.P. Estudo de caso da criação comercial da tilápia vermelha em tanques-redes: avaliação econômica. Informações Econômicas, v.29, n.8, p.52-61, 1999.

CHABALIN, E. Análise econômica da criação de peixes sob condições de risco: um estudo de caso do pacu. Piracicaba, 1996. 62p. Dissertação (M.S.) - Escola Superior de Agricultura "Luiz de Queiroz”, Universidade de São Paulo.

CLEMENT, S.; LOVELL, R.T. Comparison of processing yield and nutrient composition of culture Nile tilapia (Oreochromis niloticus) and channel catfish (Ictalurus punctatus). Aquaculture, v.119, p.299-310, 1994. 
CYRINO, J.E.P.; CARNEIRO, P.C.F.; BOZANO, G.L.N.; CASEIRO, A.C. Desenvolvimento da criação de peixes em tanques-rede: uma análise dos fundamentos, viabilidade e tendências, baseada em experiências bem sucedidas no Sudeste do Brasil. In: SIMPÓSIO BRASILEIRO DE AQUICULTURA, 10., Recife, 1998. Anais. v.1, p.409-433.

COELHO, S.R. de C. Situação atual e perspectivas da indústria de rações para organismos aquáticos. In: SIMPÓSIO SOBRE MANEJO E NUTRIÇÃO DE PEIXES, Piracicaba, 1997. Anais. Campinas: CBNA, 1997. p.102-116.

COLT, J.; MONTGOMERY, J.M. Aquaculture production systems. Journal of Animal Science, v.69, p.4183-4192, 1991.

FAO. Fishery Department. The state of world fisheries and aquaculture (SOFIA) 2000. Rome, 2000.

FAO. Statistics. http://www.fao.org/fi/defaut.asp (20 May 2002)

HOFFMANN, R. Elasticidades-renda das despesas com alimentos em regiões metropolitanas do Brasil em 1995-96. Informações Econômicas, v.30, n.2, p.1724, 2000.

HOFFMANN, R.; VIEIRA, S. Análise de regressão: uma introdução à econometria. 3.ed. São Paulo: Hucitec, 1998. 379p.

INSTITUTO BRASILEIRO DO MEIO AMBIENTE E DOS RECURSOS NATURAIS RENOVÁVEIS. Estatística da pesca 1999: Brasil - grandes regiões e unidades da federação. Tamandaré: IBAMA, 2000.

JOLLY, M.J.; CLONTS, H.A. Economics of aquaculture. New York: Food Products. 1993. 319p.

LOVSHIN, L.L. Tilapia farming: a growing worldwide aquaculture industry. In: SIMPÓSIO SOBRE MANEJO E NUTRIÇÃO DE PEIXES, Piracicaba, 1998. Anais. Campinas: CBNA, 1997. p.137-164.

MARANHÃO, T.C.F. Processamento e comercialização de pescado produzido em cativeiro: tilápias. In: SIMPÓSIO SOBRE MANEJO E NUTRIÇÃO DE PEIXES, Piracicaba, 1998. Anais. Campinas: CBNA, 1997. p.53-60.

MARQUES, P.V.; AGUIAR, D.R.D. Comercialização de produtos agrícolas. São Paulo: EDUSP, 1993. 295p. 
MARTIN, B.N.; SCORVO FILHO, J.D.; AYROSA, L.M.S. Custos e retornos na piscicultura em São Paulo. Informações Econômicas, v.25, n.1, p.9-47, 1995.

NORONHA, J.F. Projetos agropecuários. 2.ed. São Paulo: Atlas, 1986. 269p.

OBA, L.C.; SONODA, DY.; SHIROTA, R. Avaliação econômica de processadoras de peixes provenientes da piscicultura: processamento manual vs. mecânico. In: SIMPÓSIO SOBRE RECURSOS NATURAIS E SÓCIO-ECONÔMICOS DO PANTANAL, 3., Corumbá, 2000. Os desafios do novo milênio; resumos. Corumbá: EMBRAPA, Pantanal/UFMS, 2000. p.449.

POPMAN, T.J.; LOVSHIN, L.L. Worldwide prospects for commercial production of tilapia. Auburn: Auburn University, International Center for Aquaculture, 1996. (Research and Development Series, 41)

PROENÇA, E.C.M.; BITTENCOURT, P.R.L. Manual de piscicultura tropical. Brasília: IBAMA, 1994. 342p.

RUIVO, U.E.; POLLONIO, M.A.R. O mercado de pescado em São Paulo. Infopesca, v.5, p.20-35, 1998.

SCHIMITTOU, H.R. High density fish culture in low volume cages. Singapore: American Soybean Association, 1993. v.41, p.1993-1997.

SÃO PAULO (Estado). Secretaria da Agricultura e Abastecimento. Repensando a agricultura paulista: cadeia produtiva do pescado. São Paulo, ago. 1996. 27p.

SCORVO FILHO, J.D.; AYROSA, L.M.S. São Paulo: a situação da piscicultura no Estado. Panorama da Aqüicultura, v.35, n.6, p.18-19, 1996.

SCORVO FILHO, J.D.; MARTIN, N.B.; AYROSA, L.M.S. Piscicultura em São Paulo: custos e retornos de diferentes sistemas de produção na safra 1996/97. Informações Econômicas, v.28, n.3, p.41-60, 1998.

SCORVO FILHO, J.D.; MARTIN, N.B.; AYROSA, L.M.S. Preços na piscicultura no Estado de São Paulo, 1995 e 1997. Informações Econômicas, v.29, n.3, p.1-10, 1999.

SONODA, D.Y.; SCORVO FILHO, J.D.; SHIROTA, R.; CYRINO, J.E.P. Situação atual e perspectivas da comercialização de pescados no Estado de São Paulo. In: SIMPÓSIO SOBRE RECURSOS NATURAIS E SÓCIO-ECONÔMICOS DO PANTANAL, 3., Corumbá, 2000. Os desafios do novo milênio; resumos. Corumbá: EMBRAPA, Pantanal/UFMS, 2000. p.462. 
SONODA, D.Y.; OBA, L.C.; SHIROTA, R. Estimativa de custo de produção de tilápia em cativeiro na Região Oeste do Estado do Paraná: simulação pelo método de Monte Carlo. In: SIMPÓSIO SOBRE RECURSOS NATURAIS E SÓCIOECONÔMICOS DO PANTANAL, 3., Corumbá, 2000. Os desafios do novo milênio; resumos. Corumbá: EMBRAPA, Pantanal/UFMS, 2000. p.447.

VARIAN, H.R. Microeconomia: princípios básicos. 4.ed. Rio de Janeiro: Campus, 1990. 710p.

ZANATTA, R. Eles vieram para ficar. Anuário Pesca \& Pescado, v.2, p.21-22, 1996. 